\title{
TOWARD A FEDERAL COMMON LAW OF BANKRUPTCY: \\ JUDICIAL LAWMAKING IN A STATUTORY REGIME
}

\author{
Adam J. Levitin \\ United States Court of Appeals for the Third Circuit
}

\begin{abstract}
Bankruptcy is a statutory system, yet it is replete with practices for which there is no direct authorization in the Bankruptcy Code. This article argues that the authorization for judicial creation of bankruptcy law beyond the provisions of the Code has been misidentified as the equity powers of bankruptcy courts. This misidentification has led courts to place inappropriate statutory and historical limitations on non-Code practices because of discomfort with unguided equitable discretion.

Both the statutory and historic limitations are problematic. The statutory authorization for the bankruptcy courts' equitable powers appears to have been repealed by what one judge has called one of the clumsiest acts of Congress. The statutory section to which courts now look, 11 U.S.C. $\S 105(\mathrm{a})$, is inapplicable, and its use as a framework for evaluating non-Code practices has led to questionable decisions. Likewise, the historic limitations of the pre-Code practices doctrine are unsatisfactory and have produced contradictory Supreme Court decisions.

Instead, this article argues that non-Code practices are better thought of as a federal common law of bankruptcy. Federal common law is judge-made law that depends on precedent and judicially-devised tests rather than unpredictable discretion or rigid application of statute. Viewing non-Code practices as federal common law would lead to more predictable and consistent decisions without sacrificing the judicial flexibility necessary to facilitate corporate reorganizations.
\end{abstract}




\section{TOWARD A FEDERAL COMMON LAW OF BANKRUPTCY: \\ JUDICIAL LAWMAKING IN A STATUTORY REGIME}

by

Adam J. Levitin*

* Law clerk to the Hon. Jane R. Roth, U.S. Court of Appeals for the Third Circuit. J.D., cum laude, Harvard Law School, 2005; M.Phil., summa cum laude, Columbia University, 2001; A.M, cum laude, Columbia University, 2000; A.B., magna cum laude, Harvard College, 1998. The author would like to thank Judge Thomas Ambro, Martin Bienenstock, Judge Samuel Bufford, Michael Gadarian, Richard Levin, John F. Manning, Elizabeth Warren, and Jared Wessel for their comments and encouragement, Lesley Lawrence for her research assistance, and Sarah Levitin for her patient and understanding editing. The views expressed in this article are solely those of the author. 


\section{TOWARD A FEDERAL COMMON LAW OF BANKRUPTCY:}

JUDICIAL LAWMAKING IN A STATUTORY REGIME

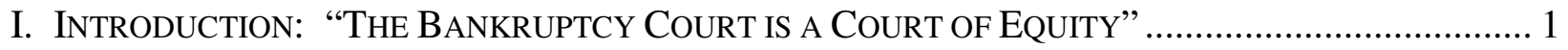

II. WHAT DOES IT MEAN TO BE A “COURT OF EQUITY”? ........................................................... 6

A. Equity Jurisdiction, Procedure, and Powers......................................................... 7

B. Doing Equity: Pepper v. Litton ............................................................................. 11

C. Balancing the Equities: NLRB v. Bildisco \& Bildisco .............................................. 14

III. JUDICIAL DISCOMFORT WITH EQUITABLE DISCRETION .................................................... 17

A. Separation of Powers Concerns .............................................................................. 17

B. "Doing Law” versus "Doing Justice" ..................................................................... 19

IV. The Limitation of BAnKRuptcy EQuity by Statutory LANGUAGE ............................. 23

A. Specific Authorizations of Equity in the Bankruptcy Code ........................................ 23

1. The Bark and the Bite of Norwest Bank Worthington v. Ahlers: How Confining Is the Code? ................................................................................................................. 24

B. Is There a General Statutory Authorization for Bankruptcy Equity Powers?............... 29

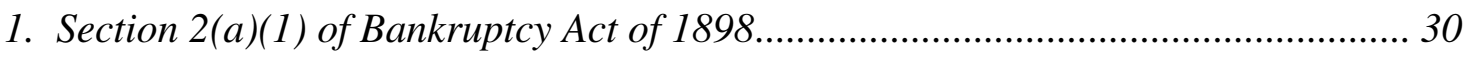

2. 12 Days of Equity? The Questionable Repeal of 28 U.S.C. $\$ 1481$......................... 32

3. Old Wine in New Vessels? 11 U.S.C. $\$ 105(a)$....................................................... 36

C. Square Pegs in Round Holes: The Problems Created by Locating Bankruptcy Equity

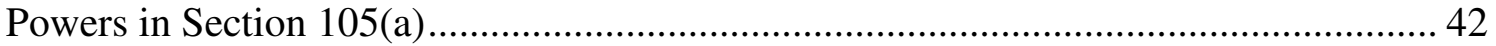

1. First Day Orders: Capital Factors, Inc. v. K-Mart Corp..................................... 43

a. Regulatory Capture and the Bankruptcy Courts?........................................... 47

b. K-Mart's Statutory Approach to the Capture Problem ................................... 51

2. Pre-Plan Payments of Pre-Petition Debts: Official Committee of Equity Security Holders v. Mabey .......................................................................................... 52

3. Division of a Limited Pot: In the Matter of Chicago, Milwaukee, St. Paul, and Pacific Railroad Corp....................................................................................... 55

4. Unraveling Authority: The Questionable Case Law Basis for a Limited Reading of Section 105(a) Powers .............................................................................................. 58

5. The Dangers of the Teleological Approach to Bankruptcy: Just For Feet............. 64

V. HiSTORICAL LIMITATIONS ON BANKRUPTCY EQUITY ................................................... 65

A. Historical Equity Powers: Grupo Mexicano de Desarrollo, S.A. v. Alliance Bond Fund,

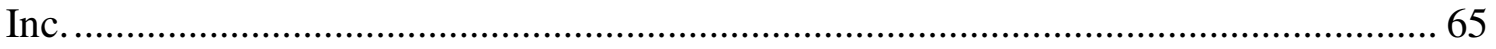

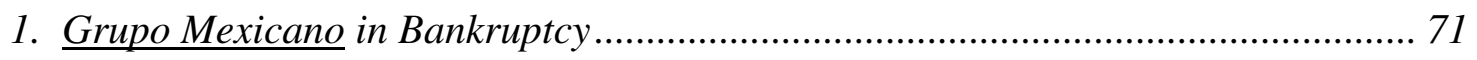

B. The Pre-Code Practices Doctrine ............................................................................ 75

1. Section 105(a) as a Source for the Pre-Code Practices Doctrine? ........................ 75

2. Development of the Pre-Code Practices Doctrine ................................................... 76

3. The Current State of the Pre-Code Practices Doctrine ......................................... 81

4. Problems with the Pre-Code Practices Doctrine ................................................. 82

(C) 2006, Adam J. Levitin 
5. Does the Pre-Code Practices Doctrine Imply a Living Federal Common Law of

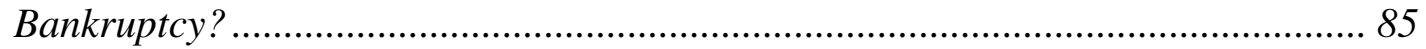

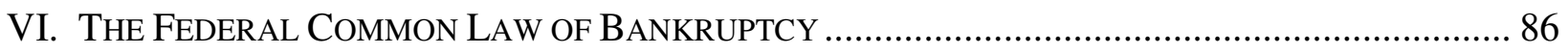

A. Can There Be a Federal Common Law of Bankruptcy? ............................................. 86

1. Defining Federal Common Law ............................................................................ 86

2. The Status of Federal Common Law Post-Erie .................................................. 87

3. Where Does Bankruptcy Fall in the Texas Industries Analysis? ............................ 88

4. Path 1: Constitutional Sources for a Federal Common Law of Bankruptcy ......... 91

5. Path 2: Statutory Sources for a Federal Common Law of Bankruptcy .................. 95

6. Explaining the Pre-Code Practices Doctrine Without Federal Common Law....... 98

B. Federal Common Law of Bankruptcy in Action ....................................................... 100

C. Reconciling Equity with a Government of Codes: Federal Common Law................ 103 


\section{INTRODUCTION: "THE BANKRUPTCY COURT IS A COURT OF EQUITY"}

A basic tenet of bankruptcy practice is that "the bankruptcy court is a court of equity." Judges and litigants regularly cite the "court of equity" maxim to justify a particular conclusion or result that lacks specific statutory authorization. ${ }^{2}$ Bankruptcy courts' equitable powers are routinely cited as the authority for common, if contested, non-Code Chapter 11 practices such as critical vendors motions (the pre-plan payment of pre-petition debts to certain suppliers of the debtor as a condition of further supply); ${ }^{3}$ substantive consolidation of separate companies that have filed for bankruptcy; ${ }^{4}$ cross-collateralization (securing pre-petition debt with pre- and postpetition collateral as part of a post-petition financing arrangement); $;^{5}$ and discharges or releases of

${ }^{1}$ E.g., Young v. United States, 535 U.S. 43, 50 (2002); Energy Res. Co., 495 U.S. 545. 549-50 (1990); Norwest Bank Worthington, v. Ahlers. 485 U.S. 197, 206 (1988); Young v. Higbee Co., 324 U.S. 204, 214 (1945); SEC v. U.S. Realty Co., 310 U.S. 434, 455 (1940); Pepper v. Litton, 308 U.S. 295, 304 (1939); Wayne United Gas Co. v. Owens-Ill. Glass Co., 300 U.S. 131, 136 (1937); Cont'l Ill. Nat'l Bank \& Trust Co. v. Chi. R. I. \& P. R. Co., 294 U.S. 648, 675 (1935); Local Loan Co. v. Hunt, 292 U.S. 234, 240-41 (1934); Bardes v. Hawarden Bank, 178 U.S. 524, 535 (1900); Ex parte, the City Bank of New Orleans (In the matter of William Christy), 44 U.S. 292. 311-313 (1845).

According to one bankruptcy judge, "the bankruptcy court is a court of equity" is the most frequently uttered substantive phrase by attorneys in her courtroom. See Marcia Krieger, "The Bankruptcy Court is a Court of Equity”: What Does that Mean? 50 S.C. L. REV. 275, 297 (1999).

${ }^{2}$ Krieger, supra note 1, at 297.

${ }^{3}$ E.g., In re Just For Feet, Inc., 242 B.R. 825-26 (D. Del. 1999); In re Ionosophere Clubs, Inc., 98 B.R. 174, 179 (Bankr. S.D.N.Y. 1989); In re Gulf Air, 112 B.R. 152, 154 (Bankr. W.D. La. 1989).

${ }^{4}$ E.g., In re Owens Corning, 419 F.3d 195 (3d Cir. 2005); In re Owens Corning, 316 B.R. 168 (Bankr. D. Del. 2004); In re Huntco, Inc., 302 B.R. 35 (Bankr. E.D. Mo. 2003); Alexander v. Compton (In re Bonham), 229 F.3d 750 (9th Cir. 2000); In re Circle Land and Cattle Corp., 213 B.R. 870 (Bankr. D. Kan. 1997); In re Standard Brands Paint Co., 154 B.R. 563 (Bankr. C.D. Cal. 1993); Eastgroup Properties v. Southern Motel Assoc., Ltd., 935 F.2d 245 (11th Cir. 1991); First Nat'l Bank of El Dorado v. Giller (In re Giller), 962 F.2d 796 (8th Cir. 1992); Union Sav. Bank v. Augie/Restivo Baking Co., Ltd. (In re Augie/Restivo Baking Co., Ltd.), 860 F.3d 515 (2d Cir. 1988); Drabkin v. Midland-Ross Corp. (In re Auto-Train Corp.), 810 F.2d 270 (D.C. Cir. 1987). See also FED. R. BANKR. P. 1015, Advisory Committee's Note ("consolidation, as distinguished from joint administration, is neither authorized nor prohibited by this rule since the propriety of consolidation depends on substantive considerations and affects the substantive rights of the creditors of different estates."). Some courts have cited 11 U.S.C. 1123(a)(5)(C) (2000) as statutory authorization for substantive consolidation. See, e.g., In re Stone \& Webster, Inc., 286 B.R. 532 (Bankr. D. Del. 2002); In re Standard Brands Paints Co., 154 B.R. 563 (Bankr. C.D. Cal. 1993).

${ }^{5}$ E.g., In re Saybrook Mfg. Co., Inc., 963 F.2d 1490, 1491 (11th Cir. 1992); Unsecured Creditors' Comm. v. First Nat'l Bank \& Trust (In re Ellingsen MacLean Oil Co.), 834 F.2d 599, 603 (6th Cir. 1987);

(C) 2006, Adam J. Levitin 
debtors' officers, directors, owners, or professionals. ${ }^{6}$

Bankruptcy, though, is a statutory system. Bankruptcy proceedings in the AngloAmerican tradition have always existed only as a matter of statute. ${ }^{7}$ The tension between the adjudicative processes implied in the "court of equity" maxim and the statutory provisions of the Bankruptcy Code exists at the heart of bankruptcy. Equity and statute are fundamentally different legal systems. The very nature of complex statutory structures is to create clear, onesize-fits-all rules that lack the fact-intensive flexibility and individualized justice of equitable discretion. $^{8}$ It is hard to reconcile equity's discretion to do substantial justice through creative remedies ex-post with a statutory regime that prescribes ex-ante precise rights and remedies. This is the fundamental struggle in bankruptcy: how to reconcile the predictable rule of law with creative, flexible, practical, individualized justice that is sometimes necessary for effective reorganizations of debtors in order to maximize value for all constituencies concerned.

Effective reorganization is the point of Chapter 11 bankruptcy law, but it is law after all, not a simple directive to fix a problem at any cost. The Bankruptcy Code involves a complex

Burchinal v. Cent. Washington Bank (In re Adams Apple, Inc.), 829 F.2d 1484, 1490 (9th Cir. 1987); Borne Chem. Co. v. Lincoln First Comm. Corp. (In re Borne Chem. Co.), 9 B.R. 263, 269-70 (Bankr. D. N.J. 1984); In re Vanguard Diversified, Inc., 31 B.R. 364, 366 (Bankr. E.D.N.Y. 1983); In re Gen. Oil Distrib., Inc., 20 B.R. 873, 876 (Bankr. E.D.N.Y. 1982); Otte v. Mfrs. Hanover Comm. Corp. (In re Texlon Corp.), 596 F.2d 1092, 1098 (2d Cir. 1979).

${ }^{6}$ See, e.g., Class 5 Nevada Claimants v. Dow Corning Corp. (In re Dow Corning Corp.), 280 F.3d 648 (6th Cir. 2002); In re Genesis Health Ventures, Inc., 266 B.R. 591 (Bankr. D. Del. 2001); In re PWS Holding Corp., 228 F.3d 224 (3d Cir. 2000); In re Cont'l Airlines, 203 F.3d 203 (3d Cir. 2000); In re Specialty Equipment Co., Inc., 3 F.3d 1043 (7th Cir. 1993); In re Drexel Burnham Lambert Group, Inc., 960 F.2d 285 (2d Cir. 1992); In re A.H. Robins Co., Inc., 880 F.2d 694 (4th Cir. 1989). But cf. In re Lowenschuss, 67 F.3d 1394 (9th Cir. 1995); In re Zale Corp., 62 F.3d 746 (5th Cir. 1995); In re Western Real Estate Fund, Inc., 922 F.2d 592 (10th Cir. 1990); Am. Hardwoods, Inc. v. Deutsche Credit Corp. (In re Am. Hardwoods, Inc., 885 F.2d 621 (9th Cir. 1989).

${ }^{7}$ Krieger, supra note 1, at 275, 277-292.

${ }^{8}$ Scarborough v. Chase Manhattan Mortgage Corp., (In re: Scarborough), No. 03-228, slip op. at 13 (E.D.Pa. Oct. 28, 2004) ("The cases relied on by the parties... set forth bright line rule tests for applying [11 U.S.C.] § 1322(b)(2)'s anti-modification provision [for mortgages on debtors' principal residences]. The problem with this is that, in an effort to create simplicity and predictability, they fail to adequately safeguard equity.") 
political balancing of debtor and creditor interests. It represents a political compromise, the terms of which should be respected, like any other piece of legislation. Yet, what sense does it make to adhere to the strictures of the Code when doing so prevents the goal of the Code from being fulfilled? The rule of law wins but a Pyrrhic victory when it defeats the purpose of the law. To fetishize the text over its meaning is dangerous, but so too is lawmaking without the prophylactic limitations of statutory text. Thus, the debate over the balance of equity and statute in bankruptcy is in some measure a debate between purposivist and textualist methods of statutory interpretation. ${ }^{9}$ The struggle between equity and statute is reflected throughout the case law on the authorization of non-Code practices and throughout the academic literature on bankruptcy. ${ }^{10}$ So how can equity be reconciled with a Code-based legal system like bankruptcy ${ }^{11}$

This article argues that because American courts are uncomfortable with unguided equitable discretion, they have tried to limit their equitable powers to those authorized by statute or grandfathered in under the pre-Code practices doctrine. These limitations are problematic both conceptually and in terms of the results they produce. Although there was once statutory authorization for bankruptcy courts' equitable powers, the relevant statutory section appears to have been repealed. The statutory section to which courts now look for the authorization of bankruptcy equity powers, 11 U.S.C. $\S 105(a)$, is inapplicable, and its use as an analytical framework for evaluating non-Code practices has led to questionable decisions. Likewise, the pre-Code practices doctrine is an unsatisfactory limitation on non-Code practices that has

\footnotetext{
${ }^{9}$ See John F. Manning, Textualism and the Equity of the Statute, 101 ColuM. L. REV. 1, 5 (2001).

${ }^{10}$ Douglas G. Baird, Bankruptcy's Uncontested Axioms, 108 YALE L.J. 573, 574-580 (1998). See also Elizabeth Warren, Bankruptcy Policy, 54 U. CHI. L. REV. 775 (1987).

${ }^{11}$ The question of how bankruptcy equity powers interact with non-Code law, such as state law, is beyond the scope of this article. See Thomas E. Plank, The Erie Doctrine and Bankruptcy, 79 Notre DAME L. REV. 633 (2004); Alfred Hill, the Erie Doctrine in Bankruptcy, 66 HARV. L. REV. 1013 (1953). See also Butner v. United States, 440 U.S. 48 (1979).
} 
produced contradictory decisions from the Supreme Court and is incapable of recognizing modern analogs to pre-Code practices.

Judging always involves some measure of discretion; the question is how that discretion is to be channeled. Instead of attempting to reconcile equity and statute through inapplicable statutory or historical constraints, this article proposes using federal common law as an alternative framework for analyzing non-Code practices. Federal common law is judge-made law that depends on precedent and judicially-devised tests rather than unpredictable discretion or rigid application of statute. Federal common law allows for the development of bankruptcy law outside the Code, but its constraints of precedent and judge-made tests allow for predictable and consistent judgments. Federal common lawmaking has long quietly existed in bankruptcy, but it has been a clunking sort of common lawmaking because it has never been recognized as such. Instead, it has always been analyzed in terms of equity, which has led to the inappropriate statutory and historical limitations.

It is unclear at present whether federal courts have common lawmaking powers in bankruptcy. The Supreme Court has never addressed the issue and the few circuits that have are split. This article argues that federal courts do have such a power because of the uniquely federal interest in bankruptcy due to the uniformity requirement of the Bankruptcy Clause of the Constitution, ${ }^{12}$ as implied by the Supreme Court's recent bankruptcy sovereign immunity decision in Central Virginia Community College v. Katz. ${ }^{13}$ This article further argues that federal common lawmaking is proper in bankruptcy because there is an implicit Congressional authorization of common lawmaking power in the Bankruptcy Code, as indicated by its legislative history and Congressional and judicial ratification of common lawmaking powers.

${ }^{12}$ U.S. CONST. art. I, § 8, cl. 4.

${ }^{13} 546$ U.S. _ (2006), No. 04-885, slip op. (Jan. 23, 2006).

(C) 2006, Adam J. Levitin 
Finally, this article demonstrates that analysis of non-Code practices as part of a federal common law of bankruptcy strikes a balance between the needs for flexibility and for the predictable rule of law and would result in more sensible rulings on non-Code practices.

In arguing for a federal common law approach to bankruptcy, this article also attempts to stake out a middle ground between the two major camps in bankruptcy scholarship, which Douglas G. Baird has termed "traditionalists" and "proceduralists", ${ }^{14}$ but which might better be termed "practicalists" and "proceduralists." Practicalists, who have what might be called a more "liberal" view of bankruptcy, believe that "bankruptcy law plays a special role in our legal system and advances substantive goals that are both important and distinctive." ${ }^{\prime 15}$ They emphasize rehabilitation of debtors ${ }^{16}$ and, in the Holmesian tradition, emphasize the factual individuality of each case. ${ }^{17}$ Therefore, they believe that bankruptcy judges must have broad discretion and powers to implement bankruptcy policy. ${ }^{18}$ Bankruptcy law must be flexible enough to carry out its underlying policies.

Proceduralists, on the other hand, do not see bankruptcy as at all special or different from other legal regime. They favor clear rules and rule of law over judicial flexibility and discretion. They also tend to associate with the conservative law-and-economics school of legal thought. Proceduralists do not see the survival of the debtor as an independent good $^{19}$ and emphasize that firms must "live or die in the market." 20 Instead, they are generally concerned with the ex-ante

14 Baird, supra note 10, at 574-580; Warren, supra note 10. Such a binary divide obviously oversimplifies the complexity and nuance of bankruptcy scholarship, as Professor Baird acknowledges, supra note 10 , at 576 , but it is also a useful characterization of the field.

${ }^{15}$ Baird, supra note 10, at 576.

${ }^{16} \mathrm{Id}$. at 577.

${ }^{17} \mathrm{Id}$. at 579 .

${ }^{18} I d$.

${ }^{19} I d$. at $579-80$.

${ }^{20} I d$. at 578 . 
incentive-setting effects of clear legal rules on creating efficient markets. ${ }^{21}$ Accordingly, proceduralists believe that the bankruptcy judge should play a more passive role and exercise less discretion. ${ }^{22}$

Non-Code practices, usually authorized under the rubric of bankruptcy equity, are a particular flash point for these scholarly camps. For practicalists, non-Code practices represent the flexibility and realism of the bankruptcy courts at their best, while for proceduralists, nonCode practices represent unnecessary, overreaching, and even harmful displays of judicial discretion and activism. ${ }^{23}$ In particular, the traditional analysis of non-Code practices through the lens of equity has only sharpened these divisions, as equity has become the byword for the creation of non-statutory rights in bankruptcy. A federal common law approach to non-Code practices strikes a middle ground between the practicalist concerns of individualized justice and proceduralist concerns about rule of law.

This article begins with a consideration of what "a court of equity" might mean in the bankruptcy context. It then turns to the problems of discretion within the American judicial system. Next, it examines the two principle ways in which courts have attempted to limit equitable discretion — statutory authorization and historical practice — and the problems with each method, both conceptually and in terms of results. The article then considers whether federal common lawmaking is possible in bankruptcy, and concluding that it is, appraises the advantages to such an analytical framework for non-Code practices.

\section{WHAT DOES IT MEAN TO BE A "COURT OF EQUITY"?}

\footnotetext{
${ }^{21} \mathrm{Id}$. at 580 .

${ }^{22} I d$. at $579-80$.

${ }^{23}$ Alan M. Ahart, The Limited Scope of Implied Powers of a Bankruptcy Judge: A Statutory Court of Bankruptcy, Not a Court of Equity, 79 AM. BANKR. L.J. 1, 37-39 (2005).
} 


\section{A. Equity JuRisdiction, Procedure, AND PoWERS}

The term "equity" is particularly confusing in bankruptcy because of its multiple meanings. Depending on context, "equity" refers to jurisdiction, procedures, court powers, justice, an ownership interest, or type of right. The last two of these meanings are distinct, and their use is readily discernable from context. The first four meanings, however, have often been confused and conflated in the description of bankruptcy courts as "courts of equity."

Surprisingly, the origins of the "court of equity" maxim are unknown. No reported case has considered the history of the maxim, and only two articles, by Bankruptcy Judges Marcia Krieger and Alan Ahart respectively, have addressed the meaning and history of the "court of equity" maxim. ${ }^{24}$ Neither Krieger nor Ahart pinpoints an origin for the "court of equity" maxim. Instead, they argue that the designation is purely a judicial creation. ${ }^{25}$ The earliest reported use of the phrase "the bankruptcy court is a court of equity" is from $1876,{ }^{26}$ but cases going back as far as 1842 use similar language, ${ }^{27}$ and the Bankruptcy Act of 1841 provided that district courts' jurisdiction in proceedings in bankruptcy was "to be exercised summarily, in the nature of summary proceedings in equity."28

Krieger and Ahart both conclude that 19th and early 20th century references to bankruptcy

\footnotetext{
${ }^{24}$ Krieger, supra note 1; Ahart, supra note 23.

${ }^{25}$ Krieger, supra note 1, at 301; Ahart, supra note 23, at 18.

${ }^{26}$ In re Moller, 1876 U.S. Dist. LEXIS 191, at *4 (S.D.N.Y. 1876) (“A court of bankruptcy is a court of equity.").

${ }^{27}$ Ex Parte Foster, 9 F. Cas. 508; 1842 U.S. App. LeXIS 600 (C.C.D. Mass. 1842) (Story, J.) ("I lay it down as a general principle that the district court is possessed of the full jurisdiction of a court of equity over the whole subject matters which may arise in bankruptcy, and is authorized by summary proceedings to administer all that relief which a court of equity could administer, under the like circumstances, upon a regular bin and regular proceedings, instituted by competent parties.") (emphasis added); Ayer v. Brastow, 2 F. Cas. 263, 265, 1842 U.S. Dist. LEXIS 27, at*7-*8 (D. Maine 1842) ("The proceedings in bankruptcy are according to the course of equity, and to enable the court to do full justice to all partners in interest, the district court, sitting as a court of bankruptcy, is clothed with all the powers of a court of general equity jurisdiction.") (emphasis added).

${ }^{28} 27$ Cong. Sess. 1, Ch. 9, 5 Stat. 440. 445, §6 (1841) (emphasis added). repealed Mar. 3, 1843, Ch. 82, 5 Stat. 614.
} 
courts as courts of equity dealt only with questions of procedure and the distinction between the original (or summary) and plenary jurisdiction of district courts sitting in bankruptcy, a distinction similar to the current divide between core and adversary proceedings in bankruptcy. ${ }^{29}$ As Krieger noted, "[r]eferences to the bankruptcy court as a court of equity were most often used in a technical context to define the scope of exclusive or original bankruptcy jurisdiction."30 Broader characterizations of bankruptcy courts as courts of equity, according to Krieger and Ahart, are the result of later judicial misreading of dicta in these early cases. ${ }^{31}$

Nonetheless, a significant number of early cases indicate that bankruptcy equity is more than procedural or jurisdictional. These cases indicate that at the very least bankruptcy courts exercised the powers of courts of equity, particularly the injunction. ${ }^{32}$ Indeed, the 1841 and 1867

${ }^{29}$ Krieger, supra note 1, at 298-301. See also Northern Pipeline Constr, Co. v Marathon Pipe Line Co., 458 U.S. 50, 53 (1982) (explaining difference between summary and plenary jurisdiction in bankruptcy).

${ }^{30}$ Krieger, supra note 1, at 298.

${ }^{31}$ Id. at 298-301; Ahart, supra note 23, at 18.

${ }^{32}$ See, e.g., In re Ohio Copper Mining Co., 241 F. 711, 713 (S.D.N.Y. 1917) ("The bankruptcy court is a court of equity, armed with equity powers in aid of its jurisdiction and the enforcement of its orders."); In re Swofford Bros. Dry Goods Co., 180 F. 549, 553 (W.D. Mo. 1910) ("A proceeding in bankruptcy is a proceeding in equity, and, for the purposes of enforcing and protecting its jurisdiction, a court of bankruptcy has all the inherent powers of a court of equity."); United States v. Liberman, 176 F. 161, 162 (C.C.E.D.N.Y, 1910) ("under the powers of a court of bankruptcy as a court of equity"); In re Hicks, 133 F. 739, 746 (N.D.N.Y. 1905) ("The power to enjoin is inherent in the court of bankruptcy, as a court of equity."); In re Siegel-Hillman Dry Goods Co., 111 Fed. 980, 983 (E.D. Mo. 1901) (“This court, sitting in bankruptcy, can exercise the full powers of a court in equity for the ascertainment and enforcement of the rights and equities of the various parties interested in the estate of the bankrupt company."); Ex Parte Norwood, 18 F.Cas. 452, 455 (D. Ill. 1873) ("The bankruptcy law clothes the district courts, sitting as courts of bankruptcy, with all the powers of courts of equity."); In re Mallory, 1871 U.S. Dist. LEXIS 223, at *6 (D. Nev. 1871) ("Now, when congress delegated to the district courts, this equitable jurisdiction in bankruptcy, it must follow, by necessary implication, that it also delegated at the same time the power to administer such remedies known to the law as were absolutely indispensable to the complete exercise of the jurisdiction expressly conferred."); Ayer v. Brastow, 1842 U.S. Dist. LEXIS 27, at *7-*8 (D. Maine 1842) ("The proceedings in bankruptcy are according to the course of equity, and to enable the court to do full justice to all partners in interest, the district court, sitting as a court of bankruptcy, is clothed with all the powers of a court of general equity jurisdiction."); Ex Parte Foster, 9 F. Cas. 508; 1842 U.S. App. LEXIS 600 (C.C.D. Mass. 1842) (Story, J. on circuit) ("I lay it down as a general principle that the district court is possessed of the full jurisdiction of a court of equity over the whole subject matters which may arise in bankruptcy, and is authorized by summary proceedings to administer all that relief which a court of equity could administer, under the like circumstances, upon a regular bin and regular proceedings, instituted by competent parties."). 
Bankruptcy Acts specifically gave bankruptcy courts enforcement powers equal to those of the circuit courts sitting in equity. ${ }^{33}$

Under the 1978 Code, bankruptcy courts arguably exercise equity powers through the All-Writs Act, ${ }^{34} 11$ U.S.C. § 105(a), and 28 U.S.C. § 1481. Moreover, the 1978 Code incorporated many of the principles and rules of equity jurisprudence in statutory form, albeit through the filter of earlier Bankruptcy Acts. For example, the automatic stay ${ }^{35}$ and the discharge ${ }^{36}$ incorporate the injunction. The strong-arm power of the trustee, ${ }^{37}$ the Code's broad definition of the estate, ${ }^{38}$ and the very nature of bankruptcy proceedings as involving multiple parties attempting to recover from a limited fund effectuate the marshalling of assets. The requirement of timely filing of claims bears the imprint of the doctrine of laches. ${ }^{39}$ The treatment of the estate as a trust invokes the equitable corpus of the trust. The Code has incorporated fraud actions, a hallmark of equity jurisprudence, as voidable preferences ${ }^{40}$ and fraudulent conveyances. ${ }^{41}$ Equitable subordination ${ }^{42}$ of claims is, of course, equitable, deriving from the "clean hands" maxim. Core bankruptcy proceedings (as opposed to adversary proceedings) are also less formal and more summary in nature than trials at law. ${ }^{43}$ Indeed, the

${ }^{33}$ Act of Mar. 2, 1867, 39 Cong. Sess 2, Ch. 176, 14, 14 Stat. 517, 518 (repealed 1878); Act of Aug. 19, 1841, 27 Cong. Sess. 1, Ch. 9, 5 Stat. 440, 445 (repealed Mar. 3, 1843) (Bankruptcy courts shall have "full authority and jurisdiction to compel obedience to all orders and decrees passed by them in bankruptcy, by process of contempt and other remedial process, to the same extent the circuit courts may now do in any suit pending therein in equity.").

${ }^{34} 28$ U.S.C. $\$ 1651(2000)$.

3511 U.S.C. $\$ 362(2000)$.

${ }^{36} 11$ U.S.C. $\$ 524(\mathrm{a})(2000)$.

${ }^{37} 11$ U.S.C. $\$ 544$ (2000).

${ }^{38} 11$ U.S.C. $\$ 541(2000)$.

${ }^{39} 11$ U.S.C. $\$ 502(\mathrm{~b})(9)(2000)$.

${ }^{40} 11$ U.S.C. $\$ 547$ (2000).

${ }^{41} 11$ U.S.C. $\$ 548(2000)$.

4211 U.S.C. $\$ 510$ (b) (2000).

${ }^{43}$ This informality of procedure is still preserved in the equity courts of the few states, like the Delaware Chancery Court, that have not merged law and equity into a unity court. 
priority scheme of the $\operatorname{Code}^{44}$ is an implementation of the equity maxim that "equity is equality" 45 -like creditors are to be treated alike. Many of the statutory powers of bankruptcy courts are themselves derived from equity powers.

Moreover, even to the extent that the "court of equity" designation contains a procedural element, it cannot be divorced from the substantive component. While bankruptcy proceedings historically had a more summary nature than trials at law, they have never been governed by Equity Rules, ${ }^{46}$ but by their own rules of procedure. ${ }^{47}$ The summary nature of equity proceedings is in keeping with equity's emphasis on substance over form and the pursuit of justice over technical requirements. ${ }^{48}$ Thus, being a "court of equity" is a procedural designation only in indicating the bankruptcy proceedings are not bound by the procedures of a court of law.

Courts have often seen bankruptcy equity affecting not just jurisdiction or enforcement of orders, but also rules of decision and dictating how courts should apply their equitable powers. ${ }^{49}$ Historically, this often meant that the court looked beyond technical requirements to substantive justice, particularly regarding pleadings, respected substance over form, ${ }^{50}$ or balanced competing

\footnotetext{
${ }^{44} 11$ U.S.C. $\$ 507$ (2000).

${ }^{45}$ This maxim is often presented in its Latin form, aquitas est aqualitas.

4620 U.S. (7 Wheat.) v (1822); 42 U.S. (1 How.) xli (1842); Equity Rules of 1912, 226 U.S. 627-673 (1913); 38 Stat. 956 (Law and Equity Act of 1915).

${ }^{47}$ See Bankruptcy Act of 1898, 55 Cong. 2d Sess., Ch. 541, 30 Stat. 544 (1898) (codified at 11 U.S.C. $\S \S$ 18-32 (repealed 1978)).

48 See Edward D. Re AND Joseph R. Re, Remedies 30 (5th Ed. 2000) ("Equity Regards Substance Rather than Form."). C $f$. Richard Francis' Maxims of Equity (1726) quoted in PETER CHARLES HOFFER, The LAW's CONSCIENCE: EQUiTABle CONSTITUTIONALiSM IN AMERICA (1990), 11-12 (“[E]quity regards not the circumstance, but the substance of the act.").

${ }^{49}$ E.g., Larson v. First State Bank of Vienna (In re Eggen), 21 F.2d 936, 938 (8th Cir. 1927) ("A court of bankruptcy is a court of equity, and its judicial officers, its judge and its referee in bankruptcy, in deciding and adjudging the rights and duties of parties entitled to their decision, are governed by the principles and rules of equity jurisprudence."); In re Siegel-Hillman Dry Goods Co., 111 Fed. 980, 983 (E.D. Mo. 1901) ("This court, sitting in bankruptcy, can exercise the full powers of a court in equity for the ascertainment and enforcement of the rights and equities of the various parties interested in the estate of the bankrupt company.").

${ }^{50}$ E.g., In re Kane, 127 F. 552, 553 (7th Cir. 1904) (“A court of bankruptcy is a court of equity, seeking to administer the law according to its spirit, and not merely by its letter."); Swarts v. Siegel, 117 Fed. 13, 16
}

(C) 2006, Adam J. Levitin 
equities. ${ }^{51}$ The designation of bankruptcy courts as "courts of equity" is an indication not only of bankruptcy courts' powers, but also of a manner of decision-making that involves a considerable exercise of discretion.

\section{B. DOING EQUITY: PEPPER V. LITTON}

The elements of equity jurisdiction, equity principles and rules, equitable administration, substance over form, waiving of technical requirements, and substantial justice coalesced in Pepper v. Litton, the Supreme Court's most extensive discussion about what it means to be a “court of equity." Writing for a unanimous Court, Justice Douglas declared:

Courts of bankruptcy are constituted by $\S \S 1$ and 2 of the Bankruptcy Act [of 1898] (30 Stat. 544) and by the latter section are invested "with such jurisdiction at law and in equity as will enable them to exercise original jurisdiction in bankruptcy proceedings." Consequently this Court has held that for many purposes "courts of bankruptcy are essentially courts of equity, and their proceedings inherently proceedings in equity." Local Loan Co. v. Hunt, 292 U.S. 234, 240 (1934). By virtue of $\$ 2[$,$] a bankruptcy court is a court of equity at least$ in the sense that in the exercise of the jurisdiction conferred upon it by the Act, it applies the principles and rules of equity jurisprudence. Among the granted powers are the allowance and disallowance of claims; the collection and distribution of the estates of bankrupts and the determination of controversies in relation thereto; the rejection in whole or in part "according to the equities of the case" of claims previously allowed; and the entering of such judgments "as may be necessary for the enforcement of the provisions" of the Act. In such respects the jurisdiction of the bankruptcy court is exclusive of all other courts. [Citation omitted.]

The bankruptcy courts have exercised these equitable powers in passing on a wide range of problems arising out of the administration of bankrupt estates. They have been invoked to the end that fraud will not prevail, that substance will not give way to form, that technical considerations will not prevent substantial justice

(8th Cir. 1902) ("In equity, and in bankruptcy, which is a branch of equity, names and forms are unimportant where the truth is evident.").

${ }^{51}$ E.g., In re Lahongrais, 5 F.2d 899, 901 (D. Nev. 1871) ("Furthermore a court of bankruptcy is a court of equity, and has jurisdiction as such court to set aside an allowance made as an administration expense, when it appears that it was procured through fraud, or that the amount allowed was so grossly excessive as to be tantamount thereto."); Ayer v. Brastow, 1842 U.S. Dist. LEXIS 27, at *7-*8 (D. Maine 1842) ("The proceedings in bankruptcy are according to the course of equity, and to enable the court to do full justice to all partners in interest, the district court, sitting as a court of bankruptcy, is clothed with all the powers of a court of general equity jurisdiction.").

(C) 2006, Adam J. Levitin 
from being done. ${ }^{52}$

Pepper v. Litton emphasized the application of principles and rules of equity jurisprudence, rather than equity procedure. It also emphasized that these principles were to be applied to achieve substantial justice that was not limited by technical considerations and forms. Whatever it might have meant in the 19th century for a bankruptcy court to be a "court of equity," it has been an unchallenged axiom of bankruptcy law since Pepper $v$. Litton that bankruptcy courts are to apply bankruptcy law in accordance with the principles and rules of equity jurisprudence.

When Congress enacted the Bankruptcy Code in 1978, it did so with Pepper v. Litton in mind. The legislative history of the Code shows that Congress thought of bankruptcy equity existing in a substantive, not merely procedural, sense. The House Report on the Bankruptcy Act of 1978 emphasized that "[t]he bankruptcy court will remain a court of equity." 53 The House Report made this comment in the context of an explanation of a substantive, not procedural equity component of the Code, section 510(b), which allows for equitable subordination of claims. Equitable subordination is a procedure in which a creditor's claim on the bankruptcy estate is assigned lower priority than other claims on the estate because of some improper or inequitable behavior by the creditor. Equitable subordination matters when the estate's assets are inadequate to cover all creditors' claims, as an equitably subordinated creditor's recovery will be limited. The House Report observed that section 510(b) was intended to codify Pepper v. Litton and that "[t]he court's power is broader than the general doctrine of

\footnotetext{
52308 U.S. at 304-305.

${ }^{53}$ H.R. REP. NO. 95-595, at 359 (1977), reprinted in U.S.C.C.A.N. 5963, 6315 ("This section[, proposed 11 U.S.C. 510(b),] is intended to codify case law, such as Pepper v. Litton, 308 U.S. 295 (1939) and Taylor v. Standard Gas and Electric Co., 306 U.S. 295 (1939) and is not intended to limit the [bankruptcy] court's power in any way. The bankruptcy court will remain a court of equity, proposed 28 U.S.C. 1481; Local Loan v. Hunt, 292 U.S. 234, 240 (1934).”).
}

(C) 2006, Adam J. Levitin 
equitable subordination, and encompasses subordination on any equitable grounds."54 The legislative history also cited proposed 28 U.S.C. $§ 1481$ as enacting this proposition. ${ }^{55}$

From the legislative history, then, one could read Congress's codification ${ }^{56}$ of Pepper $v$. Litton in section 510(b) of the $\operatorname{Code}^{57}$ as allowing for substantive equity, but only in a particular situation, rather than providing a general guideline for decision-making throughout the Code. If this were the case, however, it would seem odd to emphasize that the bankruptcy court would "remain a court of equity" merely by virtue of the power of equitable subordination, a single tool in equity's toolbox, rather than a panoply of equity powers, especially as Pepper v. Litton made clear that bankruptcy equity is about a larger jurisprudential ethos of "substantial justice." Exactly what that ethos means, though, was not spelled out in Pepper v. Litton.

Pepper v. Litton's discussion of equity was painted in broad strokes. It also involved a very clear-cut set of facts pointing to inequitable behavior by the debtor. The debtor corporation and its sole shareholder were in cahoots in a "planned and fraudulent scheme."58 Although complex, the "scheme followed an ancient pattern" with the aim of "defraud[ing] creditors [in a manner] reminiscent of some of the evils with which 13 Eliz. C. 5 was designed to cope."59 The sole shareholder secured a sham default judgment against the debtor corporation for back wages in order to outmaneuver an adverse judgment in a creditor. ${ }^{60}$ Then, through a series of corporate transfers, the sole shareholder arranged for the judgment creditor to be the only general unsecured claim in bankruptcy against the debtor corporation, which conveniently had sufficient

\footnotetext{
${ }^{54}$ H.R. REP. NO. 95-595, at 359 (1977), reprinted in U.S.C.C.A.N. 5963, 6315.

${ }^{55} I d$.

${ }^{56} \mathrm{Id}$.

${ }^{57} 11$ U.S.C. § 510(b) (2000).

58308 U.S. at 298.

${ }^{59}$ Id. at 296-297. 13 Eliz. C. 5 (1571), often called "The Statute of Elizabeth," was the first English fraudulent conveyances statute.

${ }^{60} 308$ U.S. at 297-298.
}

(C) 2006, Adam J. Levitin 
assets to pay off only the others creditors, including the shareholder's sham default judgment. ${ }^{61}$ Bankruptcy relief was being sought inequitably to avoid the claims of one creditor. ${ }^{62}$

Because Pepper dealt with such an obvious abuse of process, it is not particularly instructive about how to resolve cases in which the equities are not so clear-cut. Pepper speaks in generic terms of "substantial justice" triumphing over "technical considerations." Just how far can that go as a principle guiding decisions? Is the power to pursue "substantial justice" the power to ignore the explicit provisions set forth by Congress as "technical considerations"? Equity jurisprudence is necessarily one of discretion; equitable relief is never mandatory. However broad a bankruptcy court's discretion might be, it is clearly not absolute. ${ }^{63}$ The next sections probe the limits of that discretion.

\section{BALANCING THE EQUITIES: NLRB V. BILDISCO \& BILDISCO}

$N L R B$ v. Bildisco \& Bildisco ${ }^{64}$ contains the Supreme Court's most extensive discussion of what it means for a bankruptcy court to be a "court of equity." Bildisco dealt with the question of under what conditions a bankruptcy court could permit a debtor-in-possession to reject a collective bargaining agreement. The Court held that collective-bargaining agreements subject to the National Labor Relations Act $^{65}$ were covered by the assumption/rejection provisions for executory contracts contained in section 365 of the Bankruptcy Code. ${ }^{66}$

\footnotetext{
${ }^{61} I d$. at 298-302.

${ }^{62}$ Cf. NMSBPCSLDHB, L.P v. Integrated Telecom Expr. Inc. (In re Integrated Telecom Expr. Inc.), 308 F.3d 108 (3d Cir. 2004) (plan of reorganization failed to meet "good faith" filing requirement of 11 U.S.C. § 1129(a)(3) (2000) because sole purpose of bankruptcy filing was to benefit debtors' shareholders at the expense of one lessor whose claim in bankruptcy was limited to one year's rent under 11 U.S.C. $\S$ 502(b)(6)(A) (2000)). Cf. also In re Owens Corning, 419 F.3d 195, 216 (3d Cir. 2005) (Deemed substantive consolidation as to certain creditors denied because "it is here a tactic used as a sword and not a shield.").

${ }^{63}$ Neal Mitchell Assocs. v. Braunstein (In re Lambeth Corp.), 227 B.R. 1, 7 (B.A.P 1st Cir. 1998).

${ }^{64} 465$ U.S. 513 (1984).

6529 U.S.C. $\S 150$ et seq. (1982).

${ }^{66} 465$ U.S. at 516. In reaction to Bildisco, Congress enacted section 1113 of the Bankruptcy Code to
} (C) 2006, Adam J. Levitin 
The Court did not debate the existence, extent, or role of bankruptcy equity in Bildisco.

The Court assumed equity to be a defining characteristic of bankruptcy courts' operations and explained the nature of bankruptcy equity in Chapter 11: to balance the interests and potential hardships of all the parties involved as they would affect the success of a reorganization. The balancing is left to the business judgment of the bankruptcy court.

The language of the Court's decision is illuminating and worth quoting at length:

Since the policy of Chapter 11 is to permit successful rehabilitation of debtors, rejection [of an executory contract] should not be permitted without a finding that that policy would be served by such action.... Determining what would constitute a successful rehabilitation involves balancing the interest of the affected partiesthe debtor, creditors, and employees. The Bankruptcy Court must consider the likelihood and consequences of liquidation for the debtor absent rejection, the reduced value of the creditors' claims that would follow from affirmance and the hardship that would impose on them, and the impact of rejection on the employees. In striking the balance, the Bankruptcy Court must consider not only the degree of hardship faced by each party, but also any qualitative differences between the types of hardship each may face.

The Bankruptcy Court is a court of equity, and in making this determination it is in a very real sense balancing the equities, as the Court of Appeals suggested. Nevertheless, the Bankruptcy Court must focus on the ultimate goal of Chapter 11 when considering these equities. The Bankruptcy Code does not authorize freewheeling consideration of every conceivable equity, but rather only how the equities relate to the success of the reorganization. The Bankruptcy Court's inquiry is of necessity speculative, and it must have great latitude to consider any type of evidence relevant to this issue. ${ }^{67}$

Bildisco leaves no doubt that a balancing of equities in light of bankruptcy policy goals, rather than a statutory checklist, is central to bankruptcy adjudication. Of course, one might ask how this is different from any assignation of a matter to a court's discretion, such as in sentencing or determining whether the probative value of evidence outweighs its prejudicial tendency. One

govern the rejection of collective bargaining agreements. 11 U.S.C. $\S 1113$ (2000). While Bildisco's holding on what procedures govern the rejection of collective bargaining agreements is no longer applicable law, the enactment of section 1113 in no way vitiates the general applicability of Bildisco's discussion of the role of equity in Chapter 11 proceedings, which was not confined to the context of section 1113.

${ }^{67}$ Id. at 527. 
might further ask how this differs from the discretion exercised by administrative law judges, whose powers, like those of bankruptcy judges, do not stem from Article III of the Constitution.

The Bildisco court was emphasizing that the Bankruptcy Code cannot presumptively be read on its face like any other statute. The application of the statutory language of the Code, then, cannot be a robotic exercise, and literal meaning is not enough, for the Code's provisions must be evaluated in light of the policies embodied in the Code. The need to evaluate statutes in light of the policies they embody is hardly a novel concept in statutory interpretation. ${ }^{68}$ Nonetheless, Bildisco's purposivist emphasis on the policy goals of bankruptcy over a purely textualist approach is in marked contrast to much of the Court's recent bankruptcy jurisprudence. In Bildisco, though, the Court was emphasizing that the Code must be read as containing terms of art, written in light of equitable interpretation and application. As Justice Douglas wrote in Bank of Marin v. England, "[We] do not read these statutory words with the ease of a computer. There is an overriding consideration that equitable principles govern the exercise of bankruptcy jurisdiction." 69

What the Court indicated in Bildisco is that in Chapter 11 the goal of debtor rehabilitation is to guide the balancing of the equities and that a tie goes to the debtor. In balancing the equities, weighting should not be done by the dollar value of claims. While all prayers for relief, be they for monetary or injunctive remedies, are reduced to monetary claims in bankruptcy by section 502(c)(2), ${ }^{70}$ the Court's emphasis on the qualitative nature of parties' hardships means that bankruptcy courts should look to the original nature of the claim. Thus, economic harms should not necessarily be weighed the same as non-economic harms. Tort victims, employees,

\footnotetext{
${ }^{68}$ E.g., United States v. Heirs of Boisdore, 8 How. 113, 122 (1849) (“In expounding a statute, we must not be guided by a single sentence or member of a sentence, but look to the provisions of the whole law, and to its object and policy.").

${ }^{69} 385$ U.S. 99, 103 (1966).

${ }^{70} 11$ U.S.C. $\S 502(c)(2)(2000)$.
}

(C) 2006, Adam J. Levitin 
trade creditors, and financial creditors need not be treated the same on a per-dollar basis in balancing equities. The non-pecuniary harms that would result from a determination should be weighed in the equation. ${ }^{71}$

Bildisco's emphasis on doing substantial justice through balancing competing equities has often been forgotten by courts that are less comfortable with the judicial discretion involved in weighing equities. These courts have turned instead to the talismans of statutory authorization and the pre-Code practices doctrine to guide their decisions by limiting equitable discretion and the ability to do substantial justice. The next section considers why courts are so uncomfortable with equitable discretion.

\section{JUDICIAL DISCOMFORT WITH EQUITABLE DISCRETION}

\section{A. SEPARATION OF POWERS CONCERNS}

The exercise of discretion is a concern throughout the American judicial system because it is in some sense a lawmaking activity. In our Constitutional system, the legislative power is the power to set rules of decision, which vested in Congress at the federal level. The separation of powers principle holds that the legislature makes the laws and the judiciary merely interprets them. Broad judicial discretion is problematic because it changes the rule of decision from one set by the legislature to one set by the adjudicator.

The actual separation of powers is often blurrier than standard civics classes present it. The legislature can delegate its powers, for example. ${ }^{72}$ The existence and scope of such a delegation is a major concern in the realm of administrative law, where a central question is the scope of the rule-making authority of administrative agencies. If there is a proper delegation lawmaking power to the judiciary, either by the Constitution or by Congress, then judicial

${ }^{71}$ Unfortunately, Bildisco does not indicate anything about how equities should be weighed in Chapter 7 or Chapter 13 cases, or arguably in liquidating Chapter $11 \mathrm{~s}$.

${ }^{72}$ E.g., Texas Indus., Inc., v. Radcliff Materials, Inc. 451 U.S. 630, 640 (1981).

(C) 2006, Adam J. Levitin 
discretion is does not present such serious separation of powers concerns; rather the powers of each branch of government are simply redefined.

Moreover, it is hard to draw a bright line between judicial interpretation and lawmaking; these activities exist along a spectrum. ${ }^{73}$ At one end of the spectrum is the interpretation of statutory terms; at the other is the creation of new rules of decision or causes of action. Somewhere in between stands what might be termed "interstitial lawmaking" —filling in statutory gaps, rather than creating law out of whole cloth.

Interpretation of the law is part of the unquestioned role of the judiciary, ${ }^{74}$ and to the extent that administrative agencies assume this judicial role, of agency action. ${ }^{75}$ Judicial lawmaking in the sense of creating new rules of decision, however, is often viewed with great suspicion as "judicial activism," violating the separation of powers principle. ${ }^{76}$ Interstitial lawmaking by expert bodies, be they agencies or specialized courts, is also generally tolerated because it is necessary in the modern state.

Agency rulemaking can span the entire spectrum from interpretation to creation of new rules of decision. The courts police such rulemaking by examining the statutory authorization for the rule-making power and determining whether the rulemaking was within the scope of the

\footnotetext{
${ }^{73}$ Martha A. Field, Sources of Law: The Scope of Federal Common Law, 99 HARV. L. REV. 883, 893-94 (1986); Peter Westen \& Jeffrey Lehman, Is There Life for Erie After the Death of Diversity?, 78 MicH. L. REV. 311, 332 (1980); but cf. Martin H. Redish, Federal Common Law, Political Legitimacy, and the Interpretive Process: An "Institutional” Perspective, 83 Nw. U. L. REV. 761, 788 (1989) ("[T]he difference between common law and statutory interpretation are [sic], both conceptually and politically, qualitatively different."). Notably, Redish defines many of the points along the spectrum as interpretation in order to achieve a neater binary divide. Id. at 794.

${ }^{74}$ Marbury v. Madison, 5 U.S. 137 (1803).

${ }^{75}$ See, e.g., Chevron U.S.A. Inc. v. Nat'l Resources Def. Council, 467 U.S. 837 (1984).

${ }^{76}$ E.g., Sosa v. Alvarez-Machain, 542 U.S. 692, 750 (2004) (Scalia, J., concurring) ("We Americans have a method for making the laws that are over us. We elect representatives to two Houses of Congress, each of which must enact the new law and present it for the approval of a President, whom we also elect. For over two decades now, unelected federal judges have been usurping this lawmaking power....").
} 
authorization. ${ }^{77}$ Many courts also have adopted this approach when attempting to determine the authorization of bankruptcy courts to depart from the strictures of the Bankruptcy Code. Accordingly, the struggle over non-Code practices has largely become a debate about the scope of the statutory authorization of bankruptcy courts' equitable powers. As the following section shows, the existence of any such statutory authority at present is doubtful, and the debate over non-Code practices has been misframed in terms of equity for historical reasons. Instead, this article argues, non-Code practices should be viewed in terms of federal common law. The use of the term "equity" in the bankruptcy context is really "fortuitous coinage" for what is better described as federal common lawmaking.

The misframing of the authorization of non-Code practices in terms of equity has been particularly problematic because of the peculiar difficulties that equitable discretion and powers present for any statutory regime. The nature of equity is to be flexible and individualized, while the purpose of a code is to provide clear ex-ante rules that will result in uniform decisions. Allowing courts that implement a code-based regime to go farther afield than the statutory language undercuts the point of codification. To the extent that equitable powers authorize unlimited deviations from the Code, they present the danger of the exceptions swallowing the rule.

\section{B. “DOING LAW" VERSUS "DoING JUSTICE"}

The misidentification of the authorization of non-Code practices as stemming from the equity powers of bankruptcy courts has led courts to apply inappropriate statutory and historical limitations on non-Code practices because of discomfort with unguided equitable discretion. Judicial discomfort with equity complicates any attempt to reconcile equity powers with a code-

${ }^{77}$ See, e.g., FDA v. Brown \& Williamson Tobacco Corp., 529 U.S. 120, 125-26 (2000).

(C) 2006, Adam J. Levitin 
based legal regime. The term "equity" itself seems to set off judicial alarm-bells. A general judicial nervousness about "doing justice" instead of "doing law" has been imbedded in our legal system at least since Marbury v. Madison. ${ }^{78}$ This judicial unease has become distinctly more pronounced on the Rehnquist court with its comparatively textualist emphasis.

Marbury, which lies at the bedrock of the American statutory-Constitutional state, looks to positive rights created by statute or the Constitution. Marbury emphasized "where there is a legal right, there is also a legal remedy."79 At the center of equity jurisprudence, however, lies the maxim that "Equity will not suffer a wrong to be without a remedy." 80 Equity thus looks to the existence of a wrong, which assumes something approaching a divine or natural law set of rights, as opposed to a statutory right. ${ }^{81}$ For example, the notoriously vague notion of fiduciary duties are rarely put into a statutory form; they exist, but not by virtue of legislative decree. These sorts of rights might have historical origins, but they are affirmatively non-statutory. ${ }^{82}$ Statute and equity are adjudicative systems based on drastically divergent principles of the derivation of rights.

American legal education judges are trained to protect statutory rights and to do law, not justice. $^{83}$ In part, though, it stems from the lack of a generally accepted meaning of what

${ }^{78} 5$ U.S. 137 (1803).

${ }^{79} \mathrm{Id}$. at 163 .

${ }^{80}$ SNELL, PRINCIPLES OF EQUiTY 24 (27th Ed. 1973) ("Indeed, it would not be difficult to reduce [all of the equity maxims to two:] 'Equity will not suffer a wrong to be without a remedy', and 'Equity acts on the person."'). This maxim also appears as ubi jus ibi remedium (where there is a right, there is a remedy) and lex semper dabit remedium (the law always gives a remedy), formulations that are much closer to that of Marbury v. Madison.

${ }^{81}$ The office of Lord Chancellor was originally held by a prelate. Krieger, supra note 1, at 279.

${ }^{82}$ Cf. Griswold v. Connecticut, 381 U.S. 479, 492 (1965) (Goldberg, J., concurring).

83 Oral Argument, In re: John Amendt, No. 05-2458 (3d Cir., Jan. 18, 2006) at http://ca3phi02/iptvmedia/05-2458InReJohnAmendt.wmv at 13:49. (Becker, J.) (Petitioner urging court to grant mandamus to prevent venue transfer of an ERISA case under an abuse of discretion standard) (Judge Becker: "When you [petitioner's counsel] say how [will we] explain to ourselves [a denial of mandamus, we respond]-We'll follow the law. Your suggestions here that this [transfer of venue] is grotesque and all the rest of this. This is a legal case. This is going to be decided on the law, not on the 
substantial justice is. While society might have a common sense of what is just in some situations, there are many technical scenarios for which no societal consensus exists. "Doing justice" is too much of a generality to provide meaningful guidance to courts. In America judges do law, not justice, so the idea of the law instructing them to do substantial justice—"a roving commission to do equity" ${ }^{84}$-is quite unnerving.

The jurisprudential concern about "doing equity" is not just one of a lack of uniform results between courts, but one of judges themselves not knowing how to proceed. It is far easier to follow the techniques of application of law to fact taught in law school than to create justice out of whole cloth; judges are not Solomons. Nor are they generally technical experts in any particular field. Without some channeling or direction of their discretion, many judges would simply be lost, particularly in cases where one's personal moral (or economic efficiency) compass can give no bearing. This concern was evident in the Supreme Court's decision in Butner v. United States, in which the Court ruled that state law, rather than a "federal rule of equity" ${ }^{\prime 5}$ should govern the right to rents collected during the period between a mortgagor's bankruptcy and the foreclosure sale of the mortgaged property: ${ }^{86}$

The equity powers of the bankruptcy court play an important part in the administration of bankrupt estates in countless situations in which the judge is required to deal with particular, individualized problems. But undefined considerations of equity provide no basis for adoption of a uniform federal rule affording mortgagees an automatic interest in the rents as soon as the mortgagor is declared bankrupt. ${ }^{87}$

The problem for the Supreme Court was that considerations of equity were "undefined," and the

emotions....To think that the Third Circuit Court of Appeals is gonna to decide on the basis of emotional arguments! There are emotional factors on both sides are every case. There are legal issues here. And when you say 'how do you explain to people?' You have to explain that a federal appellate court is confronted with certain precedents, like our precedent on mandamus, and these other things....").

${ }^{84}$ United States v. Sutton, 786 F. 2d 1305, 1308 (5th Cir. 1986).

${ }^{85}$ Butner, 440 U.S. at 49, 53.

${ }^{86} I d$. at 49.

${ }^{87} I d$. at 55-56. 
Court did not feel comfortable providing such a definition itself. The circuits that had adopted a "federal rule of equity" to govern the situation had reasoned that "since the bankruptcy court has the power to deprive the mortgagee of his state-law remedy, equity requires that the right to rents not be dependent on state-court action that may be precluded by federal law." 88 This rule, however, sometimes "affords the mortgagee rights that are not his as a matter of state law." 89 The Supreme Court reasoned that state law should govern because treating a party's property rights different in bankruptcy than under state law could allow bankruptcy to become a windfall to certain parties, ${ }^{90}$ an "inequity" that using state law as the rule of decision would avoid. ${ }^{91}$ The Supreme Court was concerned that entering into a consideration of equity would itself create inequity because these considerations were "undefined."

The Supreme Court's concern about "undefined considerations of equity" was in part because of the issue at hand. The question of automatic security interests in rents is a technical, financial question; it does not implicate social values and mores the way issues like non-statutory substantive due process rights such as abortion or First Amendment issues, or statutory rights such as sentencing schemes do. Without the strong tug of a moral compass, it is far easier for federal courts to disregard equitable considerations and defer to the terms of a statutory scheme, state law, and established precedent.

The Bankruptcy Code does not make courts' task any easier. The Code provides no guidance for what it means to be a "court of equity," and the origins of this status are murky.

\footnotetext{
${ }^{88} I d$. at 53.

${ }^{89} \mathrm{Id}$. at 56.

${ }^{90} \mathrm{Id}$. at 55.

${ }^{91} I d$. at 56-57.
} 


\section{THE LIMITATION OF BANKRUPTCY EQUITY BY STATUTORY LANGUAGE}

\section{A. SPECIFIC AUTHORIZATIONS OF EQUITY IN THE BANKRUPTCY CODE}

The current Bankruptcy Code authorizes equitable decision-making in a limited number of circumstances. The Code refers twenty-four times to decisions that are to be made "according to the equities of the case" or "in the interests of justice." 92 Several of these provisions are

\footnotetext{
${ }^{92}$ See 11 U.S.C. $\$ 365(d)(10)$ (2000) (trustee is to perform all obligations of the debtor on an unexpired lease of personal property unless court decides otherwise "based on the equities of the case."); 11 U.S.C. $\S 502(\mathrm{j})$ (2000) (reconsideration of allowed or disallowed claim is to be made "according to the equities of the case"); 11 U.S.C. § 510(c)(1) (2000) (claims may be subordinated "under principles of equitable subordination"); 11 U.S.C. $§ 524(\mathrm{~g})(2)(\mathrm{B})(\mathrm{ii})(\mathrm{III})$ (asbestos channeling injunction may only be issued if pursuit of claims outside of plan would likely threaten "plan's purpose to deal equitably with claims and future demands"); 11 U.S.C. $§ 524(\mathrm{~g})(4)(B)(i i)$ (2000) (injunction issued in conjunction with chapter 11 plan only if "the court determines...such injunction...is fair and equitable"); 11 U.S.C. § 524(h)(1)(A) (2000) (referencing the "fair and equitable" requirements of 11 U.S.C. § 1129(b)); 11 U.S.C. § 552(b)(1) (2000) (after acquired property clauses in security agreements are valid except to the extent that the court orders otherwise after notice and a hearing "based on the equities of the case."); 11 U.S.C. § 552(b)(2) (2000) (limitation on post-petition effect of after-acquired property clauses of security agreements to be "based on the equities of the case"); 11 U.S.C. $§ 557(d)(2)(D)$ (2000) (disposition of grain or proceeds of grain may be by "such other method as is equitable in the case"); 11 U.S.C. § 723(d) (2000) (determination of distribution of surplus recovered by a partnership trustee against general partners shall be equitable); 11 U.S.C. $§ 1112$ (d)(3) (2000) (conversion of case from chapter 11 to chapter 12 must be equitable); 11 U.S.C. $§ 1113(b)(1)(A)$ (2000) (debtor rejecting a collective bargaining agreement shall make a proposal for modifications in employee benefits and protections that assures that "all creditors, the debtor, and all of the affected parties are treated fairly and equitably"); 11 U.S.C. § 1113(c)(3) (2000) (collective bargaining agreements to be rejected only if "the court finds...the balance of the equities favors rejection"); 11 U.S.C. $§ 1114(f)(1)(A)$ (2000) (debtor modifying retiree benefits must assure that "all creditors, the debtor, and all of the affected parties are treated fairly and equitably"); 11 U.S.C. $\S$ 1114(g)(3) (2000) (modification of payment of retiree benefits if "all creditors, the debtor, and all of the affected parties are treated fairly and equitably, and [a modification of the order] is clearly favored by the balance of the equities"); 11 U.S.C. $§ 1129(b)(1)$ (2000) (cramdown plan must be "fair and equitable" to be confirmed); 11 U.S.C. § 1129(b)(2) (2000) (defining what "fair and equitable" includes for the purposes of $\S 1129(\mathrm{~b})(1)$ ); 11 U.S.C. $\S 1170(\mathrm{e})(1)$ (2000) (approval of abandonment of railroad line requires "a fair arrangement at least as protective of the interests of employees as that established under section 11347 of title 49"); 11 U.S.C. § 1172(c)(1) (2000) (approval of railroad reorganization plan requires "a fair arrangement at least as protective of the interests of employees as that established under section 11347 of title 49"). See also 11 U.S.C. § 1228(b)(1) (2000) and 11 U.S.C. § 1328(b)(1) (2000) ("circumstances for which the debtor should not justly be held accountable" for failure to make payments under a plan); 11 U.S.C. § 524(c)(3)(B) (2000) and 11 U.S.C. § 524(c)(6)(A)(i) (2000) (no "undue hardship"); 11 U.S.C. § 557(f)(1) (2000) ("in the interests of justice"). Many historically equitable doctrines, such as good faith, see 11 U.S.C. $§ 1129$ (a)(3) (2000), fraud, see 11 U.S.C. $§ 548$ (2000), and laches, see 11 U.S.C. $§ 524$ (2000), are incorporated throughout the Code, but without allowing judicial discretion.
} 
essentially parallel to each other or interlinked as parts of a single Code section. ${ }^{93}$ Accounting for parallel or interlinked provisions, there are only fourteen truly distinct provisions that call for doing equity, and in only one of these provisions, 11 U.S.C. $§ 1129(b)$, does the Code spell out what equity requires. ${ }^{94}$ Section $1129(\mathrm{~b})(1)$ requires that a "cramdown" reorganization plan that is adopted over the objections to a class of creditors must be "fair and equitable." 95 Section 1129(b)(2) then lists a set of non-exclusive conditions defining what it means to be "fair and equitable." 96 The conditions listed are not broadly applicable principles of adjudication, but specific requirements for cramdown plans, so section 1129(b)(2) does little to inform the exercise of equity in other areas where the Code calls for it.

\section{The Bark and the Bite of Norwest Bank Worthington v. Ahlers: How Confining Is the Code?}

Section 1129(b) was the statutory provision at issue in Norwest Bank Worthington v. Ahlers, the Supreme Court's most rhetorically striking decision on the scope of courts' equitable powers in bankruptcy. ${ }^{97}$ The issue before the Court in Ahlers was whether the absolute priority rule has a "new value" exception for contributions by equity holders of "labor, experience, and expertise" to a debtor's operations. The absolute priority rule, codified at 11 U.S.C. $\S$ 1129(b)(2)(B), requires that equity holders in a debtor enterprise receive nothing in a

${ }^{93}$ Cf. 11 U.S.C. $\S 524(\mathrm{~g})(2)(\mathrm{B})(\mathrm{ii})(\mathrm{III})$ and 11 U.S.C. $\S 524(\mathrm{~g})(4)(\mathrm{B})(\mathrm{ii})(2000) ; 11$ U.S.C. § 552(b)(1) (2000) and 11 U.S.C. § 552(b)(2) (2000); 11 U.S.C. § 1113(b)(1)(A) (2000), 11 U.S.C. § 1113(c)(3) (2000), 11 U.S.C. § 1114(f)(1)(A) (2000), and 11 U.S.C. § 1114(g)(3) (2000); 11 U.S.C. § 1129(b)(1) (2000) and 11 U.S.C. § 1129(b)(2) (2000) and 11 U.S.C. § 524(h)(1)(A) (2000); 11 U.S.C. § 1170(e)(1) (2000) and 11 U.S.C. $\S 1172(c)(1)(2000) ; 11$ U.S.C. $\S \S 1228(b)(1)(2000)$ and 1328(b)(1) (2000); 11 U.S.C. $\S \S 524(\mathrm{c})(3)(B)(2000)$ and 524(c)(6)(A)(i) (2000).

${ }^{94}$ Arguably, 11 U.S.C. $\$ 1170(\mathrm{e})(1)$ and 11 U.S.C. $\$ 1172(\mathrm{c})(1)$ originally detailed a measure for equity, in that they call for railroad reorganization plans, including the abandonment of a railroad line to contain "a fair arrangement at least as protective of the interests of employees as that established under section 11347 of title 49." 49 U.S.C. 11347 has since been omitted. See Pub. L. 104-88, title 1, § 102(a), Dec. 12, 1995, Stat. 804. See 49 U.S.C. § 11326(a) (2000).

${ }^{95} 11$ U.S.C. $\$ 1129(\mathrm{~b})(1)(2000)$.

${ }^{96} 11$ U.S.C. $\$ 1129(b)(2)(2000)$.

${ }^{97} 485$ U.S. 197 (1988). 
reorganization unless all the classes of creditors above them receive property of value equal to the allowed amount of their claims. The Supreme Court declined to rule on the proposed “infusion-of-money-or-money's-worth" exception to the absolute priority rule. Instead, it held that even if there were such an exception after the codification of the absolute priority rule in section 1129(b), the instant contribution was insufficient. ${ }^{98}$

The debtors in Ahlers argued that section 1129(b)'s provision that a reorganization be "fair and equitable" required the objecting creditor to vote "in the best interests of all creditors and debtors", not merely its own self-interest. ${ }^{99}$ The debtors also emphasized their sympathetic status as hard-pressed family farmers. ${ }^{100}$ The Court sharply rejected their equity argument, declaring, "whatever equitable powers remain in the bankruptcy courts must and can only be exercised within the confines of the Bankruptcy Code."101 In this case, the confine that limited equity was section 1129(b)(2)(B), which laid out what constituted a "fair and equitable" plan.

What exactly does it mean that bankruptcy equity "can only be exercised within the confines" of the Code? This phrase has become the standard retort to "the bankruptcy court is a court of equity." First, it could mean that equity is only a power to implement the Code. If so, though, it is odd to call it equity, as this power exists for all federal courts under the All Writs Act. $^{102}$ In any case, this reading is probably precluded by the Court's later decision in United States v. Energy Resources Co., Inc., where it observed that section 105(a) powers "are consistent with the traditional understanding that bankruptcy courts, as courts of equity, have broad authority to modify creditor-debtor relationships."103 Modifying creditor-debtor

\footnotetext{
${ }^{98} I d$. at 203 n.3.

${ }^{99} I d$. at 206.

${ }^{100}$ Id. at 209.

${ }^{101} \mathrm{Id}$. at 206.

10228 U.S.C. $\$ 1651(2000)$.

${ }^{103} 495$ U.S. 545, 549 (1990).
} 
relationships goes far beyond enforcement of court orders.

Ahlers could also mean that bankruptcy equity is synonymous with the terms of the Code, that is to say that the terms of the Code are equity codified. ${ }^{104}$ This reading can be squared with Energy Resources, as "broad authority to modify creditor-debtor relationships" can be read as a description of bankruptcy court's statutory powers. Nonetheless, this reading too fails, for the Code would not require actions to be "fair and equitable" if that is exactly what the Code's provisions were. The Code's fourteen provisions referring to equity would be superfluous if the Code itself were equity.

A third reading of Ahlers, adopted by many courts, is that equity powers must be consistent with the Code's specific provisions. ${ }^{105}$ Such a reading mirrors section 1123(b)(5) of the Code, which authorizes bankruptcy courts to approve reorganization plans containing "any... appropriate provision not inconsistent with the applicable provisions of this title."106 This reading too is consistent with Energy Resources, as well as with the Supreme Court's admonition that "courts should be loath to announce equitable exceptions to legislative requirements or prohibitions that are unqualified by the statutory text." ${ }^{\text {107 }}$ It is also consistent with the Court's jurisprudence under the Bankruptcy Act of $1898 .^{108}$

This third reading also comports with the Supreme Court's later decision in Young v.

\footnotetext{
${ }^{104}$ Krieger, supra note 1, at 311. ("equity lies not in the court, but in the Bankruptcy Code it applies.").

${ }^{105}$ E.g., Jamo v. Katahdin Fed. Credit Union (In re Jamo), 283 F.3d 392, 403 (1st Cir. 2002) (bankruptcy court lacked power to modify a reaffirmation agreement or compel the parties to enter into a judiciallycrafted reaffirmation agreement) ("Section 105(a) does not provide bankruptcy courts with a roving writ, much less a free hand. The authority bestowed thereunder may be invoked only if, and to the extent that, the equitable remedy dispensed by the court is necessary to preserve an identifiable right conferred elsewhere in the Bankruptcy Code.").

10611 U.S.C. $\$ 1123(b)(5)(2000)$.

${ }^{107}$ Guidry v. Sheet Metal Workers Nat'l Pension Fund, 493 U.S. 365, 376 (1990).

${ }^{108}$ See, e.g., SEC v. United States Realty, 310 U.S. 434, 455 (1940).
}

(C) 2006, Adam J. Levitin 
United States. ${ }^{109}$ In Young the Court unanimously held that the three-year lookback period of section $507(\mathrm{a})(8)(\mathrm{A})(\mathrm{i}){ }^{110}$ which mirrors the three-year statute of limitations of the Internal Revenue Code ${ }^{111}$ and grants the Internal Revenue Service a priority position for its tax liens, is tolled during the pendency of a prior bankruptcy under the principle of equitable tolling. The Court noted, "Since nothing in the Bankruptcy Code precludes equitable tolling of the lookback period, we believe the courts below properly excluded from the three-year limitation the period [at issue]."112 In Young, Court had no difficultly allowing an equitable practice not specifically authorized by the Code because it was not precluded by the Code.

Under the third reading, so long as there is not a specific Code provision directly on point, the court has a free hand in deciding whether and how to use its equity powers, limited only by the extent of those powers and proper exercise of its discretion. ${ }^{113}$ Such a reading is consistent with the nature of equity discussed in Pepper $v$. Litton-that equity ensures that substantial justice will not be bound by technical considerations. Thus, when it is a close call whether the exercise of equity powers would be inconsistent with or contradict the Code, the third reading's presumption should be in favor of allowing the exercise of the equity powers. ${ }^{114}$

The problem with readings Ahlers in any of these ways is that it ignores the case's unusual statutory context. When one reads Ahlers statement that "whatever equitable powers remain in the bankruptcy courts must and can only be exercised within the confines of the

\footnotetext{
${ }^{109} 535$ U.S. 43 (2002).

11011 U.S.C. $\$ 507$ (a)(8)(A)(i) (2000).

11126 U.S.C. $\$ \S 6501-6502(2000)$.

${ }^{112}$ Young v. United States, 535 U.S. 43, 47 (2002).

${ }^{113}$ See Energy Res. Co., 495 U.S. at 549-50 ("Even if consistent with the Code, however, a bankruptcy court order might be inappropriate if it conflicted with another law that should have been taken into consideration in the exercise of the court's discretion.").

${ }^{114}$ There is also a fourth reading of Ahlers, which is really a broader version of the third reading. This fourth reading is that equity must be consistent not just with the Code's specific provisions, but with the general tenor of the Code and the policies underlying it.
}

(C) 2006, Adam J. Levitin 
Bankruptcy Code,"115 not as a free-floating statement of a generic truth, but as it was made, within the context of the case, its narrow scope becomes apparent: Ahlers' statement that equity exists solely within the confines of the Code can apply only to objections to section a plan not meeting the requirements of section 1129(b).

This is not because section 1129(b) was the actual issue litigated in the case; it would be reckless to read the Supreme Court's decision so narrowly. Rather, it is because section 1129(b) is the only section of the Code that refers to "fair and equitable" and then defines some of the requirements of fairness and equity for the purposes of the section. There is no other section of the Bankruptcy Code that explicitly defines what "equity" requires in a specific condition. The rest of the Code lacks any such "confines" of directly applicable statutory language. Therefore, the "confines of the Bankruptcy Code" are much less confining for other equity-based claims. Instead of the tight fence of the statutory specifications in section 1129(b)(2), there is only the porous boundary of general inferences of indirectly conflicting statutory provisions. Ahlers' bark is far worse than its bite.

Nonetheless, the fourteen discrete situations in which the Code calls for the exercise of equitable principles in decision-making are hardly enough for a bankruptcy court to be called "a "court of equity." Some of the specific Code provisions requiring decisions to be made "in the interests of justice" deal with such obscure topics as "the period for the final disposition of grain or proceeds of grain."116 The status of "court of equity" implies a larger scope to bankruptcy courts' equity powers than the fourteen specific directives of the Code. As the Supreme Court noted in Energy Resources, its most recent decision touching on the equity powers of bankruptcy courts, "bankruptcy courts, as courts of equity, have broad authority to modify creditor-debtor

\footnotetext{
${ }^{115} I d$.

${ }^{116} 11$ U.S.C. $\S 557(f)(2000)$.
} 
relationships."117 The scope of such "broad authority" must be understood to apply to more areas of bankruptcy proceedings than determinations on the proceeds of grain. The following section considers what statutory authorization, if any, there is for bankruptcy courts' general, rather than specific, equity powers.

\section{B. IS THERE A GENERAL STATUTORY AUTHORIZATION FOR BANKRUPTCY EQUITY POWERS?}

In Anglo-American legal tradition, bankruptcy relief has only existed as a matter of statute; it has never been a Constitutional or common law right or existed as part of general Chancery powers in equity. ${ }^{118}$ If bankruptcy proceedings themselves are a creature of statute, it would follow a fortiori that the powers of bankruptcy courts are also statutorily limited. This principle was recognized by the Supreme Court in an early bankruptcy case, decided under the second bankruptcy act, Ex parte, the City Bank of New Orleans (In the Matter of William Christy), ${ }^{119}$ which held that the equity powers of district courts sitting in bankruptcy derive only from the Bankruptcy Act of 1841. ${ }^{120}$

Historically, bankruptcy courts had equity powers as a matter of statute. Today, this article demonstrates, there is no longer direct statutory authorization, and the Code provision that courts generally cite as the source of bankruptcy equity powers, 11 U.S.C. $\S 105(\mathrm{a})$, is affirmatively not a statutory authorization of equity. Currently there is no statutory authorization for bankruptcy equity powers; to the extent that they now exist it is only as a matter of federal common law. Thus, to understand the problems of statutory authorization of equity power under

\footnotetext{
${ }^{117} 495$ U.S. 545, 549 (1990).

${ }^{118}$ Krieger, supra note 1, at 275, 277-292. See also Plank, supra note 11, at 668; Berry v. Root, 148 F. $2 d$ 945, 946 (5th Cir. 1945) ("While a court of bankruptcy often applies equitable principles, and may sometimes entertain a controversy in equity arising out of the bankruptcy in which it will follow the precedents and practice of a court of equity, yet as respects the original bankruptcy proceeding it is not strictly a court of equity, but a statutory court created by the Bankruptcy Act, and governed by it.").

11944 U.S. 292. 311-313 (1845).

${ }^{120} 27$ Cong. Ch. 9; 5 Stat. 440 (1841).
}

(C) 2006, Adam J. Levitin 
the current Bankruptcy Code of $1978,{ }^{121}$ it is necessary to foray into the preceding Bankruptcy Act of $1898,{ }^{122}$ which built on the history, and, at times the language of the 1841 Act, albeit through the intervening 1867 Act. ${ }^{123}$ In 2005, the Supreme Court noted, "[o]n occasion, a would-be doctrinal rule or test finds its way into our case law through simple repetition of a phrase --- however fortuitously coined." 124 Although the precise origin of the "court of equity" maxim remains uncertain, the history of American bankruptcy law shows that bankruptcy courts' status as a "court[s] of equity" is less an official statutory status of particular significance than "fortuitous coinage" that has taken on a life of its own and outlived its statutory origins.

\section{Section 2(a)(1) of Bankruptcy Act of 1898}

In Pepper v. Litton, the status of bankruptcy courts as "courts of equity" hinged on a specific statutory authorization, section 2 of the Bankruptcy Act of $1898:{ }^{125}$

Courts of bankruptcy are constituted by $\S \S 1$ and 2 of the Bankruptcy Act [of 1898] and by the latter section are invested "with such jurisdiction at law and in equity as will enable them to exercise original jurisdiction in bankruptcy proceedings." Consequently this Court has held that for many purposes "courts of bankruptcy are essentially courts of equity, and their proceedings inherently proceedings in equity.” By virtue of $\S 2[$,$] a bankruptcy court is a court of equity$ at least in the sense that in the exercise of the jurisdiction conferred upon it by the Act, it applies the principles and rules of equity jurisprudence. ${ }^{126}$

Section 2(a)(1) of the 1898 Act laid out the jurisdiction of bankruptcy courts:

That the courts of bankruptcy....are hereby invested, within their respective territorial limits... with such jurisdiction at law and in equity as will enable them

\footnotetext{
121 U.S.C. $\S 101$ et seq. (2000).

${ }^{122}$ Bankruptcy Act of 1898, 55 Cong. 2nd Sess., Ch. 541, 30 Stat. 544 (1898) (codified as amended at 11 U.S.C. §§ 1-1103 (1976 \& Supp. II 1978) (repealed 1978)).

${ }^{123}$ See Steve H. Nickles \& David G. Epstein: Bankruptcy Symposium: Another Way of Thinking About Section 105(a) and Other Sources of Supplemental Law Under the Bankruptcy Code, 3 CHAP. L. REV. 7 , 13-14 (2000).

${ }^{124}$ Lingle v. Chevron U.S.A. Inc., 125 S.Ct. 2074 (2005) (holding that the "substantially advances government interests" test for regulatory takings does not apply).

${ }_{125}$ Bankruptcy Act of 1898, 55 Cong. 2nd Sess., Ch. 541, 30 Stat. 544, 544-545 (1898) (codified as amended at 11 U.S.C. § 2 (1976 \& Supp. II 1978) (repealed 1978)).

${ }^{126}$ See 308 U.S. at 304 (internal citations omitted).
} 
to exercise original jurisdiction in bankruptcy proceedings.... ${ }^{127}$

Section 2 of the 1898 Act then enumerated a non-exclusive ${ }^{128}$ list of eighteen specific powers of the court. ${ }^{129}$ The fourteenth enumerated power, section 2(a)(15), was to "make such orders, issue such process, and enter such judgments in addition to those specifically provided for as may be necessary for the enforcement of the provisions of this Act."130 Although Pepper v. Litton did not specify which subsection of section 2 of the 1898 Act it referenced, it seems clear that it was referring to section 2(a)(1), given that Local Loan Co. v. Hunt ${ }^{131}$ the authority cited in Pepper, ${ }^{132}$ revolved around that section. ${ }^{133}$

Local Loan Co.'s discussion of section 2(a)(1) clarified that although the jurisdictional grant in the 1898 Act was of both jurisdiction at law and in equity. Jurisdiction at law was granted for the purpose of punishing bankruptcy crimes; otherwise, bankruptcy was an equitable proceeding:

The words "at law" were probably inserted to meet clause (4) of $\$ 2[(a)$ of the Bankruptcy Act of 1898], which empowers such [bankruptcy] courts to arraign, try and punish certain designated persons for violations of the act. But otherwise courts of bankruptcy are essentially courts of equity and their proceedings inherently proceedings in equity. ${ }^{134}$

Thus, statutory authorization for bankruptcy equity in Pepper v. Litton was section 2(a)(1) of the Bankruptcy Act of 1898.

${ }^{127}$ Bankruptcy Act of 1898, 55 Cong. 2nd Sess., Ch. 541, 30 Stat. 544, $544-545$ (1898) (codified as amended at 11 U.S.C. § 2(a)(1) (1976 \& Supp. II 1978) (repealed 1978)).

${ }^{128}$ See id. $\$ 2$ 【I 2.

${ }^{129} I d . \S \S 2(\mathrm{a})(2)-(19)$.

${ }^{130}$ Id. $\S 2(\mathrm{a})(15)$.

131292 U.S. 234 (1934).

132308 U.S. at 304.

${ }^{133} I d$. at 240.

${ }^{134}$ Id. See also Bardes, 178 U.S. at 535 ("the words 'at law,' in the opening sentence conferring on the courts of bankruptcy 'such jurisdiction, at law and in equity, as will enable them to exercise original jurisdiction in bankruptcy proceedings,' may have been inserted to meet clause 4, authorizing the trial and punishment of offences, the jurisdiction over which must necessarily be at law and not in equity.").

(C) 2006, Adam J. Levitin 
The assumption underlying Pepper v. Litton was that bankruptcy courts have equitable powers by virtue of statute, not by virtue of some ex nihilo status as bankruptcy courts. The statutory derivation of equity powers means that these powers must be limited to the extent of the statutory authorization. The statutory authorization of equity powers, and by implication equitable adjudication, is odd for a detailed statutory regime; to the extent that one sees the 1898 Act (or the 1978 Act) as authorizing equity powers, it raises the question why Congress would do so. Arguably, the answer lies in the fact-intensive nature of bankruptcy ${ }^{135}$ and Congress's inability to legislative sufficiently precise rules to govern all situations. Congress wanted a flexible statutory regime. It also speaks to the collective nature of bankruptcy-to divide a limited fund among multiple claimants requires creativity and the balancing of equities.

There is no legislative history to support such a view, however. Congress never articulated such a desire independent of the Code's own provisions. As we shall see, bankruptcy equity in the sense of authorizing broad non-Code powers and equitable decision-making is as much a judicial creation as a legislative one. In any event, repeated revisions of the bankruptcy laws have provided bankruptcy courts with the powers of a court of equity without Congressional comment, perhaps ratifying the exercise of equity powers. ${ }^{136}$ The 1898 Act provided Justice Douglas with a reasonably explicit statutory authorization of equity powers. The current statutory authorization for bankruptcy equity powers under the Bankruptcy Code of 1978 , if any, is less clear.

\section{12 Days of Equity? The Questionable Repeal of 28 U.S.C. $\$ 1481$}

\footnotetext{
${ }^{135}$ See Butner, 440 U.S. at 55-56 ("The equity powers of the bankruptcy court play an important part in the administration of bankrupt estates in countless situations in which the judge is required to deal with particular, individualized problems.").

${ }^{136}$ Cf. FDA v. Brown \& Williamson Tobacco Corp., 529 U.S. 120, 157-58 (2000) (Congressional ratification of prior agency practice may be inferred from absence of comment in later legislation).
} 
As the Bankruptcy Code of 1978 was originally adopted, it contained a provision analogous to section 2 of the Bankruptcy Act of $1898 .{ }^{137} 28$ U.S.C. $\S 1481$, entitled "Powers of bankruptcy court," provided:

A bankruptcy court shall have the powers of a court of equity, law, and admiralty, but may not enjoin another court or punish criminal contempt not committed in the presence of the judge of the court or warranting a punishment of imprisonment. ${ }^{138}$

28 U.S.C. $\S 1481$ would seem to continue the pre-Code equity powers for bankruptcy courts, for, as the Third Circuit has noted, "The enactment of the Code in 1978 increased the degree of regulation Congress imposed upon bankruptcy proceedings, but it did not alter bankruptcy courts' fundamental nature."139

28 U.S.C. $\S 1481$ was supposed to go into effect on April 1, 1984. ${ }^{140}$ Before this occurred, however, the Supreme Court ruled in Northern Pipeline Construction. Co. v. Marathon Pipe Line Co. that the 1978 Code's system of Article I bankruptcy judges was unconstitutional. $^{141}$ Northern Pipeline was decided, in part, on an assumption that 28 U.S.C. $\S$ 1481 was in effect. ${ }^{142}$ Accordingly, the implementation of 28 U.S.C. $\S 1481$ was postponed

\footnotetext{
${ }^{137}$ See Bankruptcy Reform Act of 1978, P.L. 95-598, 92 Stat. 2549 (Nov. 6, 1978), § 241.

13828 U.S.C. $\S 1481$ (1982) (possibly repealed in 1984). The House Report on the Bankruptcy Code noted that section 1481 "gives the bankruptcy court the powers of a court of equity, law, and admiralty. It is the concomitant of the bankruptcy courts increased jurisdiction, and is necessary to enable the bankruptcy court to exercise that jurisdiction and its powers under the bankruptcy code. It is in addition to any power granted under 28 U.S.C. 1651 (the All Writs Statute) or under section 105 of the bankruptcy code." H.R. REP. No. 595; 95th Cong., 1st Sess; HR 8200 (Sept. 8, 1977).

${ }^{139}$ The Official Comm. of Unsecured Creditors of Cybergenics Corp., on behalf of Cybergenics Corp., $v$. Chinery, 330 F.3d 548, 567 (3d Cir. 2003).

${ }^{140}$ Bankruptcy Reform Act of 1978, P.L. 95-598, 92 Stat. 2682 (Nov. 6, 1978), § 402(b). Also see id. 92 Stat. 2683, § 404 (providing for transition from Bankruptcy Act of 1898 to Bankruptcy Code of 1978). For effective date of rest of Bankruptcy Reform Act of 1978, October 1, 1979, see id., 92 Stat. 2682 (Nov. 6, 1978), § 401. Thus, 11 U.S.C. $\S 2$ a continued to be in effect until March 31, 1984. Id. 92 Stat. 2683, § 404(a).

141458 U.S. 50 (1982).

${ }^{142} I d$. at 55. See supra note 140.
} 
several times, ${ }^{143}$ finally going into effect on June $28,1984{ }^{144}$

On July 10, 1984, twelve days after 28 U.S.C. $§ 1481$ became effective, the Bankruptcy Amendments and Federal Judgeship Act of $1984^{145}$ went into effect. Section 113 of the 1984 Amendments noted that 28 U.S.C. $§ 1481$ "shall not be effective,"146 but section 121(a) of the Amendments provided that 28 U.S.C. $§ 1481$ would be effective as of the date of the enactment of the 1984 Amendments, July 12, 1984, ${ }^{147}$ an odd provision for an already effective statute. As a court has noted, this bizarre sequence of enactments is "one of Congress' clumsiest performances."148

Most courts and commentators that have addressed the issue have regarded 28 U.S.C. $\S$ 1481 as repealed. ${ }^{149}$ The last official printing of the United States Code in 2000 does not include 28 U.S.C. $§ 1481$, and Lexis and Westlaw services do not list 28 U.S.C. $§ 1481$ as part of the current United States Code. These courts reason that section 121(a) of the 1984 Amendments was "intended again to postpone the effective date of $\S 1481$ so as to take care of the hiatus

${ }^{143}$ See Pub. L. No. 98-249, 98 Stat. 116 (March 31, 1984) (postponing effective date until May 1, 1984); Pub. L. No. 98-271, 98 Stat. 163 (April 30, 1984) (postponing effective date until May 26, 1984); Pub. L. No. 98-299, 98 Stat. 214 (May 25, 1984) (postponing effective date until June 21, 1984); Pub. L. No. 98325, 98 Stat. 268 (June 20, 1984) (postponing effective date until June 28, 1984).

${ }^{144}$ See Pub. L. No. 98-325, 98 Stat. 268 (June 20, 1984).

14598 P.L. 353; 98 Stat. 333 (1984).

14698 P.L. 353; 98 Stat. 333, § 113 (1984).

14798 P.L. 353; 98 Stat. 333, § 121 (1984).

${ }^{148}$ In re Haddad, 68 B.R. 944, 948 (Bankr. D. Mass., 1987).

149 See, e.g., Industrial Tool Distrib., Inc., 55 B.R. 746, 749 n.6 (Bankr. N.D. Ga. 1985) ("it is highly likely that Congress meant to make $\S 1481$ prospectively ineffective, which is what $\S 113$ of the 1984 Act does. Further, since $\S 1481$ was already in effect and there was no reason no give it an effective date of July 10, 1984, § 121(a) was obviously an oversight."); SEC v. Danning (In re Carter), 759 F.2d 763, 766 (9th Cir. 1985); see City Nat'l Bank of Miami v. Gen. Coffee Corp. (In re Gen. Coffee Corp.), 758 F.2d 1406 (11th Cir. 1985); In re Amatex Corp., 755 F.2d 1034, 1037 n.2 (3d Cir. 1985); Thistlethwaite v. First Nat'l Bank of Lafayette (In re Exclusive Indus. Corp.), 751 F.2d 806, 807 n.1 (5th Cir. 1985); Omega Equip. Corp. v. John C. Louis Co., Inc., 51 Bankr. 569, 572 (D.D.C. 1985); Robinson v. JohnsManville Corp., 52 Bankr. 940, 941 n.2 (S.D.N.Y. 1985). See also 1A COLLIER ON BANKRUPTCY, II 3.01[8a] (15th ed. 1985) ("Section 1481 was effectively repealed by the Bankruptcy Amendments and Federal Judgeship Act of 1984.”); 1987 Advisory Committee Note to Bankruptcy Rule 9020, reprinted in10-9020 COLLIER ON BANKRUPTCY (15th Ed. Rev. 2005) App. 9020, (referring to the "former section 1481); id. n.1 ("With the enactment of Pub. L. No. 98-353 (1984), section 1481 was repealed.").

(C) 2006, Adam J. Levitin 
which then existed between June 28th and July 10th." ${ }^{\prime 150}$ The provisions cannot be read as canceling each other out, as there is no other purpose for section 121(a) than to postpone the effective date until 28 U.S.C. $\S 1481$ became ineffective by virtue of section 113.

On the other hand, there is no legislative history that specifically addressed the repeal of 28 U.S.C. $§ 1481$. The meaning of the conflicting statutory provisions is ambiguous to say the least, and since divining Congressional intent in these circumstances is well nigh impossible, basic principles of statutory interpretation should govern. The plain reading of sections 113 and 121(a) causes the two sections to cancel each other out, leaving 28 U.S.C. $\S 1481$ untouched and effective as of June 28, 1984. ${ }^{151}$ Indeed, as recently as 1996, a bankruptcy court referred to 28 U.S.C. $\S 1481$ in one of its decisions as if it were still in effect. ${ }^{152}$ One can only surmise that if Congress intended to repeal it, that it was because Congress believed that 28 U.S.C. $\S 1481$ 's jurisdictional grant was inconsistent with the holding in Northern Pipeline. Yet, if this were the case, why did Congress continue postponing the implementation date of 28 U.S.C. $\S 1481$, rather than repealing it?

The issue of 28 U.S.C. $\S 1481$ 's repeal is far from clear, and its resolution is far from an academic problem. If bankruptcy courts' equitable powers derive from a textual authorization and that authorization no longer exists, do the powers continue to exist or are the courts acting ultra vires? If the powers do exist even without any statutory authorization, that might affect the application of certain Supreme Court decision to bankruptcy courts. Moreover, if the powers

\footnotetext{
${ }^{150}$ In re Haddad, 68 B.R. 944, 948 (Bankr. D.Mass., 1987).

${ }^{151}$ See Better Homes of Va. v. Budget Serv. Co., 52 B.R. 426, 430 (E.D. Va. 1985) ("under the general rule of statutory construction as to mutually exclusive statutes passed on, and effective on, the same date, $\S 1481$ would remain unaffected by either provision"), aff'd on other grounds, Budget Serv. Co. v. Better Homes, 804 F.2d 289, 293 n.4 (4th Cir. 1986).

${ }^{152}$ See Elder-Beerman Stores Corp. v. Thomasville Furniture Indus. (In re Elder-Beerman Stores Corp.), 197 B.R. 629, 632 (Bankr. D.Ohio, 1996). See also, In re Cont'l Air Lines, Inc., 61 B.R. 758, 775 n.35 (S.D. Tex. 1986).
} 
continue to exist because of an alternative source of authorization, is the scope of that authorization the same as 28 U.S.C. $\S 1481$ ? Would 28 U.S.C. $\S 1481$ authorize greater powers for bankruptcy courts than an alternative source of equitable powers? Or might 28 U.S.C. $\$ 1481$ place limits on bankruptcy courts equitable powers that would not otherwise exist, such as its limitation on the criminal contempt powers?

If 28 U.S.C. $\S 1481$ was never repealed, then it continues to provide statutory authorization for the equity powers of bankruptcy courts. Accordingly, the emphasis that many courts have put on other sections of the Bankruptcy Code, especially section 105(a), is unnecessary and misplaced, and has misdirected the debate about the scope of bankruptcy equity based on inapplicable statutory language, as discussed at length below. If 28 U.S.C. $§ 1481$ is still valid, then the limits of bankruptcy courts' equity powers are whatever 28 U.S.C. $§ 1481$ authorizes, limited only by Constitutional concerns.

If, on the other hand, 28 U.S.C. $§ 1481$ was repealed, as seems to be the case, it no longer provides a statutory authorization for the equity powers of bankruptcy courts. No replacement section was ever enacted. The awkward repeal of 28 U.S.C. $\S 1481$ raises several questions: Is there currently any textual authorization for bankruptcy courts equitable powers? If so, what limits does that textual authorization place on the exercise of equitable powers? If there is no valid textual authorization of bankruptcy courts' equitable powers, do these powers continue to exist? And in either case, might there be other non-textual limits on these powers? In other words, one way of determining the meaning of equitable powers is to probe their limitations, be they textual, Constitutional, prudential, or otherwise.

\section{Old Wine in New Vessels? 11 U.S.C. § 105(a)}

The House Committee Report on the 1978 Code noted that 28 U.S.C. $\S 1481$ was "in 
addition to any power granted under 28 U.S.C. $§ 1651$ (The All Writs Statute) or under section 105 of the Bankruptcy Code." ${ }^{153}$ Similarly, the Supreme Court indicated in Continental Illinois National Bank \& Trust v. Chicago, Rock Island \& Pacific Railway Co. ${ }^{154}$ that section 2(a)(15) of the 1898 Act and the All Writs Act (then codified at 28 U.S.C. § 262) ${ }^{155}$ were separate heads of judicial power distinct from a bankruptcy court's status as a court of equity as derived from section 2(a)(1) of the 1898 Act. $^{156}$ In Continental Illinois National Bank, the Court upheld a bankruptcy court's injunction against the enforcement of a lien on the sale of a debtor's bonds held as collateral by creditors. The Court held that " $[\mathrm{t}]$ he bankruptcy court, in granting the injunction, was well within its power, either as a virtual court of equity, or under the broad provisions of $\S 2[(\mathrm{a})](15)$ of the Bankruptcy Act or of $\S 262$ of the Judicial Code."157 Conceivably, there could be statutory authorization of the equity powers of the bankruptcy courts in these statutory sections. Section 105 of the 1978 Code, 11 U.S.C. $\S 105$, is a provision analogous to section 2(a)(15) of the 1898 Act. It currently ${ }^{158}$ provides:

(a) The court may issue any order, process, or judgment that is necessary or appropriate to carry out the provisions of this title. No provision of this title providing for the raising of an issue by a party in interest shall be construed to preclude the court from, sua sponte, taking any action or making any determination necessary or appropriate to enforce or implement court orders or rules, or to prevent an abuse of process.

(b) Notwithstanding subsection (a) of this section, a court may not appoint a receiver in a case under this title.

(c) The ability of any district judge or other officer or employee of a district court to exercise any of the authority or responsibilities conferred upon the court under this title shall be determined by reference to the provisions

\footnotetext{
${ }^{153}$ See H.R. REP. NO. 95-595, at 448 (1977), reprinted in U.S.C.C.A.N. 5963, 6404.

154294 U.S. 648 (1935).

15528 U.S.C. $§ 262$ (1934) (authorizing federal courts "to issue all writs not specifically provided for by statute, which may be necessary for the exercise of their respective jurisdictions").

${ }^{156} I d$. at 675.

${ }^{157} I d$. at 676.

${ }^{158}$ The second sentence of section 105(a) was added as part of the 1986 Amendments to the Code.

(C) 2006, Adam J. Levitin
} 
relating to such judge, officer, or employee set forth in title 28 . This subsection shall not be interpreted to exclude bankruptcy judges and other officers or employees appointed pursuant to chapter 6 of title 28 from its operation. ${ }^{159}$

Section 105(a), in particular, has become the provision usually cited as authorizing the equitable powers of the bankruptcy court. As one bankruptcy judge has noted, "Parties in interest in bankruptcy often call upon section 105 of Title 11 as a means of enlisting the aid of judicial authority whenever the Bankruptcy Code does not expressly address a particular situation.”160

As a matter of statutory interpretation, the support for section 105(a) as authorizing bankruptcy equity powers is weak. The word "equity" does not appear in section 105 . This is not an accidental omission. Congress used the word "equity" (in the sense of justice and not ownership) and "equitable" in fourteen distinct Code provisions. ${ }^{161}$ A general grant of equity powers in section 105(a) would render the Code's direction for the court to act in accordance with principles of equity in specific circumstances redundant.

By its terms, the first sentence of section 105(a) only authorizes the court to do whatever it finds "necessary or appropriate to carry out the provisions" of the Code. A plain language reading of section $105(a)^{162}$ would mean that section 105 (a) grants only the power to implement specific statutory sections and does not confer any substantive powers itself.

On the other hand, section 105(b) expressly prohibits a bankruptcy judge from appointing a receiver. ${ }^{163}$ Receivership is a traditional type of relief, so perhaps the exclusion of one type of

\footnotetext{
${ }^{159} 11$ U.S.C. $\S 105(\mathrm{a})(2000)$.

${ }^{160}$ Manuel D. Leal, The Power of the Bankruptcy Court: Section 105, 29 S. TEX. L. REV. 487, 489 (1988).

${ }^{161}$ See infra note 92.

${ }^{162}$ In re Cont'l Airlines, 203 F.3d 203, 211 (3rd Cir. 2000) (section 105(a) does not "create substantive rights that would otherwise be unavailable under the Bankruptcy Code."). Cf. Norwest Bank Worthington v. Ahlers, 485 U.S. 197, 206 (1988) ("whatever equitable powers remain in the bankruptcy courts must and can only be exercised within the confines of the Bankruptcy Code").

${ }^{163} 11$ U.S.C. $\S 105(b)(2000)$.
} 
equitable relief implies an authorization of others. Indeed, section 105 contains a much broader authorization than its predecessor section, section 2(a)(15) of the 1898 Act. As one bankruptcy court has observed,

Unlike the restriction under prior law that an order of a Bankruptcy Court must be "necessary for the enforcement of the provisions of this act," $\$ 105$ authorizes the Bankruptcy Court to also issue orders "appropriate to carry out the provisions of this title." 164

Thus, the phrase "provisions of this title" could be read to include the more general goals of specific provisions or even the general policy goals of bankruptcy. More expansive readings of section 105(a) are problematic, though, because the Code never speaks directly about its own purpose; the policy goals of the Code are only addressed in the legislative history, not in "the provisions of this title."

The second sentence of section 105(a), added in 1986, may provide an interpretive key to the first sentence. The second sentence was added as part of the 1986 amendments to the Code in order to provide clear authorization of sua sponte action by bankruptcy courts. ${ }^{165}$ If the second sentence of 105(a) is read as a gloss on, or clarification of, the first sentence, then the entire section looks like an authorization of judicial management and enforcement powers, not a grant of general equitable powers.

Indeed, the language of section 105(a) would be a strange way for Congress to have authorized something as important as general equitable powers. Reading section 105(a) as statutory authorization of any equitable powers of a bankruptcy court stretches the statutory language. Many courts and commentators, however, have taken section 105(a) as an explicit grant of equity power, ${ }^{166}$ which has then lead to a misplaced debate on the breadth of this

\footnotetext{
${ }^{164}$ In re Howell, 4 B.R. 102, 105 (Bankr. M.D. Tenn. 1980).

${ }^{165}$ See 132 Cong. Rec. S5092 (daily ed. Oct. 3, 1986).

${ }^{166}$ E.g., In re Stone \& Webster, Inc., 286 B.R. at 539; In re Wellman, 89 B.R. 880, 883 (Bankr. D. Colo.
} 
statutory grant of equity.

The legislative history makes the ascription of equity authorization to section 105(a) even more questionable. The House Committee Report insists that a bankruptcy court is a court of equity, but it does so in reference to 28 U.S.C. $\S 1481$, not 11 U.S.C. $§ 105{ }^{167}$ The legislative history of 28 U.S.C. $\S 1481$ itself refers to section 105 . The inference, however, is that 28 U.S.C. 1481 is the authorization of equity powers, whereas that 11 U.S.C. $\S 105$ is merely an enforcement provision like the All Writs Statute, ${ }^{168}$ much like sections 2(a)(1) and 2(a)(15) of the 1898 Act.

The House Committee Report's comments on section 105 indicate that subsection (a) was meant to clarify the extension of the All Writs Statute to bankruptcy courts. The House Committee Report noted:

Section 105 is similar in effect to the All Writs Statute, 28 U.S.C. 1651, under which the new bankruptcy courts are brought by an amendment to 28 U.S.C. 451 , H.R. $8200 \S 213[$, 95th Cong. (1977)]. The section is repeated here for the sake of continuity from current law and ease of reference, and to cover any powers traditionally exercised by a bankruptcy court that are not encompassed by the All Writs Statute. ${ }^{169}$

1988); In re Wilnor Drilling, Inc., 29 B.R. 727, 729-30 (S.D. Ill. 1982); Fed. Land Bank of St. Paul v. Brown (In re James), 20 B.R. 145, 149 (Bankr. E.D. Mich. 1982); Deborah A. Crabbe, Are Non-debtor Releases/Permanent Injunctions Authorized Under the Bankruptcy Code? 2003 AM. BANKR. INSTIT. J. LEXIS 94 (May 2003); David B. Stratton, Equitable Remedies in Bankruptcy Court: Grupo Mexicano, Substantive Consolidation and Beyond, 2003 AM. BANKR. INSTIT. J. LEXIS 39, at *3 (March 2003); Hon. Stephen A. Stripp, An Analysis of the Role of the Bankruptcy Judge and the Use of Judicial Time, 23 SETON HALl L. REV. 1330, 1360-68 (1993); Brian Leepson, Note and Comment, A Case for the Use of a Broad Court Equity Power to Facilitate Chapter 11 Reorganization, 12 BANKR. DEV. J. 775, 776, 793, 798 (1996); Jason A. Rosenthal, Note, Courts of Inequity: The Bankruptcy Laws' Failure to Adequately Protect the Dalkon Shield Victims, 45 FlA. L. REV. 223, 230-238 (1993); Adam J. Wiensch, Note, The Supreme Court, Textualism, and the Treatment of Pre-Bankruptcy Code Law, 79 GEO. L. J. 1831, 1861 (1991).

${ }^{167}$ See H.R. REP. NO. 95-595, at 359 (1977), reprinted in U.S.C.C.A.N. 5963, 6315.

16828 U.S.C. 1651 (2000). ("The Supreme Court and all courts established by Act of Congress may issue all writs necessary or appropriate in aid of their respective jurisdictions and agreeable to the usages and principles of law.”) 28 U.S.C. $§ 451$ (1982) (possibly repealed in 1984), a definitional section for the All Writs Statute, clarified that bankruptcy courts were included in the application of the All Writs Statute.

${ }^{169}$ H.R. REP. NO. 95-595, at 316-317 (1977). 
Thus, if section 105 is just a duplicative enactment of the All Writs Statute for bankruptcy courts, it is hardly an authorization of broad equity powers; at most it might authorize some equitable remedies such as injunctions for contempt and the issuance of the section 362 automatic stay. ${ }^{170}$

To read the All Writs Statute as authorizing the sort of equity powers that Justice Douglas wrote of in Pepper v. Litton taxes the statutory language. In the context of a statutory scheme, the All Writs Statute is an enforcement provision, as the Supreme Court has noted,

Where a statute specifically addresses the particular issue at hand, it is that authority, and not the All Writs Act, that is controlling. Although that Act empowers federal courts to fashion extraordinary remedies when the need arises, it does not authorize them to issue ad hoc writs whenever compliance with statutory procedures appears inconvenient or less appropriate. ${ }^{171}$

The All Writs Statute does not authorize courts to operate according to "the principles and rules of equity jurisprudence," nor does it authorize courts to look to substance over form so that "technical considerations will not prevent substantial justice from being done."172

Moreover, if section 105(a) is merely a duplicative version of the All Writs Statute, it is hard to see what if anything makes bankruptcy a "court of equity" in a sense unique enough from other federal courts that it bears comment. If 105(a) and the All Writs Statute are the source of equity powers, then all federal courts are "courts of equity." The repeated and insistent use of this phrase by courts in reference to bankruptcy courts indicates that there is something that makes bankruptcy courts different from other federal courts by virtue of being courts of equity. Article III courts are authorized to hear cases "in Law and Equity."173 Indeed, other federal courts, such as the Tax Courts, regularly look to the substance of transactions instead of their

\footnotetext{
17011 U.S.C. $\$ 362$ (2000).

${ }^{171}$ Pa. Bureau of Corr. v. U.S. Marshals Serv., 474 U.S. 34, 43 (1985).

172308 U.S. at 304-305.

${ }^{173}$ See U.S. CONST. art. III, §. 2.
} 
form, ${ }^{174}$ as a matter of federal common law, even if the form complies with the technical requirements of the statutory scheme of the Internal Revenue Code. Yet, no one would ever think to refer to the Tax Courts as "courts of equity." Thus, being a court of equity must mean something more than just looking to substance over form. Arguably, as we shall see, it means something more akin to pursuing "substantial justice" or fairness, which may involve deviations from a well-defined statutory system.

Neither the All Writs Statute nor the statutory language of section 105(a) authorize equity powers for bankruptcy courts. The current statutory authorization of general bankruptcy equity powers is highly questionable. Nonetheless, many courts cling to section 105(a) as an authorization of bankruptcy court's general equity powers, which has led to questionable rulings both for and against various non-Code practices.

\section{Square Pegs in Round Holes: The Problems Created by locating Bankruptcy EQUiTy POWERS IN SECTION 105(A)}

Even though an examination of the history of the 1978 Bankruptcy Code indicates that section 105(a) was not intended to authorize or limit bankruptcy courts' equitable powers, and does not even refer to them one way or the other, it has filled courts' need for a statutory touchstone for the authorization of equitable powers in bankruptcy. Courts like to have statutory authorization for their actions. Clear statutory directives allow judges to avoid having to make hard decisions or value judgments and allow for easy appellate review. Statutory directives allow courts to resolve the tension that exists in bankruptcy between the adjudicative methods of equity and statute.

Unfortunately, the language of section 105(a), drafted as an enforcement provision, and

\footnotetext{
${ }^{174}$ See Comm'r. v. Court Holding Co., 324 U.S. 331, 334 (1945). Similarly, the economic analysis of law so en vogue with some judges over the last couple of decades is precisely an analysis of economic substance instead of legal form, yet no one would think to term this equitable analysis.
}

(C) 2006, Adam J. Levitin 
possibly intended to ratify bankruptcy courts' pre-Code powers, now bears the weight of significantly more expansive powers. Section 105(a) has become the frame of judicial reference for, and, inevitably, a limitation on, equitable powers whose source was never in its statutory language. Using an inappropriate statutory provision as a stand-in talisman for an actual provision dealing with bankruptcy equity has led to a variety of bad or questionable decisions and misplaced debates about the scope of bankruptcy courts' equity powers, about the way those powers are to be applied, and about the propriety of a variety of non-Code practices.

The language of section 105(a) has led several courts to reject non-Code practices normally authorized under the equitable powers of a bankruptcy court. These courts have held that section 105(a) only gives the power to implement other sections of the Bankruptcy Code, and is not authorization of substantive powers.

\section{First Day Orders: Capital Factors, Inc. v. K-Mart Corp.}

In Capital Factors, Inc. v. K-Mart Corp., the Northern District of Illinois reversed the bankruptcy court's "first day order" that authorized pre-plan payments to "critical" vendors for pre-petition obligations, another non-Code practice. ${ }^{175}$ The district court rejected arguments that the payments were statutorily authorized under section 105(a) powers or were otherwise equitably permitted under the equitable doctrine of necessity. ${ }^{176}$

The District Court found that the doctrine of necessity could be applied only through

${ }^{175}$ Capital Factors, Inc. v. K-Mart Corp., 291 B.R. 818 (N.D. Ill. 2003).

${ }^{176} I d$. The doctrine of necessity developed in equity receiverships for railroads. See, e.g., In the Matter of $B \& W$ Enters., Inc., 713 F.2d 534, 536-37 (9th Cir. 1983). It is actually an amalgam of two rules from equity receiverships for railroads, the Six Months Rule and the Necessity of Payments Rule. See id.; see also In re CoServ, L.L.C., 273 B.R 487, 492 n.7 (Bankr. N.D. Tex. 2002). See B \& W Enters., 713 F.2d at 536-37. Only the Six Months Rule has been incorporated in the Bankruptcy Code at 11 U.S.C. 1171(b) (2000) and only for railroad reorganizations. See id.; see also CoServ, 273 B.R at 492 n.7. But see KMart 291 B.R. at 822 ("The doctrine [of necessity] is not codified anywhere in the Bankruptcy Code....") (emphasis added). 
section $105(\mathrm{a}),{ }^{177}$ but "the grant of equitable power in $\S 105$ is limited in that it 'allows [bankruptcy] courts to use their equitable powers only as necessary to enforce the provisions of the Code, not to add on to the Code as they see fit." 178 The district court also cited a Seventh Circuit case, In the Matter of Chicago, Milwaukee, St. Paul, and Pacific Railroad Corp., ${ }^{179}$ decided under the 1898 Act, in which Judge Posner wrote:

the fact that a proceedings is equitable does not give the judge a free-floating discretion to redistribute rights in accordance with his personal views of justice and fairness, however enlightened those views may be. ${ }^{180}$

The K-Martdistrict court noted that the effect of allowing pre-plan payments to certain creditors would be "to elevate the claims of the 'critical' vendors over those of other unsecured creditors and to subordinate the claims of non- 'critical' unsecured creditors." ${ }^{\prime 181}$ The problem, as the district court saw it, was that " $[\mathrm{t}]$ he bankruptcy court altered the priority scheme set forth in the Bankruptcy Code.",182

The difficulty with "critical vendor motions" and "first day orders" is that even if they deviate from the Bankruptcy Code's priority scheme, they can be necessary to preserve the value

\footnotetext{
${ }^{177}$ Id. at 822 .

${ }^{178} I d$.

${ }^{179}$ In the Matter of Chi., Milwaukee, St. Paul, and P. R.R. Comp., 791 F.2d 524 (7th Cir. 1986). See infra text accompanying notes 215-221 for a discussion of this case. Curiously the district court failed to cite another equally binding case decided under the 1898 Act, In re Kane, 127 F. 552 (7th Cir. 1904), in which the Seventh Circuit affirmed a district court bankruptcy decision that had allowed a debtor to use his state law exemption but not according to the procedures required at state law. The Kane court declared in no uncertain terms that "A court of bankruptcy is a court of equity, seeking to administer the law according to its spirit, and not merely by its letter." Id. at 553.

${ }^{180} 291$ B.R. at 823 (internal citation omitted.).

${ }^{181} I d$. at 822 . The concern over pre-plan payments is potentially two-fold. First, it elevates the claims of "critical" vendors over those of other unsecured creditors, functionally subordinating the "non-critical" unsecureds to the "critical" unsecureds. Second, paying off pre-petition claims pre-plan often incurs "more senior debt at the expense of unpaid unsecured creditors, since [the] secured, super-priority, postpetition loan will increase concomitantly with the amounts paid [to the critical vendors]" subordinating "non-critical" unsecureds to the DIP lender for a greater amount. See CoServ, 273 B.R. at 496.

182291 B.R. at 823. The passage of a year between K-Mart's bankruptcy filing and the district court's decision cast also question on the "critical" nature of any vendor and hence the necessity of confirming the order.
} 
of the estate for the benefit of the creditors as a group. The Code's priority scheme ${ }^{183}$ deals with the priority of distributions at the time of a plan. Critical vendor motions, however, deal with pre-plan payments. In some cases, a pre-plan payment to select creditors at time one allows other creditors to receive a larger recovery at time two, under a plan, than if there had been no pre-plan payment. Of course, if creditors do not think that the plan will work, this logic does not apply, as creditors do not want good money chasing bad. The irony is that creditor actions to prevent critical vendor motions because of a lack of confidence in a reorganization's success often become self-fulfilling prophecies because the debtor is unable to continue operations while in bankruptcy and must liquidate.

Insisting on the Code's priority scheme in some circumstances fails to recognize the practical limitations of courts' power under the automatic stay and can actually harm the net estate. Consider a situation in which the debtor has significant property outside of the United States, say an $\$ 80$ million oil rig in the North Sea. ${ }^{184}$ Among the debts that the debtor owes is a \$2 million repair bill for work done by a British oil service company without any assets in the United States. As a practical matter, the automatic stay of section $362^{185}$ cannot be enforced against the oil rig service company if it seizes the oil rig under English law.

Thus, unless the oil rig service company is paid in full, up front, it will seize the rig. In these circumstances, following a narrow interpretation of the Code will deprive the bankruptcy estate of an $\$ 80$ million, revenue-producing asset on account of a $\$ 2$ million debt. Creditors value principles much less than principal. Insisting on the letter of the Code defeats its purposes. A first day order permitting the pre-plan payment of a pre-petition debt to the oil service company will actually protect value for other creditors and assist in the rehabilitation of the

183 11 U.S.C. $\$ 507$ (2000).

${ }^{184}$ Many thanks to Martin Bienenstock of Weil, Gotshal \& Manges, LLP for this scenario.

18511 U.S.C. $\S 362$ (2000). 
debtor. A deviation from the priority scheme of section $507^{186}$ at the beginning of the bankruptcy is necessary to effectuate section 362's protection of estate property, and increase the asset pool available for distribution under a plan.

The difficulty that bankruptcy courts face, however, is distinguishing between sensible first day order requests, like with the oil rig, and preferential treatment of favored creditors that does not benefit the estate. Often, all the court has to go on in ruling on first day order motions is the uncorroborated testimony of the debtor's attorney or an officer of the debtor. This creates a great potential for abuse of critical vendor motions. Cronies of a debtor's CEO who are also creditors and vendors that are not "critical" can both get favored treatment and circumvent the Code's priority system.

For example, in Capital Factors, Inc. v. K-Mart Corp., there were no less than 2,330 “critical” vendors ${ }^{187}$ for whom K-Mart requested a "\$300 million slush fund." 188 The number of critical vendors seems excessive, although the business model for "mart" stores like K-Mart is to carry a huge variety of products and offer one-stop shopping. Even if only ten percent of the critical vendors actually withheld future shipments unless paid pre-plan for pre-petition obligations, the withholding would devastate a "mart" debtor's operations. The reputational hit of bankruptcy to a store like K-Mart is significant, but poorly stocked shelves during the pendency of the bankruptcy would hurt the prospects for a successful reorganization even more. K-Mart could probably do without most individual vendors, but this is beside the point. For a "mart," the issue is not which individual vendor is critical, but a critical mass of suppliers.

This raises the question, then, of how to separate out the "critical" vendors who will

186 11 U.S.C. $\$ 507$ (2000).

${ }^{187}$ In re Kmart Corp., 359 F.3d 866, 869 (7th Cir. 2004).

${ }^{188}$ LYNN M. LOPUCKI, COURTING FAILURE: HOW COMPETITION FOR BIG CASES IS CORRUPTING THE BANKRUPTCY COURTS 134 (Ann Arbor: Univ. of Michigan Press, 2005).

(C) 2006, Adam J. Levitin 
ultimately continue to supply the debtor without pre-plan payment of pre-petition obligations from those who will not. Requiring testimony is simply impractical, as there is no time for a serious evidentiary hearing lasting weeks in the case of a large "mart" debtor. Yet merely taking the debtor's word seems insufficient. A court could require the vendors to produce affidavits that unless paid pre-plan for pre-petition debts, they will cease further supply, but what does this really accomplish? Such affidavits could only be procured in time for a bankruptcy filing by informing all the vendors of the impending filing, which can hurt the debtor, as the vendors will likely cease supply immediately. Moreover, it would be too easy of a system to game and would result in pro forma affidavits from most vendors. Once the gate of critical vendor motions is opened, it cannot be shut. The bankruptcy court cannot practically serve as gatekeeper. Allowing the debtor to serve as gatekeeper, though, invites abuse of the bankruptcy process.

\section{a. Regulatory Capture and the Bankruptcy Courts?}

The critical vendors motion in K-Mart forced the Seventh Circuit to deal with a regulatory agency capture problem. "Capture" is the term used to describe the domination of a government regulatory agency by the interests of the industry that it oversees. There are no agencies with rule-making power in bankruptcy. In this sense, bankruptcy is unique among areas of federal law. The Office of the United States Trustee does not have rule-making power for the bankruptcy system. The Judicial Conference makes Bankruptcy Rules, but these operate quite differently than, say, regulations promulgated by the EPA; Bankruptcy Rules, like the Federal Rules of Civil Procedure, are essentially procedural. Bankruptcy courts, however, do fill some of the roles of an administrative agency, and the interests they regulate are primarily debtors. And, although, bankruptcy judges work as individuals, they can be seen as operating as collectives for certain purposes, at least within districts. 
In a provocative book, Lynn M. LoPucki has argued that certain judicial districts, including the Northern District of Illinois, have consciously become debtor-friendly venues in order to attract a greater share of large corporate bankruptcy filings. ${ }^{189}$ A debtor can file for bankruptcy in any district in which the debtor or any of its affiliates is incorporated. Debtorfriendly actions that a court can take include approving large attorneys' fees, allowing payment of attorneys' fees on a monthly, rather than a quarterly, basis, approving director-and-officer liability releases, refusing to appoint trustees-in-bankruptcy, and granting first-day motions and critical vendor orders.

Bankruptcy judges, according to LoPucki, have done this for prestige, power, and celebrity that come from managing large cases. ${ }^{190}$ They also do so to please the local bar in order to assure reappointment. ${ }^{191}$ Most importantly, though, they have done so because they are acutely conscious of the economic impact of filings on their district. A large bankruptcy case, lasting two years or so, and involving dozens, if not hundreds of lawyers, paralegals, secretaries, etc., can bring employment and tremendous revenue to the local bankruptcy bar. ${ }^{192}$ It also provides a boon to the local economy through hotel, restaurant, and transportation fees. For a small city like Wilmington, Delaware, for example, the courts play a major role in the local economy. Moreover, districts with particularly heavy caseloads are more likely to receive additional judgeships from Congress.

Districts marketing themselves as debtor-friendly venues raises questions of what sort of measure of discretion should be allowed and what sort of review should be undertaken of decisions. Judicial review is complicated because, according to LoPucki, not only bankruptcy

\footnotetext{
${ }^{189} \mathrm{Id}$. at $133-35$.

${ }^{190} \mathrm{Id}$. at 20.

${ }^{191} I d$. at $20-21$.

${ }^{192} I d$. at 21.
} 
judges, but also district judges are complicit in making debtor-friendly forums. The typical response to agency capture is to raise transaction costs on the agency's doing business.

In the bankruptcy court context, raising transaction costs is not as simple as raising them on agencies. For agencies, it often involves requiring more extensive documentation of reasoning behind decisions, greater delay in decision-making, greater notice to the public, and more opportunities for public feedback. Raising transaction costs on bankruptcy courts is not possible or advisable. The Bankruptcy Code already contains extensive notice and hearing provisions, ${ }^{193}$ and there is little that can be done to increase these requirements. Procedures that impose delay on bankruptcy court decisions are contrary to the interests of both creditors and debtors, as the quick resolution of a bankruptcy is generally in the interest of the debtor and most creditors. Time-value of money accrues during the course of a bankruptcy proceeding, but unsecured creditors may not include post-petition interest in their claims, ${ }^{194}$ at least when the debtor is insolvent, and secured creditors have a claim for post-petition interest only up to the value of their collateral. ${ }^{195}$

The only obvious way to raise transaction costs on bankruptcy courts is to require more extensive documentation of supporting facts. Judge Easterbrook's ruling in K-Martcan be seen as a public choice theory response to abuse of judicial discretion. The Seventh Circuit still allows first day orders and critical vendor motions, but it requires better evidentiary documentation of the need for the orders. In theory, increased documentation raises the cost of issuing such orders on the court (the regulator) and raises the cost of acquiring such orders on the

\footnotetext{
${ }^{193}$ See, e.g., 11 U.S.C. $\S \S 363$ (b)(1) (sale of property other than in the ordinary course of business after notice and hearing), 363(c)(2) (use, sale, or lease of cash collateral requires notice and hearing), 503(b) (notice and hearing required for allowance of administrative expenses) (2000).

19411 U.S.C. § 502(b)(2); United Sav. Assoc. of Tex. v. Timbers of Inwood Forest Assocs. Ltd., 484 U.S. 365, 372-73 (1988).

19511 U.S.C. $§ 506(b)$ (2000).
} 
debtor (the equivalent of the regulated entity).

The problem with the public choice response in bankruptcy is that in bankruptcy practice, it is not the courts, but the moving party that typically drafts an order. Thus, requiring better evidentiary documentation would simply transfer the costs of motions onto the moving parties, rather than requiring the court to document more facts. To the extent that the regulated entity, the debtor, is the moving party, there is even less deterrence against court capture because the debtor is not playing with its own money. Additional legal expenses involved in procuring first day orders are administrative expenses of the bankruptcy estate ${ }^{196}$ and are at the top of bankruptcy's priority tree. ${ }^{197}$ In the typical bankruptcy in which all creditors do not recover 100 cents on the dollar, any increased costs in critical vendor motions are borne by the unsecured creditors who do not have administrative expense claims. Thus, the debtor's ability to play with creditor money only amplifies the traditional criticism of public choice theory response to regulatory capture, namely, that increasing the costs on regulatory changes only exacerbates the relative resource disparities between regulated parties (which have an incentive to apply a large share of their resources to lobbying for favorable regulation) and the public at large, in this case the debtor and its unsecured creditors.

Thus, increased evidentiary requirements like the Seventh Circuit's in K-Mart are likely themselves do little to combat court capture. The Seventh Circuit has, however, with a string of opinions, made itself an affirmatively unfriendly circuit for debtors; unfortunately, circuit splits on critical vendor motions only exacerbate the problem of court capture, by making debtorfriendly circuits even more appealing. In the years leading up to $-K$-Mart the Northern District of Illinois had become a major contender for large Chapter 11 filings. Notably, no "mega"

196 11 U.S.C. $\$ 503(\mathrm{~b})(4)(2000)$.

19711 U.S.C. $\$ 507(\mathrm{a})(1)(2000)$.

(C) 2006, Adam J. Levitin 
bankruptcy cases have been filed in the Seventh Circuit since the K-Mart critica 1 vendors decision. ${ }^{198}$

\section{b. K-Mart's Statutory Approach to the Capture Problem}

In K-Mart the district court did not consider the policy problems of capture. Nor did it consider the practical business and administrability concerns that complicate critical vendor motions, even though two of the four motions challenged in K-Mart dealt with foreign vendors, who present the strongest case for the necessity of authorizing pre-plan payments of pre-petition obligations to protect value for the estate. ${ }^{199}$ Instead, the district court in $K$-Mart turned the issue into a matter of statutory interpretation of section 105(a). The district court viewed section 105(a) as the locus of the equitable powers of the bankruptcy court. Accordingly, the powers were limited by the language of section 105 (a) as well as by the systemic jurisprudential concerns about judicial lawmaking in the face of Congress' express priority scheme in the Code.

For the district court in K-Mart, the Code did not just place specific limitations on general equitable powers, but defined the outer limit of those powers. Exactly what room is left for equity is not spelled out; $K$-Martraises the question of what it means for bankruptcy to be a proceeding in equity when there is no room for a court to exercise the discretion of equity beyond what is allowed in any other proceeding. Does bankruptcy equity have any meaning?

The Seventh Circuit did little to answer this question when it took up K-Mart on appeal. Writing for the court, Judge Easterbrook declared that section 105(a) "does not create discretion to set aside the Code's rules about priority and distribution; the power conferred by section

\footnotetext{
198 See LoPUCKI, supra note 188, at 133-35. Ironically, LoPucki notes that lawyers say that the Chicago bankruptcy courts lack "predictability" because of the Seventh Circuit's failure to approve of non-Code practices unconditionally. Id. at 134.

${ }^{199}$ See supra discussion accompanying notes 184-186.
}

(C) 2006, Adam J. Levitin 
105(a) is one to implement rather than override." ${ }^{200}$ Judge Easterbrook declaimed:

A 'doctrine of necessity' is just a fancy name for a power to depart from the Code....Older doctrines may survive as glosses on ambiguous language enacted in 1978 or later, but not as freestanding entitlements to trump the text. ${ }^{201}$

As Judge Easterbrook would have it, the only possible role for equitable practices is to decide ambiguous statutory language. This is hardly something unique to bankruptcy; courts regularly weigh equities in any situation involving ambiguous statutory language. What, if anything, then does it mean for bankruptcy to be a "proceeding in equity"? Is it merely a tip of the hat to bankruptcy's historical origins? Or might it have more substantial meaning, such as a mandate to do equity?

2. Pre-Plan Payments of Pre-Petition Debts: Official Committee of Equity Security Holders v. Mabey

The Fourth Circuit's decision in Mabey ${ }^{202}$ vividly posed that very question. Mabey was an appeal from a district court's confirmation of a bankruptcy court order under section 105(a) directing the pre-plan establishment of an emergency fund for women injured by Dalkon Shield inter-uterine devices (IUDs). The Fourth Circuit held the order violated the Code's pro-rata distribution scheme by effecting a pre-confirmation distribution, even though the disbursement would be deducted from what the claimants would otherwise receive and would go directly to doctors for treatment to prevent irreparable damage to the women's reproductive ability. ${ }^{203}$ The doctrine of necessity played no role in the Fourth Circuit's decision. There were no critical vendors and no potential tangible benefit to the estate from the payments. The situation was critical for the tort victims, not for the debtor. There was a risk that by paying the tort victims

\footnotetext{
${ }^{200}$ In re Kmart Corp., 359 F. 3d 866, 871 (2004).

${ }^{201} I d$.

${ }^{202}$ Official Comm. of Equity Sec. Holders v. Mabey, 832 F.2d 299 (4th Cir. 1987), cert. denied, 485 U.S. 962 (1988).

${ }^{203}$ Id. at 300 .
}

(C) 2006, Adam J. Levitin 
earlier they might get a windfall if at the time of distribution under the plan there would not be enough assets in the estate to satisfy other creditors claims. But there was also the possibility that the estate's value at distribution would be greater than anticipated. The Fourth Circuit did not consider any of this or weight the competing equities. Under the Bildisco balancing principle, though, the weight of the equities was clear-cut.

The Fourth Circuit took a facially more generous approach to equitable powers than the district court in $K$-Mart Rather tha n saying that the equitable powers of a bankruptcy court are solely to enforce the Code, the Fourth Circuit, anticipating Ahlers, held that equity power could be wielded, but only when it did not contradict the Code:

While the equitable powers emanating from $\S 105(a)$ are quite important in the general bankruptcy scheme, and while such powers may encourage courts to be innovative, and even original, these equitable powers are not a license for a court to disregard the clear language and meaning of the bankruptcy statutes and rules.... 204

As the Fourth Circuit applied its standard,

the creation of the Emergency Treatment Fund at this stage of the Chapter 11 bankruptcy proceedings violates the clear language and intent of the Bankruptcy Code, and such action may not be justified as an exercise of the court's equitable powers under $105(\mathrm{a}){ }^{205}$

The Fourth Circuit did not try particularly hard to avoid a conflict between the bankruptcy court's exercise of its equitable powers and the Code. The Mabey opinion did not point to the "clear language" of the Code that the bankruptcy court disregarded. There is nothing in the Code that states that there may not be any payment before a plan; instead the Fourth Circuit inferred this from the provisions of sections 1121-29 providing for the filing and confirmation of a plan

\footnotetext{
${ }^{204}$ Id. at 302. The Ninth Circuit adopted a similar position in American Hardwoods. It noted that "[w]hile endowing the court with general equitable powers, section 105 does not authorize relief inconsistent with more specific law," and then proceeded, as in Mabey, to find the equitable relief granted inconsistent with the Code. 885 F.2d at 625.

${ }^{205}$ Mabey, 832 F.2d at 302.
} 
and from Bankruptcy Rule 3021, entitled "Distribution under Plan."206 By its terms, however, Rule 3021 says nothing about pre-plan distribution and need not be read to exclude it. ${ }^{207}$ There is no reason that the Fourth Circuit had to infer a ban on pre-plan distributions from a Bankruptcy Rule that speaks of distributions under a plan. The statutory scheme itself gave ample wiggle room, had the Fourth Circuit desired to take it. Instead, the Fourth Circuit looked for specific statutory authorization, because it did not have confidence that its equity powers could themselves be the authorization. What bears emphasis is that while Mabey would be the correct outcome in a strict statutory regime, bankruptcy is different because it is supposed to apply the statutory scheme with equitable considerations in mind.

One might compare the result in Mabey with that in In re CoServ, L.L.C. ${ }^{208}$ where Bankruptcy Judge Lynn of the Northern District of Texas used the notoriously ill-defined concept of fiduciary duties to rule that a critical vendor order was required by the Code. ${ }^{209}$ Judge Lynn held that "Claims May be Paid if Necessary to Performance of the Debtor in Possession's Fiduciary Duty," which includes the duty to "protect and preserve the estate, including an operating business's going-concern value."210 As Judge Lynn explained,

There are occasions when this duty can only be fulfilled by the preplan satisfaction of a prepetition claim....In such instances it is only logical that the bankruptcy court be able to use Section 105(a) of the Code to authorize satisfaction of the prepetition claim in aid of the preservation or enhancement of the estate. ${ }^{211}$

\footnotetext{
${ }^{206} I d$. have been allowed.").

208273 B.R 487 (Bankr. N.D. Tex. 2002).

${ }^{209} \mathrm{Id}$. at 496-97.

${ }^{210} I d$. (citing 11 U.S.C. $\left.\S \S 704,1106(2000)\right)$.

211273 B.R. at 497.
}

207 FED. R. BANKR. PROC. 3021 (1987) (“After confirmation of a plan, distribution shall be made to creditors whose claims have been allowed, to holders of stock, bonds, debentures, notes, and other securities of record at the time of commencement of distribution whose claims or security interests have not been allowed and to indenture trustees who have filed claims pursuant to Rule 3003(C)(5) and which 
If there is a will, judicial creativity knows few limits.

Given the lack of an explicit conflict with a statutory prohibition, the bankruptcy court's order Mabey hardly seems an abuse of its equitable powers under the Fourth Circuit's standard. If the plight of women whose reproductive ability ${ }^{212}$ would be irreparably damaged without immediate medical care does not cry out for the use of equitable powers when there is not a necessary conflict with the Code, it is hard to imagine what would. Certainly, the Fourth Circuit did not suggest any scenario. Functionally, Mabey, like the $K$-Martdecisions, leaves virtually no room for equity in bankruptcy beyond a court's normal powers to enforce and implement statutory provisions. Mabey is entirely inconsistent with Justice Douglas's explanation in Pepper v. Litton that, as a court of equity, a bankruptcy court was to ensure that "technical considerations" did not stand in the way of "substantial justice." By reading section 105(a) to be the authorization of bankruptcy court's equitable powers, the Fourth Circuit in Mabey avoided doing equity on account of an arguably inapplicable statutory limitation.

3. Division of a Limited Pot: In the Matter of Chicago, Milwaukee, St. Paul, and Pacific Railroad Corp.

K-Mart and Mabey were both concerned about upsetting the Code's priority scheme. But the Code's priority scheme is affected not just by the timing of payments, but also by any change in the size of the pot available for distribution or the number of claims. The priority scheme of section 507 is in many ways the heart of the Code, but if it is inviolate, it is hard to see what room is left for equity within the Code other than its fourteen specific directives. ${ }^{213}$ On the other hand, as Judge Posner observed in Chicago, Milwaukee, creating a fair and equitable

\footnotetext{
${ }^{212}$ It is worthwhile noting that reproductive ability has special constitutional significance. See Skinner v. Ok. 316 U.S. 535 (1942) (heightened equal protection and due process scrutiny when reproductive ability is at stake).

${ }^{213}$ See supra note 92.
} 
distribution of a limited pot is exactly what bankruptcy courts are supposed to do:

[t]he function of equitable considerations in a bankruptcy proceeding is to guide the division of a pie that is too small to allow each creditor to get the slice for which he originally contracted. ${ }^{214}$

Chicago, Milwaukee was decided in the aftermath of a successful reorganization of a solvent railroad under Section 77 the Bankruptcy Act of 1898; it did not involve a pre-plan payment to critical vendors or the doctrine of necessity. The Seventh Circuit upheld the district court's refusal to exercise its discretionary equitable powers under section 2(a)(15) of the Act to decelerate the principal on a defaulted 100-year debenture with an acceleration clause because in a solvent bankruptcy a creditor should get the full benefit of his bargain. In this case, the debenture indenture's acceleration clause was part of the bargain made in the shadow of bankruptcy, so there was no inequitable windfall to the debenture holders, as all other creditors received 100 cents on the dollar. ${ }^{215}$

\footnotetext{
214791 F.2d at 528.

${ }^{215}$ In Chicago, Milwaukee the railroad-debtor had issued 100-year debentures, which would pay 5\% per annum, if there were available net income, with the principal to be repaid at the end of the term. Id. at 525-26. After the railroad filed for bankruptcy, the indenture trustee declared the debentures in default. $I d$. at 526. (It is not clear from the opinion if the default was simply the filing for bankruptcy-an ipso facto clause, permitted under the Act, unlike under the Code - or if there was a monetary default.) By the terms of the indenture, this accelerated the debentures to becoming immediately payable in full. The acceleration raised issues of how to value the debenture holders' claims, particularly in regard to what interest rate to use to calculate present value and what to do for years for which there was no way of predicting if there was available net income on which the 5\% interest payment was contingent.

The debtor had appealed, arguing that the district judge should have decelerated the debentures. While the debenture holders did not challenge the district judge's power to decelerate, id., the Seventh Circuit upheld the district judge's decision, because the debtor was solvent, not because deceleration would have been an abuse of equitable power. Id. at 527. Indeed, Judge Posner noted that "The only good reason for refusing to give a creditor in reorganization all that he bargained for when he extended credit is to help other creditors, the debtor's assets being insufficient to pay all creditors in full." Id.

Creditors, of course, bargain in light of bankruptcy, which includes both the Code's priority scheme and the court's section 105(a) powers, including the possibility of a deviation from the priority scheme. In any case, unsecured creditors can hardly claim a reliance interest on their priority, as they usually have no way of knowing what sort of haircut to expect because they do not know the debtor's assets and liabilities.
} 
The Fourth Circuit in Mabey ${ }^{216}$ as well as the district court ${ }^{217}$ and the Seventh Circuit ${ }^{218}$ in K-Martcited a the sentence from Chicago, Milwaukee as authority for their limitation of section 105(a) powers:

The fact that a proceeding is equitable does not give the judge a free-floating discretion to redistribute rights in accordance with his personal views of justice and fairness, however enlightened those views may be. ${ }^{219}$

When this sentence is read in context, however, it is apparent that Judge Posner was saying something quite different.

Rather than saying that equitable considerations cannot affect the distribution scheme, Judge Posner was saying that there is room for equitable discretion when the debtor is insolvent and creditors cannot be paid 100 cents on the dollar, the situation in most bankruptcies:

The fact that a proceeding is equitable does not give the judge a free-floating discretion to redistribute rights in accordance with his personal views of justice and fairness, however enlightened those views may be. The function of equitable considerations in a bankruptcy proceeding is to guide the division of a pie that is too small to allow each creditor to get the slice for which he originally contracted. Hence if the bankrupt is solvent[,] the task for the bankruptcy court is simply to enforce creditors' rights according to the tenor of the contracts that created those rights; and one of those rights in this case was the right to accelerate the repayment of principal. ${ }^{220}$

Just as the statutory authorization of bankruptcy courts' equitable powers is questionable, so too is the case law authority upon which Mabey and K-Martrelied for limiting bankruptcy equity. ${ }^{221}$

\footnotetext{
${ }^{216}$ Mabey, 832 F.2d at 302. There is a certain irony to this miscitation, as in Mabey, the Fourth Circuit called the district court to task for citing an authority that did not speak to the issue. $I d$.

${ }^{217}$ K-Mart 291 B.R. at 832.

${ }^{218}$ In re Kmart Corp., 359 F.3d at 871.

219791 F.2d at 528 .

${ }^{220} I d$.

${ }^{221}$ Judge Posner's own authority for Chicago, Milwaukee is questionable-he cites a concurrence he authored, Piper Aircraft Corp. v. Wag-Aero, Inc., 741 F.2d 925 (7th Cir. 1984) (Posner, J., concurring) and an opinion that he authored, Shondel v. McDerMott, 775 F.2d 859 (7th Cir. 1985) (Posner, J.) and that cites the Piper Aircraft as authority. In both the opinion and concurrence, Judge Posner held forth on the nature of equity and its scope in the merged courts of law and equity, but only regarding non-bankruptcy contexts.
} 
Unfortunately, those decisions themselves are part of the body of case law now cited in support of limiting non-Code practices in bankruptcy.

4. Unraveling Authority: The Questionable Case Law Basis for a Limited Reading of Section 105(a) Powers

Curiously absent from the opinions of most courts that have declared that section 105(a) is only an enforcement power is an articulated textual or policy reason for such a reading. Instead, most decisions merely cite the sweeping declarations of earlier opinions, which themselves, cite declarations from still earlier opinions. When one traces back these chains of authority, however, the thread unravels, as is the case with Chicago, Milwaukee line of citation. Frequently, the original opinions from which declarations about the scope of bankruptcy equity derive deal with very different contexts and issues and were written in the context of different statutory authorization. Even then, the opinions rarely discuss the textual, policy, and prudential concerns that favor limiting the scope of bankruptcy courts' equitable powers through the language of section $105(\mathrm{a})$.

Perhaps courts consider the issue so self-evident that discussion of textual or policy considerations in not merited, but given the frequency with which section 105(a) arises, this is surprising. More likely, what lies behind courts' unwillingness to grapple with what section 105(a) and equity might actually mean is a sense of unease about judicial discretion, particularly in the context of Code-based systems. Although judicial lawmaking is certainly commonplace, some judges, conscious of their position as unelected, politically unaccountable figures, are uncomfortable with judicial lawmaking. Moreover, even judges who do not have such qualms might be uncomfortable with writing on a blank slate and would prefer to exercise discretion within guidelines. Bankruptcy frequently presents an even greater challenge because exercises of discretion are particularly hard in cases that present purely monetary rather than moral issues. 
A chain of Fifth Circuit decisions illustrates the process through which the slogans that now serve as authority for limiting the equity powers of bankruptcy courts under section 105(a) have become divorced from their unusual original (and arguably limiting) contexts. When one examines the context of the origins of these slogans, their wide-applicability is questionable, especially as they often serve as a proxy for consideration of the statutory and policy limitations on bankruptcy equity.

The most recent case in this chain of questionable Fifth Circuit cases is In re Mirant Corp. ${ }^{222}$ In Mirant, the bankruptcy court enjoined the Federal Energy Regulatory Commission (FERC) from taking any action to force the debtor power company to comply with its unprofitable governmentally-regulated contracts. The district court overruled the injunctions ${ }^{223}$ and on appeal, the Fifth Circuit held that the injunctions were impermissible because they were overbroad. ${ }^{224}$ Notably, the Fifth Circuit affirmed that a bankruptcy court's section 105(a) powers permit it to enjoin a federal regulatory agency. ${ }^{225}$

Before reaching this conclusion, the Fifth Circuit emphasized that:

A court's powers under $\S 105$ (a) are not unlimited as that section only "authorizes bankruptcy courts to fashion such orders as are necessary to further the substantive provisions of the Code," and does not permit those courts to "act as roving commissions to do equity."226

Yet, the Fifth Circuit acknowledged that a more narrowly tailored injunction in furtherance of the Code's section 365 provisions for rejection of an executory contract would have be

\footnotetext{
${ }^{222}$ In re Mirant Corp., 303 B.R. 319 (Bankr. N.D. Tex. 2003).

${ }^{223}$ In re Mirant Corp., 303 B.R. 304 (N.D. Tex. 2003).

${ }^{224}$ Official Comm. of Unsecured Creditors of Mirant Corp. v. Potomac Elec. Power Co. (In re Mirant Corp.), 378 F.3d 511, 524 (5th Cir. 2004).

${ }^{225} \mathrm{Id}$. at 523.

${ }^{226}$ Id. at 523 (citing In re Southmark Corp., 49 F.3d 1111, 1116 (5th Cir. 1995) (citing in turn In the Matter of Oxford Mgmt., Inc., 4 F. 3d 1329, 1334 (5th Cir. 1993) (quoting United States v. Sutton, 786 F. 2d 1305, 1308 (5th Cir. 1986)))).
} 
permissible under section $105(\mathrm{a}) .^{227}$ The problem was not with using section 105 (a) authority per se, but rather with the scope of its exercise.

The Bankruptcy Code assumes, as the Fifth Circuit noted that "a debtor is subject to ongoing agency regulation while in bankruptcy."228 Moreover, under section 362(b)(4), the FERC is usually exempt from the Bankruptcy Code's automatic stay provision. ${ }^{229}$ Even if an injunction of the FERC would further some other provision of the Code, it would seemingly contradict section $362(\mathrm{~b})(4)$, and certainly be contrary to the general policies expressed in the Code. Thus, there is a serious, if unmentioned, tension in the Fifth Circuit's Mirant decision. Even if section 105(a) were to be used in furtherance of the rejection provisions of section 365, it is not clear why this would give the bankruptcy court license to ignore or contradict other explicit provisions of the Code, unless section 105(a) were something closer to "a roving commission[] to do equity."

There is a reasonable textual solution to this tension, namely that section 362(b)(4) only exempts government regulatory agencies from the automatic stay, but still leaves open the possibility of an injunction on motion after the filing of a bankruptcy petition. In other words, the automatic stay does not prevent normal injunctions, even by a bankruptcy court. The Fifth Circuit, however, did not consider that possibility in the Mirant opinion. Instead, the Fifth Circuit adopted a common law-type solution. The Fifth Circuit declared that it would allow the use of section 105(a) powers to enjoin actors exempt under section 362(b)(4) from the automatic stay, but only under "exceptional circumstances."230 In other words, there is license to depart

\footnotetext{
${ }^{227}$ See Mirant, 378 F.3d.at 524.

${ }^{228} I d$. at 524.

229 See 11 U.S.C. $\$ 362(b)(4)$ (2000) (exempting from the automatic stay the "commencement or continuation of an action or proceeding by a governmental unit...to enforce such governmental unit's...police and regulatory power").

${ }^{230}$ La. PSC v. Mabey (In re Cajun Elec. Power Coop., Inc.), 185 F.3d 446, 457 n.18 (5th Cir. 1999) (C) 2006, Adam J. Levitin
} 
from the Code and even contradict explicit provisions, but this authority will be tested under the judge-made standard of "exceptional circumstances."

The cases that the Fifth Circuit relied on for authority in Mirant were of an entirely different ilk. The Fifth Circuit in Mirant cited In re Southmark Corp. ${ }^{231}$ for the proposition that section 105(a) does not constitute a "roving commission[] to do equity."232 Southmark in turn cites Chiasson v. J. Louis Matherne \& Assocs. (In re Oxford Management, Inc.) ${ }^{233}$ for this proposition, for which Oxford Management quotes United States v. Sutton ${ }^{234}$ as authority. These cases have also been relied on by courts outside the Fifth Circuit, ${ }^{235}$ including the Seventh Circuit in $K$-Mart ${ }^{236}$

Oxford Management and Sutton were clear cut cases of equity as pity, not equity to further reorganization or mitigate a harm. In Sutton, the Fifth Circuit affirmed the district court's reversal of bankruptcy court's section 105(a) authorization of monthly support payments from the estate to the wife and children of the formerly wealthy debtor in order to maintain them in a plantation-style house. ${ }^{237}$ At one point, these payments had been as high as \$10,000 a month. The bankruptcy court entered the support order on the theory that "the debtor had a continuing duty to support his spouse and children." 238 In doing so, the bankruptcy court confused the duty of the debtor as an individual with that of bankruptcy estate. Moreover, it went against the well-

(citing Corporacion de Servicios Medicos Hospitalarios de Fajardo v. Mora, 805 F.2d 440, 449 n.14 (1st Cir. 1986)).

${ }^{231} 49$ F.3d 1111, 1116 (5th Cir. 1995).

${ }^{232}$ In re Mirant Corp., 378 F.3d at 523.

${ }^{233} 4$ F.3d 1329, 1334 (5th Cir. 1993).

${ }^{234} 786$ F.2d 1305, 1308 (5th Cir. 1986).

${ }^{235}$ See, e.g., In re SPM Mfg. Corp., 984 F.2d 1305, 1311 (1st Cir. 1993); In re Chi., Milwaukee, 891 F.2d at 162 .

${ }^{236}$ Capital Factors v. K-Mart Corp., 359 F.3d at 871.

${ }^{237} 786$ F.2d 1305. See also Leal, supra note 160, at 491 n.6 (plantation-style house).

${ }^{238} I d$. at 1306. 
establish practice under the 1898 Act of not permitting such payments. ${ }^{239}$ While the wife and children of the debtor might be somewhat sympathetic figures, especially as they did not appear to have a hand in the debtor's undoing — criminal fraud in his oil business - they were not creditors (even though a ridiculous administrative expense claim was raised) and were arguably beyond the purview of the bankruptcy court's jurisdiction.

Curiously, Sutton is one of the few cases that refer to the legislative history of section 105(a). While Sutton notes that the House Report describes section 105(a) as akin to the All Writs Statute, ${ }^{240}$ the opinion omits the following sentence in the House Report, which stated that section 105(a) existed also "to cover any powers traditionally exercised by a bankruptcy court that are not encompassed by the All Writs Statute." ${ }^{241}$ If Sutton had considered this, it would have been in a quandary of determining what those "traditional powers" were, and as Sutton notes, under the 1898 Act the treatment of support claims from spouses and children changed over time. $^{242}$

Most notable about Sutton, however, is that the appeal presented a clear case inequitable use of equitable powers to provide excessive and lavish support for non-debtors. Although Sutton was not decided based on the level of support provided to the wife and children of the debtor, the excessive level of support undoubtedly swayed the court. With a different set of facts that would rebalance the equities, such as support payments to cover the medical bills of a terminally ill child or spouse, one wonders whether the Fifth Circuit would have reached the same conclusion. As such, Sutton is an exceptional case, and questionable authority for the general scope of bankruptcy courts' equitable powers.

\footnotetext{
${ }^{239} I d$. at $1306-07$.

${ }^{240} \mathrm{Id}$. at 1307.

${ }^{241}$ H.R. REP. NO. 95-595, at 316-317 (1977).

242786 F.2d at 1306-07.
} 
Oxford, ${ }^{243}$ a case frequently cited by the Fifth Circuit for the limitations on equity, also presents an exceptional scenario. In Oxford, the bankruptcy court ordered, under its section 105(a) powers, that the bankruptcy estate pay a pre-petition claim for a real estate commission outside of the plan. There was no critical vendor motion or claim that the payment was necessary for a reorganization. Rather, the bankruptcy judge (and the affirming district court judge) simply thought that the payment was necessary for unspecified equitable reasons.

While there may be an unreported factual pattern behind Oxford that explains the actions of the bankruptcy court, this is the sort of application of equity that smacks of the Chancellor's proverbial foot, ${ }^{244}$ a "what the judge ate for breakfast" jurisprudence. If equity is ever to be applied, it should be for specific ends beyond feeling kindly towards a particular party. The application of equity to facilitate a reorganization for the general aggregate benefit of the parties involved or to mitigate what could become an irreparable injury, as in Mabey, should be evaluated differently than "gee, I liked that creditor" cases. To that end, a clearer articulation of federal common law tests than "exceptional circumstances" is crucial. As courts feel their way through the problems of discretion, they often stumble into the creation of federal common law, but the results are clunky, in part because there is little awareness of the endeavor.

The pattern in the Fifth Circuit is typical: when dealing with easy cases of clear abuse of discretion, the circuit court waxed eloquent with overbroad dicta about the scope of bankruptcy equity, without pointing to any particular authority. Then, when tougher cases later arose, in

\footnotetext{
${ }^{243} 4$ F.3d 1329 (5th Cir. 1993).

${ }^{244}$ See John Selden, TABLE TALK 43 (Pollock ed., 1927) ("Equity is A Roguish thing, for Law wee have a measure known what to trust too. Equity is according to the conscience of him that is Chancellor, and as that is larger or narrower, soe is equity. Tis all one as if they should make the Standard for the measure wee call A foot, to be the Chancellors Foot; what an uncertain measure would this be; One Chancellor ha's a long foot another A short foot a third an indifferent foot; this the same thing in the Chancellors Conscience.").
} 
which non-Code practices were urged for a more meritorious use, the dicta from the earlier cases serves as a bar. Too often, it is dicta and not actual holdings, limited by their facts, that are remembered. Thus, it is likely that Judge Easterbrook's unfortunate Jovian wit in K-Mart, that “A 'doctrine of necessity' is just a fancy name for a power to depart from the Code," will be what lasts of the opinion, not his actual moderate holding that permits sufficiently reviewed and documented critical vendor orders.

\section{The Dangers of the Teleological Approach to Bankruptcy: Just For Feet}

The previous sections illustrate the problems that arise when courts apply catch-phrases and slogans from earlier decisions outside of the original unusual factual contexts in order to limit the exercise of bankruptcy equity. Different problems arise, however, when courts take a more generous view of bankruptcy equity.

In Just For Feet, for example, the District Court for the District of Delaware authorized the pre-plan payment of foreign and domestic trade vendors under the necessity of payments doctrine and section 105(a) because "paying certain pre-petition claims may be necessary to realize the goal of chapter 11-a successful reorganization." 245 Declaring that it was within "its equitable powers to authorize payment to vendors when such payment is critical to the reorganization," the district court interpreted section 105(a) to authorize actions taken to fulfill the policy goal, not just specific statutory provisions, of the Bankruptcy Code, even though the effect of its ruling was to deviate from the Code's distribution scheme. ${ }^{246}$ Just For Feet would

\footnotetext{
245242 B.R. 825-26 (D. Del. 1999) (emphasis added).

${ }^{246}$ Id. Allowing pre-plan payments in full to certain critical vendors functionally subordinates other unsecured creditors. See supra note 181. Section 510(c) of the Code authorizes subordination of claims, 11 U.S.C. 510(c) (2000), but instructs that this is to be done in accordance with principles of equity, and equitable subordination usually requires that the subordinated party have unclean hands. See, e.g., $B \& W$ Enters., 713 F.2d at 537-38 ("the subordination of a creditor's claim normally requires a showing that the creditor 'has acted inequitably in the course of his relationship with the debtor and that those actions have
} 
imply that unless there is a literal and unavoidable contradiction between the action taken under the equitable powers and a controlling precedent or statute, there is no limit on the equitable powers as long as they further reorganization. This is the danger of the teleological approach to bankruptcy that places successful reorganization over everything else. The rights of nonconsenting creditors get trampled for the sake of the reorganization.

Courts' desire to cabin off equitable discretion has led to a heavy emphasis on finding some sort of statutory authorization for non-Code practices in bankruptcy equity. This, in turn, has led to an inappropriate reliance on section 105(a) as a framework for analyzing non-Code practices and produced numerous decisions that are decidedly at odds with the general tenor of equity in the sense of substantial justice, as expressed in Pepper v. Litton. Even in cases where the equities were clear-cut, such as Mabey, the courts felt that without explicit statutory authorization, they were unable to rule with the equities. On the other hand, as Just for Feet shows, some sort of limiting principle on the application of bankruptcy equity is necessary.

\section{HISTORICAL LIMITATIONS ON BANKRUPTCY EQUITY}

\section{A. Historical Equity PoWers: Grupo Mexicano de Desarkollo, S.A. V. AllianCE Bond FUND, INC.}

Historical practice is the other method courts have used to constrain equity. The clearest example of this method of limitation is Grupo Mexicano de Desarrollo, S. A. v. Alliance Bond Fund, Inc. ${ }^{247}$ Grupo Mexicano was not a bankruptcy case; it was an insolvency case dealing with the ability of federal courts to craft creative remedies using their equity powers. Grupo

harmed the debtor or his other creditors in some way."').

The Just For Feet court's lack of hesitation in allowing pre-plan payments to critical vendors may have been because the debtor appeared to be balance-sheet solvent and merely suffering from liquidity problems, 242 B.R. at 823, a situation not unlike that in Chicago, Milwaukee. If this were the case, then a pre-plan payment would not change the distribution scheme because all creditors could be paid in full, although they would have incurred a risk in the interim.

247527 U.S. 308 (1999). 
Mexicano, however, amply illustrates both the prudential concerns underlying courts' discomfort with equitable discretion and the problems of using historical practice as a limiting device.

One of Grupo Mexicano's creditors feared that Grupo Mexicano was insolvent and preferring its Mexican creditors in its asset allocation in order to frustrate its American creditors' efforts to enforce any possible judgment for them. The creditor requested a preliminary injunction restraining Grupo Mexicano from transferring its assets. The district court granted the preliminary asset freeze injunction.

On appeal, the Supreme Court held that the district court did not have the authority to issue such an injunction. The Court noted that "[w]e do not question the proposition that equity is flexible; but in the federal system, at least, that flexibility is confined within the broad boundaries of traditional equitable relief."248 Accordingly, the Supreme Court ruled that federal courts have the equity jurisdiction that was exercised by the English Court of Chancery at the time the Constitution was adopted and the Judiciary Act of 1789 was enacted. "[T]he equitable powers conferred by the Judiciary Act of 1789 did not include the power to create remedies previously unknown to equity jurisprudence."249 Without specific statutory authorization the judicial power is limited to its original meaning. The injunction requested by the creditor was a so-called "Mareva" injunction, which was first deployed by the English Chancery in $1975,{ }^{250}$ and was a "dramatic departure from prior practice." 251

Citing Justice Joseph Story's Commentaries on Equity Jurisprudence, the Court rejected the idea that equitable remedies could be any remedy that appealed to "the grand aims of equity," or which was part of "a general power to grant relief wherever legal remedies are not "practical

\footnotetext{
248527 U.S. at 322.

${ }^{249} \mathrm{Id}$. at 332.

${ }^{250} \mathrm{Id}$. at 328 n.9.

${ }^{251}$ Id. at 328.
} 
and efficient,' unless there is a statute to the contrary."252 Such a power, according to Justice Scalia's opinion, would be inconsistent with a "government of laws, not of men." 253 Unchecked judicial discretion would make equity vary with the length of the Chancellor's proverbial foot. ${ }^{254}$ In the bankruptcy context, such arbitrary justice would lead to incongruous decisions that are particular incompatible with the uniformity sought by any Code-based regime. It would also create tremendous uncertainty for creditors and debtors.

Underlying the Court's concern about unbridled equity powers is a concern about separation of powers. If there were no limits on federal courts' equity powers other than efficiency and practicality, it would be the courts, and not Congress, that would determine not only what remedies exist for the vindication of rights, but also, by extension, what rights exist, for "where there is a legal right, there is also a legal remedy." granting of a Mareva injunction would have acknowledged a right to such an injunction. As the Supreme Court recognized, it cannot be the province of the court to create such rights; the Constitutional role of the courts is not to legislate. Legislation by politically unaccountable actors such as unelected Article III judges with life tenure and salary protection or even of bankruptcy judges, appointed by the Circuit Courts for terms, runs contrary to the entire notion of separation of powers.

Although the Supreme Court used the language of separation of powers, one can also sense a general judicial nervousness about "doing justice" instead of "doing law." The Court simply did not know what to do with "a roving commission to do equity," particularly in a case

\footnotetext{
${ }^{252} I d$. at 321 . We should be chary of taking Story's treatise as a normative statement-treatises are as frequently normative as positive-but a full analysis of Story's approach to equity jurisprudence is beyond the scope of this article.

${ }^{253}$ Id. (quoting Marbury, 5 U.S. at 163).

${ }^{254}$ See supra note 244.

${ }^{255}$ Marbury, 5 U.S. at 163.
} 
involving a struggle between various sophisticated creditors, in which one's moral compass provides little guidance. This is apparent from the odd manner in which the Court tried to limit equitable discretion. The Court's originalist reading of Article III equity power evidences surprising judicial modesty for a Court that would surely not limit its power to hear only forms of actions available in 1789. It also ignores the evolving nature of equity up to 1789 , not to mention its evolution in British courts since 1789 (such as the development of the Mareva injunction). Grupo Mexicano is an arbitrary amputation of a living judicial tradition.

However questionable the 1789 English Chancery standard is, it should not be surprising, for it is hard to think of another bright line rule for sorting exercises of equitable discretion that would not be at least as strange. The originalist decision in Grupo Mexicano is strong evidence of courts' general discomfort with discretion and their desire to channel and guide the exercise of such discretion. Statutory (or Constitutional) language is the preferred means of limiting discretion, but when these tools are not available, discretion must still be curtailed, even if it involves creating judicial glosses on text or even federal common lawmaking, an act which invokes the very separation of powers problem that Grupo was concerned with-judicial lawmaking. Judicial lawmaking, then, is chiefly a concern when it is an exercise of judicial discretion rather than effecting a channeling thereof.

Grupo Mexicano raises several questions from the perspective of bankruptcy jurisdiction. First, does Grupo Mexicano apply to bankruptcy courts? If so, how much of a limitation would this put on bankruptcy equity powers? Does Grupo Mexicano conflict with the pre-Code practices doctrine?

The Supreme Court's 1935 holding in Continental Illinois National Bank \& Trust Co. v. Chicago, Rock Island, and Pacific Railway Co. counsels against an application of Grupo 
Mexicano to bankruptcy. In Continental Illinois, the Supreme Court noted that "the power of Congress under the bankruptcy clause is not to be limited by the English or Colonial law in force when the Constitution was adopted." 256 But does this mean that Grupo Mexicano only binds equity powers of federal courts when not in bankruptcy? It would be an unusual situation if federal courts' equity powers in general were far more constricted than their equity powers in bankruptcy; surely Congress did not conceive of such a differentiation when granting bankruptcy courts equity powers - it intended to grant the same equity powers as otherwise existed. The language of 28 U.S.C. $\S 1481$, for example, states that "a bankruptcy court shall have the powers of a court of equity, law, and admiralty, but may not enjoin another court or punish criminal contempt not committed in the presence of the judge of the court or warranting a punishment of imprisonment." 257 Thus, the grant of equity powers to bankruptcy courts was of the general equity powers of federal courts. Congress could not grant more than exists; indeed, 28 U.S.C. $\S$ 1481 grants more limited equity powers than federal courts generally have, as it excludes criminal contempt powers and the injunction of other courts' actions.

Assuming that Continental Illinois is not a bar to the application of Grupo Mexicano to bankruptcy, Grupo Mexicano appears, then, initially, to bind bankruptcy courts. Grupo Mexicano refers to "federal courts," 258 not just district courts. Are bankruptcy courts "federal courts" in the sense of the Grupo Mexicano opinion? That is, does Grupo Mexicano apply only

\footnotetext{
${ }^{256}$ Cont'l Ill., 294 U.S. at 669-70 (internal citations omitted).

25728 U.S.C. $§ 1481$ (1982) (possibly repealed in 1984). The House Report on the Bankruptcy Code noted that section 1481 "gives the bankruptcy court the powers of a court of equity, law, and admiralty. It is the concomitant of the bankruptcy courts increased jurisdiction, and is necessary to enable the bankruptcy court to exercise that jurisdiction and its powers under the bankruptcy code. It is in addition to any power granted under 28 U.S.C. 1651 (the All Writs Statute) or under section 105 of the bankruptcy code." H.R. REP. No. 595; 95th Cong., 1st Sess; HR 8200 (Sept. 8, 1977).

${ }^{258} 527$ U.S. at 319 ("'the equity jurisdiction of the federal courts is the jurisdiction in equity exercised by the High Court of Chancery in England at the time of the adoption of the Constitution and the enactment of the original Judiciary Act, 1789 (1 Stat. 73.)"') (quoting A. Dobie, HANDBOOK OF FEDERAL JURISDICTION AND PROCEDURE 660 (1928)).
} 
to Article III courts, or to all federal courts?

There is nothing in Grupo Mexicano that indicates a limitation to Article III courts, but this is not an issue directly addressed by the opinion. By its very nature, however, the issue that arose in Grupo Mexicano could not have arisen in bankruptcy. As the Court itself noted,

The law of fraudulent conveyances and bankruptcy was developed to prevent such conduct [as Grupo Mexicano's]; an equitable power to restrict a debtor's use of his unencumbered property before judgment was not. ${ }^{259}$

Upon filing for bankruptcy, the assets of the debtor become part of a court-supervised estate; no assets can flow out of the estate without the court's approval. Moreover, the estate can recover assets transferred by the debtor before bankruptcy. ${ }^{260}$ The result, as Judith Resnik has noted, is that "in light of Grupo Mexicano, bankruptcy judges may have more power to freeze assets than do life-tenured judges, ${ }^{261}$ since asset transfers in bankruptcy require court approval, whereas district judges cannot freeze assets pending monetary relief. ${ }^{262}$

The greater power of bankruptcy courts to freeze assets than an Article III court does not say that the equity powers of a bankruptcy court are greater than that of an Article III court. The bankruptcy asset freeze is statutory, ${ }^{263}$ so it does not derive from bankruptcy courts' equitable powers, even if it can only be enforced via injunction. Indeed, because bankruptcy courts hear their cases on reference from the district court, ${ }^{264}$ a district court that did not refer a bankruptcy case would administer the same statutory asset freeze. The equity powers (as opposed to statutory powers) of a bankruptcy court cannot be greater than those of the district court, as the

\footnotetext{
259527 U.S. at 319.

${ }^{260}$ See 11 U.S.C. $§ 547$ (2000) (voidable preferences); § 548 (2000) (fraudulent transfers); Uniform Fraudulent Transfer Act, $\S \S 4-5$.

${ }^{261}$ Judith Resnik, Constricting Remedies: The Rehnquist Judiciary, Congress, and Federal Power, 78 IND. L.J. 223, 266 (2003).

${ }^{262}$ See In re Dow Corning, 280 F.3d 648, 657-58 (6th Cir. 2002).

26311 U.S.C. $\S 363$ (2000) (use of estate property); § 541 (2000) (property of the estate defined).

${ }^{264} 28$ U.S.C. $\S 157$ (2000).
}

(C) 2006, Adam J. Levitin 
bankruptcy court is a unit of the district court. Thus, Grupo Mexicano would define at least an outer boundary to the equity powers of bankruptcy courts.

On the other hand, bankruptcy courts exist as units of the district courts by virtue of statute, not the Constitution. Grupo Mexicano is a Constitutional holding addressing the powers inherent in Article III, clause 2. Since the authority of bankruptcy courts derives Constitutionally from Congress's Bankruptcy Power under Article I, Clause $8,{ }^{265}$ Grupo Mexicano may not affect bankruptcy courts. Indeed, the powers of bankruptcy courts might, in some areas, be greater than that of Article III courts, as they are Constitutionally limited only by Bankruptcy Power and generally applicable provisions such as the requirement of Due Process. ${ }^{266}$

Conceivably, then, bankruptcy courts' equity powers could exceed those of the district courts. Yet, the Supreme Court has, in the context of the Appointments clause, noted that Article I courts exercise the "judicial power" referred to in Article III, clause $1 .^{267}$ This presents a strong indication that Article III-based holdings will apply to non-Article III courts when they exercise the "judicial power", of which equity powers are unquestionably a part.

\section{Grupo Mexicano in Bankruptcy}

Assuming Grupo Mexicano limits the equity powers of bankruptcy courts, how has this affected actual bankruptcy practices? Lower courts have generally managed to make Grupo Mexicano inapplicable in two ways. Some lower courts have claimed a statutory, non-equitable authorization for the practice in question. Others claim that Grupo Mexicano does not apply to bankruptcy proceedings. ${ }^{268}$ Still other lower courts have claimed that the non-Code practice has

\footnotetext{
${ }^{265}$ U.S. CONST. art. I, § 8, cl. 4.

${ }^{266}$ See John T. Cross, Congressional Power to Extend Federal Jurisdiction to Disputes Outside Article III: A Critical Analysis from the Perspective of Bankruptcy, 87 Nw. U. L. REV. 1188, 1199 (1993).

${ }^{267}$ Freytag v. Comm'r of Internal Revenue, 501 U.S. 868, 889 (1991).

${ }^{268}$ In re Owens Corning, 419 F.3d at 209 n.14.
}

(C) 2006, Adam J. Levitin 
been ratified as a matter of federal common law before Grupo Mexicano was decided, that is, that the relief in question is "traditional equitable relief" even if its pedigree does not extend to the English Chancery in 1789.

In In re Stone \& Webster, the both methods were at work. In Stone \& Webster, a reorganization plan was presented that provided for the substantive consolidation of the debtor and some seventy-two debtor subsidiaries into one estate. ${ }^{269}$ This would obviously affect the payout that various creditors could receive. Under the unconsolidated plan, the creditors of the parent debtor would receive a $100 \%$ recovery and its shareholders $\$ 3 /$ share, while the creditors of a subsidiary would get only $7 \varnothing$ on the dollar at most. ${ }^{270}$ "With substantive consolidation, creditors of all debtors [would] receive significant recovery from aggregated estates," but the parent's creditors would not get 100 cents on the dollar. ${ }^{271}$

The parent debtor's equity holders' committee argued against the substantive consolidation and claimed that it was beyond the scope of the court's equity powers in light of Grupo Mexicano. $^{272}$ The bankruptcy court reviewed the long history of substantive consolidation and noted with particular relish a 1941 case, Sampsell v. Imperial Paper \& Color Corp. ${ }^{273}$ in which the Supreme Court itself upheld substantive consolidation. ${ }^{274}$ The bankruptcy court ultimately granted the substantive consolidation based on statutory authorization under section 1123 of the Code ${ }^{275}$ instead of section 105 (a) powers. Nonetheless, the bankruptcy court strongly implied that it believed that substantive consolidation would survive Grupo Mexicano, absent section

\footnotetext{
${ }^{269}$ In re Stone \& Webster, 286 B.R. 532 (Bankr. D. Del., 2002).

${ }^{270} I d$. at 536.

${ }^{271} I d$.

${ }^{272} I d$.

273313 U.S. 215, 219 (1941).

274286 B.R at 538-39.

27511 U.S.C. $\$ 1123$ (2000).
} 
1123, based on its historic status. ${ }^{276}$ Likewise, in Owens-Corning, the Third Circuit determined that Grupo Mexicano was not a bar to substantive consolidation, even though it ultimately decided against a deemed substantive consolidation in regard only to some creditors. ${ }^{277}$

The argument that Grupo Mexicano does not apply to non-Code practices of sufficient historical pedigree was made explicit by the Bankruptcy Court for the Middle District of Tennessee in granting a substantive consolidation motion in In re American Homepatient, Inc. Although the American Homepatient court was aware of the Stone \& Webster decision, ${ }^{278}$ which avoided ruling on the issue, the American Homepatient court ruled that Grupo Mexicano did not bar substantive consolidation under equity powers and granted the consolidation motion. ${ }^{279}$ The court noted the long pedigree of substantive consolidation and that the practice had been repeatedly ratified by the Supreme Court under the Act. ${ }^{280}$ In the eyes of the American Homepatient court, this made substantive consolidation acceptable under Grupo Mexicano, even though it never addressed whether such a remedy was possible in 1789 or if Grupo Mexicano impliedly repudiated earlier Supreme Court decisions. ${ }^{281}$ It was good enough for the American Homepatient court that the practice had existed, with the Supreme Court's blessing, under the 1898 Act and had not been repudiated by the Code.

Class Five Nev. Claimants v. Dow Corning Corp. (In re Dow Corning Corp. $)^{282}$ presents the most amazing twist on Grupo Mexicano's application in bankruptcy. In Dow Corning, the

\footnotetext{
276286 B.R. at 537.

${ }^{277}$ In re Owens Corning, 419 F.3d at 209 n.14.

${ }^{278}$ In re Am. Homepatient, Inc., 298 B.R. 152, 165 (Bankr. M.D. Tenn. 2003).

${ }^{279} I d$. at 166.

${ }^{280} I d$. at 165 .

281 Similar reasoning, albeit less explicit appears in Official Comm. of Asbestos Claimants v. G-I Holdings, Inc. (In re G-I Holdings Inc.), 2001 Bankr. LEXIS 2029, at *19-*20 (Bankr. D.N.J. 2001) (finding authority to consolidate debtors, but declining to do so).

282280 F.3d 648 (6th Cir. 2002).
} 
bankruptcy court held that non-debtor releases were authorized by section $1123(\mathrm{~b})(6),{ }^{283}$ but refused to approve the releases because it believed that they were precluded by Grupo Mexicano. ${ }^{284}$ The district court reversed on the basis that the statutory authorization trumped the Constitutional limitation on equitable, but not statutory powers. ${ }^{285}$

The Sixth Circuit upheld the district court on similar reasoning, but cited section 105(a) as the grant of statutory power to carry out non-debtor releases through injunctions. ${ }^{286}$ The Sixth Circuit concluded that "due to this statutory grant of power [in section 105(a)], the bankruptcy court is not confined to traditional equity jurisprudence and therefore, the bankruptcy court's Grupo Mexicano analysis was misplaced."287 The underlying assumption of the Sixth Circuit's opinion was that Grupo Mexicano applies to the equity powers of the bankruptcy courts. ${ }^{288}$ The only reason that Grupo Mexicano did not bar the non-debtor releases is that they were not an exercise of equitable powers, but rather an exercise of section 105(a) powers, which the Sixth Circuit correctly read as a grant of statutory powers and not a statutory grant of equitable powers.

Grupo Mexicano may limit some non-Code practices. To the extent that a court finds statutory authorization for those practices under section 105(a), however, it can claim that Grupo Mexicano is inapplicable because it governs only the exercise of equity powers that exist under Article III, not statutory grants of equity powers. Even if Grupo Mexicano's technical limitations can be avoided in the bankruptcy context, though, it does not follow that Grupo Mexicano's underlying separation of powers concern is assuaged, a problem considered in greater detail below.

${ }^{283} 11$ U.S.C. $§ 1123$ (b)(6) (2000) ("Subject to subsection (a) of this section, a plan may...(6) include any other appropriate provision not inconsistent with the applicable provisions of this title.").

${ }^{284}$ See In re Dow Corning Corp., 244 B.R. 721, 744 (Bankr. E.D. Mich. 1999).

${ }^{285}$ See In re Dow Corning Corp., 255 B.R. 445, 480 (E.D. Mich. 2000).

${ }^{286} \mathrm{See} 280$ F.3d at $657-658$.

${ }^{287} I d$.

${ }^{288}$ Cf. In re Owens Corning, 419 F.3d at 209 n.14.

(C) 2006, Adam J. Levitin 


\section{B. THE PRE-Code PRACTICES Doctrine}

\section{Section 105(a) as a Source for the Pre-Code Practices Doctrine?}

Even though Grupo Mexicano may not apply to bankruptcy courts, historical practice serves as a limitation on (or justification for) equitable powers in bankruptcy through the preCode practices doctrine. The pre-Code practices doctrine is the statutory interpretation principle, repeatedly enunciated by the Supreme Court, ${ }^{289}$ that pre-Code practices continue to be valid, unless Congress evinced clear intent to depart from them under the Code. Although the preCode practices doctrine has come to us in Supreme Court decisions, the earliest hint at such a doctrine is in the legislative history of section 105(a).

Arguably, although the plain language of section 105(a) does not authorize equity powers, it is a device that incorporates bankruptcy courts' historical equity powers into the Code. Such a reading is not apparent from the text of section 105(a), but the House Committee Report noted that section 105(a) was meant to "cover any powers traditionally exercised by a bankruptcy court that are not encompassed by the All Writs Statute. ${ }^{290}$ Thus, according to the House Report, section 105(a) goes beyond the All Writs Statute and incorporates historical bankruptcy court powers into the Code.

If the legislative history is given credence, section 105(a) merely confirms the pre-Code powers of a bankruptcy court. These pre-Code powers cannot include general equity powers, however. Equity powers were authorized as a matter of statute under the 1898 Act. Whatever powers section 105(a) incorporates, it cannot include those that were statutorily authorized under the 1898 Act, or else section 105(a) would reincorporate the entire 1898 Act. Given that the 1978 Code replaced the 1898 Act, such a broad reading of the legislative history of section

${ }^{289}$ See discussion accompanying notes 293-335 infra.

${ }^{290}$ H.R. REP. NO. 95-595, at 316-317 (1977).

(C) 2006, Adam J. Levitin 
105 (a) is not tenable. What, then, was the legislative history referring to? Clearly to some unenumerated powers of bankruptcy courts.

Unfortunately, only a handful of the published opinions that consider the scope of section 105(a) reference the legislative history. None have seriously considered what "powers traditionally exercised by a bankruptcy court" means. Incorporation of historical practice is extremely problematic because bankruptcy practice has not been static in the United States for the last two centuries nor has it been uniform. Variation between districts and referees were major complaints under the 1898 Act. ${ }^{291}$ At the very least, one would like to know to how widespread and well-established "traditional powers" must be, whether these powers can be expanded by analogy, whether they include powers from proceedings similar to bankruptcy, such as equity receiverships, ${ }^{292}$ and, most importantly, whether a bankruptcy court's traditional powers included general equitable powers or only specific, limited equitable powers.

Although it is unclear precisely what powers section 105(a) was referring to, it seems to state that section 105(a) incorporates the pre-1978 federal common law of bankruptcy as developed under the 1898 Act. Obviously, this is tempered by any provision in the 1978 Code explicitly disavowing such pre-1978 federal common law. In other words, this is essentially a statement of the pre-Code practices doctrine.

\section{Development of the Pre-Code Practices Doctrine}

The Supreme Court first addressed the relation between equity and pre-Code practices in a series of cases from 1986 to 1998: Midlantic National Bank v. New Jersey Department of Environmental Protection, ${ }^{293}$ Kelly v. Robinson, ${ }^{294}$ United Savings Ass'n. of Texas v. Timbers of

\footnotetext{
${ }^{291}$ Wiensch, supra note 166 , at 1831.

${ }^{292}$ See supra note 212.

${ }^{293} 474$ U.S. 494 (1986).
}

(C) 2006, Adam J. Levitin 
Inwood Forest Assocs., Ltd., ${ }^{295}$ Ahlers, ${ }^{296}$ United States v. Ron Pair Enterprises, Inc., ${ }^{297}$ Pennsylvania Department of Public Welfare v. Davenport, ${ }^{298}$ and Cohen v. de la Cruz. ${ }^{299}$ The majorities in these cases shifted, and the Court usually addressed the role of pre-Code practices in dicta, but, taken as a whole, these cases form a clear jurisprudence on the role of pre-Code practices in bankruptcy. These cases also point to the existence of a federal common law of bankruptcy before the 1978 Code.

The Court first addressed the role of pre-Code practices in a pair of 1986 opinions, Midlantic National Bank v. New Jersey Department of Environmental Protection and Kelly v. Robinson. In these decisions, the Court emphasized that the Code was written against the background of bankruptcy practice as developed under the 1898 Act, which must inform any reading of the Code. In Midlantic, the Court refused to hold that the Bankruptcy Code abrogated exceptions created by the courts in construing the Bankruptcy Act. In other words, while specific Code sections supplant pre-Code practices, there is no general presumption that preCode practices have been displaced by the Code. The Court also acknowledged the special place of pre-1978 federal common law in bankruptcy:

The normal rule of statutory construction is that if Congress intends for legislation to change the interpretation of a judicially created concept, it makes that intent specific. The Court has followed this rule with particular care in construing the scope of bankruptcy codifications. ${ }^{300}$

Thus, the Code does not abrogate what we might characterize as the pre-1978 federal common law of bankruptcy as a whole.

\footnotetext{
294479 U.S. 36 (1986).

295484 U.S. 365 (1988).

296485 U.S. 197 (1988).

297489 U.S. 235 (1989).

298495 U.S. 552 (1990).

299523 U.S. 213 (1998).

300474 U.S. at 501 (emphasis added).
}

(C) 2006, Adam J. Levitin 
On these lines, the Court in Kelly v. Robinson ${ }^{301}$ specifically looked to the practice of courts under the Act, even though the practice was itself a departure from the text of the Act. The debtor in Kelly had been convicted of welfare fraud but given a suspended sentence conditioned on meeting the terms of her probation, which included making restitution payments. ${ }^{302}$ The debtor then filed for bankruptcy, listed her restitution obligations as a debt, and received a discharge. ${ }^{303}$ When the debtor ceased making her restitution payments, the state probation authority informed her than it considered the restitution obligation nondischargeable. ${ }^{304}$ The debtor then filed for a declaratory judgment from the bankruptcy court, which held the debt to be dischargeable under section 523(a)(7) of the Code, 11 U.S.C. $\S$ 523(a)(7), which prohibits the discharge of any debt "to the extent such debt is for a fine, penalty, or forfeiture payable to and for the benefit of a governmental unit, and is not compensation for actual pecuniary loss.",305 The debtor argued that the restitution payments were for actual pecuniary loss and thus dischargeable and appealed.

The Supreme Court held that the restitution obligation was non-dischargeable because the statute under which the restitution order was made did not require restitution to correlate with the actual loss suffered. ${ }^{306}$ The legislative history of the Bankruptcy Code also swayed the Court in its interpretation that section 523(a)(7) was not meant to allow the discharge of criminal restitution orders. The language of the Bankruptcy Act of 1898 had allowed for (but did not require) the discharge of criminal penalties. ${ }^{307}$ Most courts, however, had refused to discharge

\footnotetext{
301479 U.S. 36 (1986).

${ }^{302} I d$. at 38-39.

${ }^{303} I d$.

${ }^{304} I d$. at 39-40.

${ }^{305} \mathrm{Id}$. at 40-41.

${ }^{306} \mathrm{Id}$. at 52-53.

307 See The Bankruptcy Act of 1898, Ch. 541, §§ 17, 57, 63, 30 Stat. 544.
}

(C) 2006, Adam J. Levitin 
criminal penalties. $^{308}$ Thus:

Congress enacted the Code in 1978 against the background of an established judicial exception to discharge for criminal sentences, including restitution orders, an exception created in the face of a statute drafted with considerable care and specificity. $^{309}$

Kelly, like Midlantic, teaches that a reading of the provisions of the Bankruptcy Code must be informed by the pre-1978 federal common law of bankruptcy-non-statutory pre-Code practices.

In United States v. Ron Pair Enterprises, Inc. ${ }^{310}$ the Court took a very narrow reading of its decisions three years earlier in Midlantic and Kelly. The government had secured a tax lien on debtor and objected to a reorganization plan that did not grant it post-petition interest on its lien, up to the value of the collateral. ${ }^{311}$ The debtor urged that judgment and statutory liens be treated differently than consensual security interests. ${ }^{312}$ The debtor claimed that pre-Code practice distinguished between consensual and non-consensual liens and, citing Midlantic and Kelly, argued that absent explicit repudiation in the Bankruptcy Code, such practices should be assumed to continue. ${ }^{313}$

The Court rejected the debtor's argument and distinguished Midlantic and Kelly in ruling for the Government. The Court noted that its Midlantic decision was not dependent upon preCode practice, which merely provided "interpretive assistance." 314 Similarly, pre-Code practice was but an interpretive aid in Kelly, as it "reflected policy considerations of great longevity and importance." 315 The Court emphasized that "in determining that Congress had not intended to

\footnotetext{
${ }^{308} 479$ U.S. at $44-46$.

${ }^{309} \mathrm{Id}$. at 46 (emphasis added).

${ }^{310} 489$ U.S. 235 (1989).

${ }^{311} I d$. at 237.

${ }^{312} I d$. at 243.

${ }^{313} I d$.

${ }^{314} \mathrm{Id}$. at $243-244$.

${ }^{315} \mathrm{Id}$. at 245.
} 
depart from pre-Code practice...we did not rely on a pale presumption to that effect." ${ }^{\text {"16 }}$ Thus, "in an appropriate case, a court must determine whether Congress has expressed an intent to change the interpretation of a judicially created concept in enacting the Code." ${ }^{317}$

Such appropriate cases, however, do not include those where the statutory language of the Bankruptcy Code is clear, and its natural interpretation does not conflict with any significant state or federal interest, such as criminal justice or environmental protection, or with other parts of the Code. ${ }^{318}$ In short, when interpreting unambiguous statutory language that does not conflict with other law, there is no reason to turn to pre-Code practices. Moreover, the Court noted, preCode practice must be widespread and consistent to be considered. ${ }^{319}$ If a practice only existed in a few cases, Congress cannot be assumed to be cognizant of it. ${ }^{320}$

Four Justices dissented and argued that the statutory language in question was far from unambiguous $^{321}$ and that the Court took too narrow a view of Midlantic and Kelly. ${ }^{322}$ Instead, the dissent claimed that, "The rule of Midlantic is that bankruptcy statutes will not be deemed to have changed pre-Code law unless there is some indication that Congress thought it was effecting such a change." ${ }^{323}$ The dissent also noted that in the previous term, the Court had declared, "[I]t is most improbable that [a change in the existing bankruptcy rules] would have been made without even any mention in the legislative history." ${ }^{324}$ In Ron Pair the Court backed

\footnotetext{
${ }^{316} I d$. at $244-245$.

${ }^{317} I d$. at 245.

${ }^{318} I d$.

${ }^{319} I d$. at 246.

${ }^{320}$ Id. Cf. Bildisco, 465 U.S. at 525 (noting that there cannot be a presumption that Congress adopted any particular pre-Code practice if that practice was not consistent and widespread).

${ }^{321}$ Ron Pair Enters., 489 U.S. at 249.

${ }^{322} I d$.

${ }^{323} I d$. at 252.

${ }^{324}$ Id. at 254 (quoting Timbers of Inwood Forest, 484 U.S. at 380 (unanimously affirming that "adequate protection" under 11 U.S.C. $§ 362(d)(1)$ (1982) does not entitle an undersecured creditor to interest on its collateral during the automatic stay)).
}

(C) 2006, Adam J. Levitin 
away from the broad statement about the role of pre-Code practices in interpreting the Code that it had articulated in Midlantic and Kelly.

Two years later, however, in Pennsylvania Dept. of Public Welfare v. Davenport, ${ }^{325}$ the Court appeared to reaffirm the broad reading of Midlantic and Kelly. Davenport presented the same issue as Kelly, the dischargability of criminal restitution orders, but in a Chapter 13 context. In Kelly, a Chapter 7 case, the Court held the restitution order to be non-dischargeable. ${ }^{326}$ In Davenport, however, the Court ruled, based on different statutory language, that restitution orders are dischargeable in Chapter 13. The 7-2 majority emphasized, though, in a point that the dissent echoed for its own argument: ${ }^{327}$

Our refusal to carve out a broad judicial exception to discharge for restitution orders does not signal a retreat from the principles applied in Kelly. We will not read the Bankruptcy Code to erode past bankruptcy practice absent a clear indication that Congress intended such a departure. ${ }^{328}$

The crucial factor for the Court was the unambiguous statutory language: "Where, as here, congressional intent is clear, our sole function is to enforce the statute according to its terms., ${ }^{329}$

\section{The Current State of the Pre-Code Practices Doctrine}

The most recent Supreme Court statement on the pre-Code practices comes from Cohen v. de la Cruz, ${ }^{330}$ a civil parallel to Kelly. In Cohen, the Court held that section 523(a)(2)(A) barred the discharge of liability arising from the debtor's fraud, including punitive damages. The statutory language in question excepted from discharge "any debt...for money, property, services, or...credit, to the extent obtained by...false pretenses, false representation, or actual

\footnotetext{
325495 U.S. 552 (1990).

${ }^{326}$ See supra note 306.

${ }^{327} 495$ U.S. at 565.

${ }^{328} I d$. at 563 .

${ }^{329} \mathrm{Id}$. at 564 .

${ }^{330} 523$ U.S. 213 (1998).
} 
fraud", ${ }^{331}$ and thus could be read not to cover punitive damages, depending on whether the emphasis was on "any debt" or "debt...for." The unanimous Court noted that under the Bankruptcy Act of 1898, all liabilities arising from fraud were non-dischargeable, not just the portion of liability that was restitutive. ${ }^{332}$ The Court quoted Davenport ${ }^{333}$ to the extent that the Bankruptcy Code cannot be read, "to erode past bankruptcy practice absent a clear indication that Congress intended such a departure." 334 This factor, along with the statutory language, the meaning of parallel statutory provisions, and the general policy against allowing bankruptcy to be used to shed liability for fraudulent behavior all supported the decision. ${ }^{335}$ While the decision in Cohen v. de la Cruz did not rest solely on resort to pre-Code practices, it shows the continuing importance of pre-Code practice in elucidating the statutory language of the Code.

The Court's well-established methodology for bankruptcy cases is this: first consider the applicable statutory language. If it is clear, then apply that language. If the language is ambiguous, however, then there can be recourse to pre-Code practices as an interpretive aid similar to legislative history. This methodology puts tremendous pressure on the Court's determination of the clarity of the statutory language, much as the Court's parallel Chevron methodology ${ }^{336}$ in Administrative Procedure Act cases does. ${ }^{337}$ There is an unfortunate circularity to this methodology; the clarity of statutory language is sometimes only apparent in light of an examination of non-textual sources, such as pre-Code practices and legislative history.

\section{Problems with the Pre-Code Practices Doctrine}

\footnotetext{
${ }^{331} 11$ U.S.C. 523(a)(2)(A) (2000).

${ }^{332}$ See 523 U.S. at 221.

333495 U.S. at 563.

${ }^{334} 523$ U.S. at 221 (internal quotation marks and citation omitted).

${ }^{335} \mathrm{Id}$. at 222.

${ }^{336}$ Chevron, 467 U.S. 837.

${ }^{337}$ Alan Schwartz, Constitutional Law and the Supreme Court: the New Textualism and the Rule of Law Subtext in the Supreme Court's Bankruptcy Jurisprudence, 45 N.Y.L. SCH. L. REV. 149, 187 (2001).
} 
The pre-Code practices doctrine is problematic. First, it places an arbitrary limit on the development of the federal common law of bankruptcy. By authorizing pre-Code non-Code practices, there is an implicit exclusion of post-Code non-Code practices. This distinction makes little sense. Bankruptcy law existed as a matter of statute both before and after 1978. The Court has recognized the existence of federal common law of bankruptcy from before 1978. Why should there not be post-1978 federal common law? While the 1978 Code might affect pre-Code federal common law, there is no reason to think that it precludes a continuing development of federal common law of bankruptcy

Indeed, federal common law is arguably more important than ever for the successful operation of the bankruptcy system. Reorganization techniques have only become more complex under the Code. Shouldn't bankruptcy courts have the flexibility to adapt to these techniques? Most other areas of federal law have agencies with rule-making authority that give those areas of law the flexibility to adapt to new developments via interstitial lawmaking. Bankruptcy is alone among major areas of federal law in lacking an administrative agency with rule-making power. Why shouldn't bankruptcy judges, who, like agencies, are Article I entities with particular technical expertise, have similar interstitial lawmaking powers?

The second problem with the pre-Code practices doctrine is defining pre-Code practices. Simply put, the historical literature on pre-1978 bankruptcy practice is inadequate for this task. Even if it were adequate, there is still the question of how a pre-Code practice is defined. Are these practices to be interpreted narrowly or can they be broadened to analogous situations? For example, the Code contains no mention of substantive consolidation. ${ }^{338}$ Instead, it is "a caselaw

\footnotetext{
${ }^{338}$ See In re Raejean Bonham, 229 F.3d 750, 765 (9th Cir. 2000) ("even though substantive consolidation was not codified in the statutory overhaul of bankruptcy law in 1978, the equitable power undoubtedly survived enactment of the Bankruptcy Code."). But see 11 U.S.C. § 1123(a)(5)(C) (2000) ("Notwithstanding any otherwise applicable nonbankruptcy law, a plan shall—...provide adequate means
} 
doctrine[,] which has been developed over the years."339 Substantive consolidation started as a practice almost identical to veil piercing:

In the early years, when the doctrine of substantive consolidation was first evolving, the courts applied a test almost identical to the test for alter ego and/or piercing the corporate veil....In the older [pre-Code] cases, the application of substantive consolidation was limited to extreme cases involving fraud or neglect of corporate formalities and accounting procedures. ${ }^{340}$

The limited pre-Code application of substantive consolidation has been expanded under section 105(a) equitable powers to include consolidation of corporations that have observed the necessary corporate formalities and not engaged in fraud, when the creditors relied on corporate interconnectedness. In order to give tort victims greater compensation, the District of Delaware even extended substantive consolidation in In re Owens Corning to a situation in which there was reliance on formal separateness and neither fraud nor abuse of corporate formalities. ${ }^{341}$

for the plan's implementation, such as-...merger or consolidation of the debtor with one or more persons") (emphasis added).

${ }_{339}$ In re Standard Brands Paint Co., 154 B.R. at 567 (Bankr. C.D.Cal. 1993).

${ }^{340} I d$., at 568. Veil-piercing type substantive consolidation cases still occur. E.g., Raejean Bonham, 229 F.3d at 750. See In re Owens Corning, 419 F.3d at 205-09, for the history of substantive consolidation.

${ }^{341}$ See In re Owens Corning, 316 B.R. 168 (Bankr. D. Del. 2004) (granting substantive consolidation), rev'd, In re Owens Corning, 419 F.3d 195.

Even non-bankruptcy practices, such as the "doctrine of necessity," have been transformed into "pre-Code" practices and then expanded by analogy to areas that they did not historically cover. The doctrine of necessity was adopted from the related field of equity receiverships for railroads. See supra note 176. Two of the factors arguing for the importance of keeping a bankrupt railroad in operation, especially in the earlier half of the twentieth century, were the importance of the rails to the national economy and the difficulty for consumers in finding an immediate replacement. See, e.g., In re Boston \& Me. Corp., 634 F.2d 1359, 1374-78 (citing Gregg v. Metro. Trust Co., 197 U.S. 183, 196 (1905) (McKenna, J., dissenting) for the position that it declined to adopt, "[The] principle has its foundation in the public interests. A railroad, from its nature and public responsibilities, must be kept a going concern. This is the supreme necessity, and affords the test of the equity invoked for the claims for supplies.").

These factors underlay Judge Lynn's decision authorizing pre-plan payments to critical vendors in the bankruptcy of Mirant Corporation: "Debtors are among the most important providers of [electric] power in the United States and a disruption of the services provided by them could have a meaningful, adverse effect on segments of the national economy." In re Mirant Corp., 296 B.R. 427, 428 (Bankr. N.D. Tex. 2003). The concern about the national economy hearkens back to the railroad origins of the doctrine of necessity; electric power is even more vital to the national economy today than railroads were a century ago. While Judge Lynn cited as authority his own CoServ critical vendors decision, which held that the doctrine of necessity was only applicable for railroad reorganizations, 273 B.R. at 492, n7, he seems to have quietly reversed himself on this point in Mirant. In the wake of Mirant, is the doctrine of 
While bankruptcy courts' statutory equity powers cannot be grandfathered in under the pre-Code practices doctrine, the practices formerly authorized under the equity powers of the bankruptcy courts might present a different situation if they were widespread and are not repudiated by an affirmative provision in the Code. For example, the Ninth Circuit has noted that "[e]ven though [the practice of] substantive consolidation was not codified in the statutory overhaul of bankruptcy law in 1978, the equitable power [of substantive consolidation] undoubtedly survived enactment of the Bankruptcy Code. No case has held to the contrary.",342 Such is the case with virtually all pre-Code bankruptcy practices authorized under the color of equity. Difficulties have only arisen with attempts to apply the pre-Code practices doctrine to pre-Code equity receivership, i.e., non-bankruptcy practices. ${ }^{343}$

\section{Does the Pre-Code Practices Doctrine Imply a Living Federal Common Law of Bankruptcy?}

In the middle of the Court's string of decisions discussing the pre-Code practices doctrine was Ahlers. Ahlers touched on pre-Code practices only briefly, but its language is significant:

We think that the statutory language and the legislative history of $\S 1129$ (b) clearly bar any expansion of any exception to the absolute priority rule beyond that recognized in our cases at the time Congress enacted the 1978 Bankruptcy Code. $^{344}$

Not only does Ahlers comport with the general thrust of the Court's jurisprudence, that the pre1978 federal common law of bankruptcy continues to be valid, but there is also an important negative implication to Ahlers. Ahlers refused to allow a judicial expansion of the pre-1978

necessity is limited just to railroads, or may it and other pre-Code practices not explicitly rejected by the Code be expanded by analogy to new areas? If one can expand the doctrine of necessity to electric power, it seems reasonable to expand it to other instrumentalities of national commerce, such as air traffic, shipping, or trucking. But see B \&W Enters., 713 F.2d 534 (allowing for rescission of pre-plan critical vendor payments in a trucking case without ruling on authority to allow such payments).

${ }^{342}$ In re Bonham, 229 F.3d 759, 765 (9th Cir. 2000).

${ }^{343}$ See supra, note 176.

344485 U.S. at 206. 
exceptions to the absolute priority rule, but this was based on the existence of a codification of the absolute priority rule in the 1978 Code and a legislative history that supported the exclusive nature of the codification. This implies that pre-Code practices that are not codified can be expanded-that is, there is a living federal common law of bankruptcy in addition to the preCode practices doctrine.

\section{The Federal COMMON LAW OF BANKRUPTCY}

\section{A. CAN THERE BE A FEDERAL COMMON LAW OF BANKRUPTCY?}

\section{Defining Federal Common Law}

Definitions of federal common law vary, ${ }^{345}$ but as the Supreme Court uses the term, "in the strictest sense, [it is] a rule of decision that amounts, not simply to an interpretation of a federal statute, but rather to the judicial "creation" of a special federal rule of decision."346 The Supreme Court's definition focuses on one end of the spectrum between judicial interpretation and judicial lawmaking, ${ }^{347}$ as opposed to the broader definition suggested by Martha Field: "any rule of federal law created by a court... when the substance of that rule is not clearly suggested by federal enactments- constitutional or congressional."348 Field's definition "includes much we think of as interpretation; it leaves no clear-cut line between federal common law and federal interpretational law."349

The Supreme Court's definition encompasses both interstitial lawmaking and more traditional common lawmaking, such as creation of new rights of action or rules of decision. Non-Code practices tend to fall within the narrower ambit of the Court's definition. They range

\footnotetext{
${ }^{345}$ Field, supra note 73 , at 889.

${ }^{346}$ Burlington Indus., Inc. v. Ellerth, 524 U.S. 742 (1998).

${ }^{347}$ See supra text accompanying notes 72-75.

${ }^{348}$ Field, supra note 73, at 890. Cf. Redish, supra note 73.

${ }^{349}$ Field, supra note 73, 893-94.
} 
from interstitial lawmaking, that is filling in the gaps where Congress has not spoken but working with the statutory structure-e.g., pre-plan payments for pre-petition debts or crosscollateralization - to creating rules of decision and rights of action-substantive consolidation, non-debtor releases, and channeling injunctions other than those issued under 11 U.S.C. $\S$ $524(\mathrm{~g})$

\section{The Status of Federal Common Law Post-Erie}

It is hornbook law going back to Justice Brandeis' proclamation in Erie R. Co. v. Tompkins that there is "no federal general common law.",350 But it is also well established that there is federal common law in a "few and restricted" 351 specific areas. ${ }^{352}$ As the Supreme Court explained in Texas Industries, Inc. v. Radcliff Materials, Inc., these areas:

fall into essentially two categories: those in which a federal rule of decision is "necessary to protect uniquely federal interests" and those in which Congress has given the courts the power to develop substantive law.

The vesting of jurisdiction in the federal courts does not in and of itself give rise to authority to formulate federal common law, nor does the existence of congressional authority under Art. I mean that federal courts are free to develop a common law to govern those areas until Congress acts. Rather, absent some congressional authorization to formulate substantive rules of decision, federal common law exists only in such narrow areas as those concerned with the rights and obligations of the United States, interstate and international disputes implicating the conflicting rights of States or our relations with foreign nations and admiralty cases. ${ }^{353}$

Thus, there are two areas by which federal common lawmaking power can exist: when

350304 U.S. 64, 78 (1938). While Erie revolved around the federalism concerns of federal general common law applying to diversity jurisdiction cases, it also has separation of powers implications. This article focuses solely on the separation of powers implications and does not address the relationship of federal and state law. See supra note 11.

${ }^{351}$ Wheeldin v. Wheeler, 373 U.S. 647, 651 (1963).

${ }^{352}$ United States v. Standard Oil Co., 332 US 301, 308 (1947).

${ }^{353}$ Texas Indus., 451 U.S. at 641. 
necessary to protect a uniquely federal interest and when Congress has authorized it. ${ }^{354}$

\section{Where Does Bankruptcy Fall in the Texas Industries Analysis?}

Can there be a federal common law of bankruptcy under Texas Industries ${ }^{355}$ This article argues yes on the basis of the language of the Bankruptcy Clause, the legislative history of the Bankruptcy Code, the pre-Code practices doctrine, and the nature of bankruptcy practice.

Generally, federal common law is considered in the context of whether courts should apply federal common law instead of state law as the rule of decision. This question in the bankruptcy context is beyond the scope of this article. ${ }^{356}$ Rather, the question this article aims to address is when there is no state law to provide a rule of decision, can federal courts in

${ }^{354}$ In spite of the Supreme Court's acceptance of federal common lawmaking in limited enclaves, the very possibility of federal common law is still questioned. Martin Redish, supra note 73, at 766-67, has argued that any federal common lawmaking is a violation of the Rules of Decision Act (RDA), which provides that "[t]he laws of the several states, except where the Constitution or treaties of the United States or Acts of Congress otherwise require or provide, shall be regarded as rules of decision in civil actions in the courts of the United States where they apply." 28 U.S.C. $§ 1652$ (2000).

Although far beyond the scope of this article, I would posit that the RDA is unconstitutional to the extent that it is a per se bar on federal common lawmaking, as common lawmaking is a core part of the Article III "judicial power" and cannot be removed by act of Congress. In any event, federal common lawmaking in bankruptcy would not be barred even by Redish's proposed stricture. First, the Rules of Decision Act originally referred to "trials at common law" not "civil actions." The change was only made in 1948, 62 Stat. 944 (June 25, 1948). Thus, the RDA did not originally apply to bankruptcy, which was not a "trial at common law." In re De Gottardi, 114 F.328 (D.Cal. 1902). But cf. Peachtree Lane Assocs. v. Granader (In re Peachtree Lane Assocs.) 186 B.R. 663 (Bankr. N.D.Ill.) (rejecting contention that current RDA does not apply in bankruptcy because it only governs Article III courts).Assuming that bankruptcy is a "civil action" in the meaning of the statute, which itself could be debated, it is doubtful that Congress intended the RDA to extend to bankruptcy even if it wanted to expand the scope of the RDA's application. Second, bankruptcy is a case where Congress has provided for federal common lawmaking, and third, this is a case where an act of Congress requires federal common law, both as a matter of statutory structure vis-à-vis state law and as a matter of practical necessity, points that are taken up in the text below.

${ }^{355}$ Erie itself arguably does not apply to bankruptcy, as bankruptcy jurisdiction is federal question, not diversity. See In re Zaepfel \& Russell, Inc., 49 F. Supp. 709 (D.Ky. 1941), aff'd 136 F.2d 215 (6th Cir. 1943).

${ }^{356}$ See Cross, supra note 266, at 1227 (noting that state-law claims in bankruptcy are not proper areas for the creation of federal common law); also see supra note 11.

(C) 2006, Adam J. Levitin 
bankruptcy create a federal common law that goes beyond the letter of the Code ${ }^{357}$ To put this into some perspective, state law and federal non-bankruptcy law generally determine the existence and size of claims, ${ }^{358}$ but bankruptcy law provides the priority of claims, which is crucial when there is a limited pot. For example, property rights such as security interests are created by state law, but federal law (including Erie) determines their status in bankruptcy.

The possibility of a federal common law of bankruptcy is an open question. The Supreme Court has never directly addressed the issue, and the courts of appeals are split. The Second $^{359}$ and Third ${ }^{360}$ Circuits have acknowledged a federal common law of bankruptcy in their dicta to illustrate parallel non-bankruptcy common law practices. The Eighth Circuit has rejected the existence of a specific delegation of power to create a federal common law right to extend state redemption periods in Chapter 12 farm bankruptcies under 11 U.S.C. 1222(b)(3) and (5), but the provision by provision approach implies an acceptance in principle that there could be federal common lawmaking power in bankruptcy, at least under Texas Industries' second path, even if it did not exist in this instance. ${ }^{361}$ In contrast, the Sixth Circuit created the very right that the Eighth Circuit denied, albeit without any discussion of its authorization to make

\footnotetext{
${ }^{357}$ This article does not address other areas of federal common law that interact with bankruptcy, such as federal common law of procedure or patents and copyrights.

${ }^{358}$ See Butner, 440 U.S. at 54-55.

${ }^{359}$ Compagnie Noga D'Importation et D'Exportation S.A. v. The Russian Fed., 361 F.3d 676, 688 (2d Cir. 2004) ("we note that an issue similar to the one before us has arisen in the federal common law of bankruptcy and set off.") (noting parallelism between treatment of different federal agencies as constituent parts of the same entity under federal common law of bankruptcy and treatment of the Russian Federation and the Government of Russia as part of same entity for arbitration purposes).

${ }^{360}$ Nesbit v. Gears Unlimited, Inc., 347 F.3d 72, 87 (3d Cir. 2003) (noting that substantive consolidation for Title VII purposes, like in bankruptcy, is one of federal common law, although it is an "intentionally open-ended, equitable inquiry"). But cf. In re Cont'l Airlines, 91 F.3d 553, 570-71 (3d Cir. 1996) (en banc) (Alito, J., dissenting) (“...the court seemed to say that the Bankruptcy Code contains an 'interstice'a gap-regarding the circumstances under which an appeal that might upset a plan of reorganization may be pursued. Further, the court appeared to suggest that the federal courts have the authority to create a rule of federal common law to fill this gap.").

${ }^{361}$ Justice v. Valley Nat'l Bank, 849 F.2d 1078, 1087-88 (8th Cir. 1988).
} 
federal common law. ${ }^{362}$ Other courts have certainly engaged in what can only be described as federal common lawmaking without ever addressing the issue. ${ }^{363}$

The Fifth Circuit is the only circuit court of appeals to take up the question of whether there is a general delegation of federal common lawmaking power in bankruptcy. In Walker $v$. The Cadle Co. (In re Walker), the issue before the Fifth Circuit was whether there was a right of action for contribution between joint violators of the automatic stay. ${ }^{364}$ The Fifth Circuit was facing the same question as the Supreme Court in Texas Industries-whether a right to contribution existed under federal common law-but in a bankruptcy, rather than an anti-trust, context. This might have constrained the Fifth Circuit more than if Walker had dealt with the creation of a right without a parallel, non-bankruptcy situation previously addressed by the Supreme Court.

Nonetheless, based on the absence of legislative history indicating that Congress intended to create such a right and the obvious purpose of the automatic stay to protect debtors, not violators, of the stay, the Fifth Circuit held that there was no such right. ${ }^{365}$ The Fifth Circuit observed that because there was no statutory right, it could only exist under federal common law, but that under Texas Industries, courts have a restricted ability to make federal common law: ${ }^{366}$

We do not wantonly use our power to fashion common-law remedies, for the Supreme Court has cautioned us to invoke the power of the "federal common law" only when either "a federal rule of decision is necessary to protect uniquely federal interests, [or] ... Congress has given the courts the power to develop substantive law." This grant of power is very narrow, and although bankruptcy might seem to be a "uniquely federal interest," the Court has stated that, "the existence of congressional authority under Art. I [does not] mean that federal

\footnotetext{
${ }^{362}$ In re Glenn, 760 F.2d 1428, 1435 (6th Cir. 1985) (balancing the equities regarding curing default in absence of Congressional directive).

${ }^{363}$ E.g., In re Owens-Corning and the entire line of substantive consolidation cases cited therein, 419 F.3d at 206-209.

${ }^{364} 11$ U.S.C. $\$ 362(2000)$.

36551 F.3d 562, 566 (5th Cir. 1995).

${ }^{366} I d$. at 566-567.
} 
courts are free to develop a common law to govern those areas until Congress acts....Simply put, bankruptcy is not an area where the courts have wide discretion to fashion new causes of action. ${ }^{367}$

The Fifth Circuit then noted that "in enacting the Bankruptcy Code[,] Congress created a comprehensive legislative program...."368 For the Fifth Circuit, codification foreclosed the possibility of federal common law in bankruptcy. ${ }^{369}$ It is not clear, though, why this would not have been the case with the 1898 Act too, as bankruptcy exists only as a matter of statute. While federal common law may add on to that statutory structure, it does not create bankruptcy relief where none existed before.

Whatever the merits of the Fifth Circuit's decision regarding the right to contribution, there are serious analytical problems in Walker's treatment of federal common lawmaking power. Texas Industries laid out two separate ways in which federal common lawmaking was authorized. First, there are cases "in which a federal rule of decision is necessary to protect uniquely federal interests." 370 Second there are cases "in which in which Congress has given the courts the power to develop substantive law."371 The Fifth Circuit's analysis of both paths was cursory, and, more to the point, erroneous. Federal common lawmaking in bankruptcy is proper under both of Texas Industries' paths, as detailed below.

\section{Path 1: Constitutional Sources for a Federal Common Law of Bankruptcy}

The Fifth Circuit noted that bankruptcy is not explicitly included in Texas Industries' list of areas in which courts are free to develop federal common law under the first path. Bankruptcy

\footnotetext{
${ }^{367}$ Id. at 567 (5th Cir. 1995) (citing Texas Indus., 451 U.S. at 640) (bracketed language in original).

${ }^{368}$ Id. at 567 (quoting Wieboldt Stores, Inc. v. Schottenstein, 111 Bankr. 162, 168 (N.D. Ill. 1990).

${ }^{369}$ Walker might not have foreclosed all federal common lawmaking in bankruptcy; while courts may not have "wide discretion" to do so, according to Walker, they may still have some discretion in the matter, although the opinion gives no indication as to where the line between discretion and wide discretion lies. ${ }^{370}$ Texas Indus., 451 U.S. at 641.

${ }^{371} I d$.
} 
is not necessarily "concerned with the rights and obligations of the United States, interstate and international disputes implicating the conflicting rights of States or [ ] relations with foreign nations and admiralty cases." ${ }^{372}$ The Fifth Circuit, however, treated the Texas Industries' list is exclusive, not illustrative. ${ }^{373}$ But the language of the Supreme Court's list that "absent some congressional authorization...federal common law exists only in such narrow areas as" makes clear that it was only providing examples, not defining the boundaries of federal interests engendering common lawmaking power. ${ }^{374}$

Assuming Texas Industries' list is illustrative, it does not answer the question of whether bankruptcy is an area of "uniquely federal interests" such that common lawmaking power should be presumed. This article argues that this power should be presumed is because bankruptcy has been relegated to an exclusively federal role once Congress acted under the Bankruptcy Power.

Article I, section 8, clause 4 of the Federal Constitution vests Congress with the power "To establish an uniform Rule of Naturalization, and uniform Laws on the subject of Bankruptcies throughout the United States." ${ }^{375}$ The key element in the Bankruptcy Clause is that it empowers Congress to pass uniform bankruptcy laws. ${ }^{376}$ The uniformity provision leaves little room for non-federal bankruptcy law, and thereby makes bankruptcy a "uniquely federal interest." Although the precise dimensions of the uniformity remain uncharted, ${ }^{377}$ the Supreme Court's decision in Central Virginia Community College v. Katz noted that the history of the

${ }^{372}$ Id.

${ }^{373} 51$ F.3d at 567.

${ }^{374} 451$ U.S. at 641 (emphasis added).

${ }^{375}$ U.S. CONST. art. I, § 8, cl. 4.

${ }^{376}$ The existence of Congressional power to legislate on bankruptcies does not alone grant federal courts common lawmaking power in bankruptcy. 451 U.S. at 641 (“...nor does the existence of congressional authority under Art. I mean that federal courts are free to develop a common law to govern those areas until Congress acts.").

${ }^{377}$ Cent. Va. Cmty. Coll. v. Katz, 546 U.S. _ (2006), No. 04-885, slip op. at 19 n.13 (Jan. 23, 2006). Butner, 440 U.S. at 54 n.9, 55 (uniformity requirement does not prevent bankruptcy law from incorporating the laws of the states despite variants in state law).

(C) 2006, Adam J. Levitin 
Bankruptcy Clause demonstrated that bankruptcy was an important enough federal interest that the states yielded their sovereign immunity in bankruptcy. ${ }^{378}$ Indeed, it was an important enough interest to receive particular mention in the Constitution.

As the Court noted in Katz, the uniformity interest in bankruptcy is particularly strong because of the pre-Constitution history of bankruptcy and insolvency law. Whereas England had one sovereign and was subject to one uniform bankruptcy law, ${ }^{379}$ each of the states enacted its own bankruptcy or insolvency law. ${ }^{380}$ This led to the 18th century equivalent of forum shopping — debtors would abscond to more favorable jurisdictions, and the fear of debtors' flight was a major factor supporting debtors' prisons. ${ }^{381}$ Rather than allow the Full Faith and Credit Clause to govern such disputes, which would have continued the problem of debtors' forum shopping, the Constitution instead opted to give Congress the power to create a uniform federal rule that would govern all bankruptcies. ${ }^{382}$ Indeed, the extent of the unique federal interest in bankruptcy is demonstrated by the authorization under the first bankruptcy act for federal courts to issue writs of habeas corpus to release debtors from state prisons, thereby overriding state criminal law, to facilitate their attendance at bankruptcy proceedings. ${ }^{383}$

The uniformity element, in conjunction with the provisions of the Code, operates to make bankruptcy exclusively, and therefore uniquely, federal. Bankruptcy is essentially an in rem proceeding. ${ }^{384}$ Unlike equity receiverships at state law, bankruptcy has jurisdiction not over just specific items of property, but over the debtor and all the debtor's property interests. ${ }^{385}$ Once an

\footnotetext{
${ }^{378}$ Katz, 546 U.S. __ (2006), No. 04-885, slip op. at 20 (Jan. 23, 2006).

${ }^{379} \mathrm{Id}$. at 8.

${ }^{380} I d$. at 7.

${ }^{381} I d$.

${ }^{382} I d$. at $10-11$.

${ }^{383} \mathrm{Id}$. at 5 .

${ }^{384}$ Id. at 4; Tenn. Student Assistance Corp. v. Hood, 541 U. S. 440, 448 (2004).

${ }^{385}$ Buckner, 61 U.S. (20 How.) at 122.
}

(C) 2006, Adam J. Levitin 
order for bankruptcy relief is granted, any sort of state insolvency proceeding must give way to the bankruptcy proceeding because all assets of the bankruptcy estate are subject to federal jurisdiction. $^{386}$ The automatic stay enjoins any state insolvency proceeding ${ }^{387}$ while a bankruptcy is pending, and the discharge injunction ${ }^{388}$ prevents any state insolvency proceeding based on pre-petition debts. ${ }^{389}$

Thus, the only way that a state insolvency proceeding can go forward once an order for bankruptcy relief is granted is for the bankruptcy court to lift the stay, which it is unlikely to do without consent of all creditors and the debtor; doing so eviscerates any meaningful bankruptcy jurisdiction and the Code's priority scheme ${ }^{390}$ because it allows certain creditors to jump to the head of the line. Thus, there can only be parallel state and federal insolvency proceedings when a federal court chooses to relinquish its jurisdiction. This contrasts with areas of law like antitrust, in which there are both federal and state causes of action and potentially parallel federal and state proceedings for the same conduct. Bankruptcy's nature of exclusive jurisdiction over the debtor's assets makes it a uniquely federal concern because it allows no room for state action.

In some sense, the case for bankruptcy being a uniquely federal interest is a preemption argument. States are not per se preempted from passing and enforcing their own insolvency and bankruptcy laws; they are only barred from applying those laws once federal bankruptcy

\footnotetext{
386 11 U.S.C. $\$ 541$ (2000).

${ }^{387}$ State regulatory proceedings are a different matter under 11 U.S.C. § 362(b)(4) (2000) (exempting from the automatic stay the "commencement or continuation of an action or proceeding by a governmental unit...to enforce such governmental unit's...police and regulatory power"). See Pac. Gas \& Elec. Co. v. People of the State of Cal. ex rel. Cal. Dept. of Toxic Substances Control, 350 F.3d 932 (2003).

38811 U.S.C. $\S 524(\mathrm{a})(2)(2000)$.

${ }^{389}$ The possible exception to this would be a state insolvency proceeding based on pre-petition executory contracts or leases that "rode through" bankruptcy because they were neither assumed nor rejected by the trustee. See Bildisco, 465 U.S. at 546 n.12 (Brennan, J., concurring in part and dissenting in part) (noting the possibility of ride-through).

${ }^{390} 11$ U.S.C. $\$ 507$ (2000).
} 
jurisdiction is triggered. ${ }^{391}$ That is to say, there is not traditional explicit, field, or conflict preemption, but an amalgam best described as a functional preemption; the explicit provisions of the Code create a conflict preemption when there is federal bankruptcy jurisdiction. The Code's functional preemption means that Congress essentially occupies the field. ${ }^{392}$ The uniformity element that is required in any Constitutional bankruptcy law combined with the in rem nature of bankruptcy and the Code's expansive definition of the bankruptcy estate, automatic stay, and discharge injunction make bankruptcy a "uniquely federal interest."

This reading conforms with the rest of the Article I, $\S 8$, Clause 4, which deals with establishing a "uniform Rule of Naturalization". ${ }^{393}$ The inclusion of these two topics, naturalization and bankruptcy in the same clause and the parallel construction suggests a parity between the issues. No one would doubt that naturalization is a "uniquely federal interest." It follows then that bankruptcy too is a "uniquely federal interest."

\section{Path 2: Statutory Sources for a Federal Common Law of Bankruptcy}

If bankruptcy is a "uniquely federal interest," then it does not matter if Congress authorized federal common lawmaking. If bankruptcy is not a "uniquely federal interest" engendering common lawmaking powers, though, it may still be authorized by Congress's action. There is no question that Congress has the power under the Bankruptcy Clause to authorize federal common lawmaking in bankruptcy; the question under Texas Industries' second path is whether it did.

It is not clear how explicit an authorization is required by Texas Industries. Field has noted, "[i]f [Texas Industries] is a directive standard, it clearly requires only an implicit rather

${ }^{391}$ Cf. Butner, 440 U.S. at 54 n.9 ("state laws are thus suspended only to the extent of the actual conflict with the system provided by the Bankruptcy Act of Congress.").

${ }^{392}$ See Cent. Va. Cmty. Coll. v. Katz, 546 U.S.__ (2006), No. 04-885, slip op. at 12 (Jan. 23, 2006).

${ }^{393}$ U.S. CONST. art. I, § 8, cl. 4. 
than explicit legislative directive." ${ }^{394}$ If so, there arguably is such an authorization in the case of bankruptcy. While the case for such an authorization involves some significant assumptions, it does accord with the legislative history, the pre-Code practices doctrine, and the practical realities of bankruptcy.

The pre-Code practices doctrine indicates that Walker's general "presumption that a remedy was deliberately omitted from a statute is strongest when Congress has enacted a comprehensive legislative scheme" ${ }^{395}$ does not apply to bankruptcy. Congress has repeatedly amended the Bankruptcy Code since the string of cases that have enunciated the pre-Code practices doctrine. Congress is aware of the pre-Code practices doctrine and has done nothing to curtail it. ${ }^{396}$ Could this interpretive move also apply to finding a grant of common lawmaking powers absent an express directive? Congress could have been clearer on this point, but there is arguably a delegation of lawmaking power to the bankruptcy courts via equity powers.

As noted above, the House Report on the Bankruptcy Act of 1978 cited 28 U.S.C. § 1481 as authority for its statement that "[t]he bankruptcy court will remain a court of equity." ${ }^{397}$ If one gives the legislative history credence, this comment, when read literally, does not speak to common lawmaking power or show that federal courts sitting in bankruptcy jurisdiction are in any way different from regular federal courts with equity jurisdiction. As this article has argued, however, the use of the term "equity" in the bankruptcy context is really "fortuitous coinage" for what is better described as federal common lawmaking. Generally, it is reckless to read

\footnotetext{
${ }^{394}$ Field, supra note 73, at 934 n.226.

${ }^{395} 51$ F.3d at 567.

${ }^{396}$ See, e.g., Brown \& Williamson Tobacco, 529 U.S. at 125-26.

${ }^{397}$ H.R. REP. NO. 95-595, at 359 (1977), reprinted in U.S.C.C.A.N. 5963, 6315 ("This section[, proposed 11 U.S.C. 510(b),] is intended to codify case law, such as Pepper v. Litton, 308 U.S. 295 (1939) and Taylor v. Standard Gas and Electric Co., 306 U.S. 295 (1939) and is not intended to limit the [bankruptcy] court's power in any way. The bankruptcy court will remain a court of equity, proposed 28 U.S.C. 1481; Local Loan v. Hunt, 292 U.S. 234, 240 (1934).”).
} 
Congress's use of term $X$ to mean $Y$. But in this case, the term "equity" in the context of bankruptcy jurisdiction and powers is a term of art that means "federal common law." Thus, a "court of equity" is better understood as a "court with federal common lawmaking power."

For example, in Butner v. United States, the issue before the Supreme Court was whether state or federal law should govern the rights to the rents collected between a mortgagor's bankruptcy and the foreclosure sale of the mortgaged property. ${ }^{398}$ A circuit split existed on the issue. Five circuits had determined the issue by looking to state law, whereas " $[\mathrm{t}]$ he Third and Seventh Circuits ha[d] adopted a federal rule of equity that affords the mortgagee a secured interest in the rents even if state law would not recognize any such interest until after foreclosure." "399 This "federal rule of equity" is more aptly described as "federal common law"; what the Third and Seventh Circuits did was create a rule of decision. Although the Supreme Court rejected this "federal rule of equity" in Butner because of Erie concerns about its interplay with state law, the point remains that bankruptcy powers authorized as equity are better thought of as authorized by federal common law. Butner only rejected federal common law in bankruptcy to the extent it conflicted with state law in that case; the implication in its ruling is that federal common law may exist in bankruptcy when it does not conflict with state law.

Thus, reading "equity" as a term of art in the bankruptcy jurisdiction and powers context, the legislative history was stating that "the bankruptcy court will remain a court with common lawmaking powers." This reading comports with the pre-Code practices doctrine, which has in effect been ratified by Congress' repeated amendments to the Bankruptcy Code that have left the doctrine unchanged or even codified non-Code practices. ${ }^{400}$ Moreover, because this reading is anchored in the legislative history, it can survive the possible repeal of 28 U.S.C. $\S 1481$.

\footnotetext{
398440 U.S. at 49.

${ }^{399} \mathrm{Id}$. at 53 (emphasis added).

${ }^{400}$ E.g., 11 U.S.C. $§ 524(g)(2000)$.
}

(C) 2006, Adam J. Levitin 
When 28 U.S.C. $\S 1481$ is seen in conjunction with the history of the Bankruptcy Code, and viewed with the added factor of Congressional ratification by inaction in its subsequent revisions to the Bankruptcy Code, there is a case to be made that Congress intended federal courts to have some sort of lawmaking authority in bankruptcy, even if this intention was only vaguely articulated. Admittedly, no one of these elements, analyzed by itself, is sufficient for finding an implicit directive, but the picture from the combined total is greater than the sum of its parts, and when viewed in conjunction with the special bankruptcy concerns that explain why Congress would want to delegate such powers, it is plausible that there has been a delegation of lawmaking power to federal courts in bankruptcy cases.

Arguably, by placing bankruptcy proceedings in courts, rather than an agency, Congress intended the existence of the common law power inherent in the judicial power, for as the Supreme Court has noted, even Article I courts possess the judicial power. ${ }^{401}$ Bankruptcy referees under the 1898 Act exercised wide-ranging discretion. ${ }^{402}$ As Alan Schwartz has noted:

Congress in 1978 wanted to elevate the stature of the bankruptcy courts rather than reduce it. This goal produced the replacement of the bankruptcy referee system with "real judges" who are appointed for substantial terms and paid high salaries. To grant these new judges less authority to make policy than the referees they replaced would have been irrational. ${ }^{403}$

In short, it is hard to think that Congress would not have wanted federal judges to have common lawmaking power in bankruptcy. Of course, such common lawmaking power is tempered by the strictures of the Code ${ }^{404}$ and by the scope of the bankruptcy power itself. ${ }^{405}$

\section{Explaining the Pre-Code Practices Doctrine Without Federal Common Law}

\footnotetext{
${ }^{401}$ Freytag, 501 U.S. at 889 (1991).

${ }^{402}$ See Wiensch, supra note 166, at 1831.

${ }^{403}$ Schwartz, supra note 337, at 186.

${ }^{404}$ E.g., Ahlers, 485 U.S. at 206.

${ }^{405}$ See Plank, supra note 11 at 662; Thomas E. Plank, The Security of Securitization and the Future of Security, 25 CARDOZO L. REV. 1655, 1724 (2004).
}

(C) 2006, Adam J. Levitin 
Federal courts have common lawmaking powers in bankruptcy under the "uniquely federal interests" path of Texas Industries and perhaps too under the "Congressional authorization" path. Indeed, they must, for if they did not and the Fifth Circuit were correct in Walker, how does one explain the pre-Code practices doctrine, which recognizes pre-Code federal bankruptcy common law even after codification? The only viable explanation is a sort of "water-over-the-dam" approach like the Supreme Court took in Northwest Airlines, Inc. $v$. Transport Workers Union of America, AFL-CIO. In that case, the Supreme Court noted that:

it is much too late to deny that there is a significant body of federal law that has been fashioned by the federal judiciary in the common-law tradition, [but] it remains true that federal courts, unlike their state counterparts, are courts of limited jurisdiction that have not been vested with open-ended lawmaking powers...the federal lawmaking power is vested in the legislative, not the judicial branch of government; therefore, federal common law is 'subject to the paramount authority of Congress.' 406

Of course, the Northwest Airlines approach says nothing about how to treat past judge-made law. Is it still valid? Is it grandfathered in under principles of stare decisis? If deference were given to stare decisis, it does not explain the pre-Code practices doctrine, as codification presented an opportunity to approach bankruptcy practice with a clean slate without the accretions of precedents formed under the 1898 Act.

In that case, can past judge-made bankruptcy law be challenged as applied to new parties on the basis of being judicially created? It is hard to strike down the entirety of the "significant body of federal law that has been fashioned by the federal judiciary in the common-law tradition."407 Not only have parties relied on the law as it has developed, but Congress has ratified much of this law both by subsequent codifications that incorporate it and by inaction. It

\footnotetext{
406451 U.S. 77, 96 (1981). Also Corr. Serv. Corp. v. Malesko, 534 U.S. 61, 75 (2001) (Scalia, J, concurring) (the federal common law right of action created in Bivens v. Six Unknown Named Agents of the Federal Bureau of Narcotics, 403 U.S. 388 (1971), is "a relic of the heady days in which this Court assumed common-law making powers to create causes of action.").

${ }^{407} 451$ U.S. at 96.
} 
seems unlikely that past federal common lawmaking is to be invalidated. The "water-over-thedam" approach lacks any intellectual consistency. Like the pre-Code practices doctrine and Grupo Mexicano, it allows development up to an arbitrary line. Such an approach of Constitutional convenience is anathema to a purist view of the Constitution and is an untenable method of Constitutional adjudication; our law must be based on better principles.

\section{B. FEDERAL COMMON LAW OF BANKRUPTCY IN ACTION}

What does federal common lawmaking look like in action? One example we have seen is the Seventh Circuit's opinion in K-Mart v. Capital Factors. In K-Mart, Judge Easterbrook created a common law evidentiary requirement for critical vendor motions, ${ }^{408}$ even if the tenor of the opinion's rhetoric came out strongly against such motions. K-Mart thus created a rule of decision for critical vendor motions: without an adequate showing of necessity supported by some sort of evidence, a critical vendor motion cannot be granted in the Seventh Circuit. Implied in this rule of decision is a non-Code right to make pre-plan payments for pre-petition debts upon a showing of necessity to the debtor's reorganization. In this sense, the Seventh Circuit actually authorized a significant deviation from the Code's priority scheme.

Likewise, Bankruptcy Court for the District of Delaware's treatment of non-debtor releases in Genesis Health Ventures is an example of the creation of federal common law. The Bankruptcy Code does not provide one way or another for releases of non-debtors. The Code does provide a discharge injunction for the debtor that prevents actions to recover on pre-filing

debts. ${ }^{409}$ The Code also allows for channeling injunctions that requires all claimants to look to a

\footnotetext{
${ }^{408}$ Federal rules of evidence have long been an area in which common lawmaking has been permitted. See FED. R. EVID. 501 (evidentiary privileges in federal-question cases).

409 11 U.S.C. $\$ 524(a)(2)(2000)$.
} 
settlement trust, but only in asbestos related bankruptcies. ${ }^{410}$ Otherwise, the Code specifically provides that the "discharge of a debt of the debtor does not affect the liability of any other entity on...such debt."411 These provisions do not address the question of liability of non-debtors for debts not incurred by the debtor. ${ }^{412}$ Nor should they; one would think that bankruptcy courts would only have jurisdiction over bankruptcy estate, not disputes between third parties unrelated to claims on the estate. Accordingly, several circuits do not permit releases of non-debtors. ${ }^{413}$

On the other hand, such disputes are often related to claims on the estate because the outcomes can affect the business operations of the estate. Corporate debtors exist as a matter of law, but their actual operations are a function of people. Sometimes, in order for a debtor's reorganization to succeed, it needs specific personnel. If these personnel are distracted by lawsuits, they may not be able to render effective services to the debtor.

Having determined that section 105 (a) powers were inapplicable to the situation, ${ }^{414}$ the Genesis Health Ventures court navigated these competing concerns by carefully laying out the factors that courts have considered when reviewing such releases and attempting to divine a multi-factor test—a rule of decision for when to permit such releases. ${ }^{415}$

A final example is the Third Circuit's Owens Corning decision, reversing the District Court's grant of the debtor's substantive consolidation motion. In Owens Corning, the debtor and most of its creditors moved for the substantive consolidation of the debtor and all its myriad

\footnotetext{
${ }^{410} 11$ U.S.C. $\$ 524(\mathrm{~g})$ (2000).

${ }^{411} 11$ U.S.C. $\$ 524(\mathrm{e})(2000)$.

${ }^{412}$ In re PWS Holding Corp., 228 F.3d 224, 245 (3d Cir. 2000) (11 U.S.C. § 524(e) "only provides that a discharge of the debtor does not affect the liability of non-debtors on claims by third parties against them for the debt discharged in bankruptcy.").

${ }^{413}$ See, e.g., In re Lowenschuss, 67 F.3d at 1401; In re Zale Corp., 62 F.3d at 760; In re Western Real Estate Fund, Inc., 922 F.2d at 600, modified by Abel v. West, 932 F.2d 898 (10th Cir.1991).

${ }^{414}$ Genesis Health Ventures, 266 B.R. at 603.

${ }^{415} \mathrm{Id}$. at 603-07
} 
subsidiaries, which had jointly filed for bankruptcy. ${ }^{416}$ Doing so would have created a larger combined pool of assets from which all general unsecured creditors could have drawn, regardless of the assets of the entity with whom they had transacted. The motion was opposed by some of Owens Corning's bank creditors. ${ }^{417}$ The bank creditors had made loans to Owens Corning and only five of its subsidiaries, all of which cross-guaranteed the others' loans. ${ }^{418}$ Without substantive consolidation, there would be fewer claimants on assets held by Owens Corning and the five subsidiaries, and the banks would have a larger recovery than if they had to share with all the other creditors in the assets of all consolidated debtors. The District Court granted the substantive consolidation motion in a situation in which there was reliance on formal separateness and neither fraud nor abuse of corporate formalities. ${ }^{419}$

In a carefully considered opinion, the Third Circuit reversed. The Third Circuit noted that "[s]ubstantive consolidation, a construct of federal common law, emanates from equity." This is the only occasion in which a federal court ruling on a non-Code practice has described the non-Code practice in terms of federal common law. Notably, even in this case, there is an intertwining of federal common law and equity in the description of the non-Code practice. Substantive consolidation is historically an equity-derived practice, ${ }^{421}$ but it has become part of bankruptcy via federal common law. The Third Circuit noted that a multi-factor checklist was unsatisfactory for analyzing substantive consolidation cases because they are intensely factintensive. $^{422}$ Instead, the Third Circuit articulated five principles to guide analysis of substantive

\footnotetext{
${ }^{416}$ In re Owens Corning, 316 B.R. at 169.

${ }^{417} I d$.

${ }^{418} I d$. at 170.

${ }^{419} I d$. at 173.

${ }^{420}$ In re Owens Corning, 419 F.3d at 205.

${ }^{421} I d$. at 206-09.

${ }^{422} I d$. at $210-11$.
} 
consolidation motions and laid down the conditions required for granting such a motion. ${ }^{423}$ In doing so, the Third Circuit created a non-Code right and a corresponding rule of decision.

\section{REConCILING EQUity WITH a Government of Codes: Federal Common LaW}

"The most important question regarding judicial discretion is universal: will judges utilize their discretion to make public policy rather than defer to other institutions?"424 However one choose to answer this question as a general matter, bankruptcy presents a unique situation in which the structure of the bankruptcy system and the nature of bankruptcy cases weigh in strongly for urging judges to take the lead in lawmaking, albeit with proper deference to the policies that Congress has embodied in the Code.

While common lawmaking power in bankruptcy is a matter of Constitutional and statutory interpretation, the realities of bankruptcy practice also call for the existence and use of such power. Long ago, the Supreme Court noted the importance of the flexibility of the Bankruptcy Clause to encompass new developments in business:

...[T]he capacity of the bankruptcy clause to meet new conditions as they have been disclosed as a result of the tremendous growth of business and development of human activities from 1800 to the present day. And these [prior bankruptcy acts], far-reaching though they be, have not gone beyond the limit of congressional power; but rather have constituted extensions into a field whose boundaries may not yet be fully revealed. ${ }^{425}$

Bankruptcy is extremely fact-specific. ${ }^{426}$ The nature of bankruptcy requires flexibility and discretion. Bankruptcy is about how to divide efficiently and fairly a fund that is too small to

\footnotetext{
${ }^{423} I d$. at 211.

${ }^{424}$ Jared Wessel, Judicial Policy-Making at the International Criminal Court: An Institutional Guide to Analyzing International Adjudication, 45 COLUM. J. TRANSNAT'L L. (2006) (forthcoming) (manuscript on file with author, at 3 ).

${ }^{425}$ Cont'l Ill., 294 U.S. at 671 (internal citations omitted).

${ }^{426}$ See Butner, 440 U.S. at 55-56 ("The equity powers of the bankruptcy court play an important part in the administration of bankrupt estates in countless situations in which the judge is required to deal with particular, individualized problems."). Also Harvey R. Miller- The Changing Face of Chapter 11: A Reemergence of the Bankruptcy Judge as Producer, Director, and Sometimes Star of the Reorganization Passion Play, 69 AM. BANKR. L.J.431 (1995).
} 
satisfy all claimants. ${ }^{427}$ Satisfying multiple claimants from a limited fund always involves balancing the interests of the claimants, as well as the debtor in Chapter 11 and Chapter 13 cases. Such balancing cannot always be done robotically according to the Code's formulas.

The Code itself calls for judicial discretion in numerous instances. ${ }^{428}$ In addition to the various provisions calling on the court to act if it determines that the act in question is "fair and equitable" or the like, ${ }^{429}$ trustees can "use, sell, or lease" the bankruptcy estate's property only "after notice and a hearing." 430 Relief from the automatic stay may be granted "after notice and a hearing" "for cause, including lack of adequate protection of an interest," or a finding that the "property is not necessary for an effective reorganization." 431 "The court, after notice and a hearing, may authorize the trustee to obtain" prioritized secured credit. ${ }^{432}$ The trustee "subject to the court's approval may assume or reject any executory contract or unexpired lease," and if the debtor has defaulted on the contract or lease, the trustee provides "adequate assurance of future performance under such contract or lease."433 The court must valuate collateral in order to determine the extent to which a debt is secured. ${ }^{434}$ The court must decide whether the claims of creditors are "substantially similar" to other claims of creditors in a putative class for a reorganization plan. ${ }^{435}$ The court must determine whether a disclosure statement for a plan consent contains "adequate information." 436 A plan may only be confirmed if the court finds that "confirmation of the plan is not likely to be followed by liquidation, or the need for further

\footnotetext{
${ }^{427}$ See Chic., Milwaukee, 791 F.2d at 528.

${ }^{428}$ Schwartz, supra note 337, at 187 . The following litany is drawn from Schwartz.

${ }^{429}$ See supra note 92.

${ }^{430} 11$ U.S.C. $\$ 363(b)(1)(2000)$.

431 11 U.S.C. $\$ 362(\mathrm{~d})(2000)$.

${ }^{432} 11$ U.S.C. $\$ 364(\mathrm{c})(2000)$.

43311 U.S.C. $\$ 365(a)-(b)(2000)$.

${ }^{434} 11$ U.S.C. $\$ 506(\mathrm{a})(2000)$.

${ }^{435} 11$ U.S.C. $\$ 1122$ (a) (2000).

${ }^{436} 11$ U.S.C. $\$ 1125(b)(2000)$.
} 
reorganization, of the debtor" - that is that the debtor is a viable entity going forward. ${ }^{437}$ These are hardly the only instances in which a court must exercise discretion in bankruptcy.

All of these instances call for an application of judgment by the court; there is already wide discretion invested in bankruptcy courts by the express provisions of the Code. These provisions should not be read as excluding other discretion, as in Chapter 11, a "party in interest, including the debtor, the trustee... [a] creditor...an equity security holder, or any indenture trustee, may raise and may appear and be heard on any issue in a case under this chapter.",438 Even for Chapters 7, 9, 12, and 13, these explicit Code provisions should be viewed as nothing more than the areas of necessary discretion that Congress could think of at the time of codification. Judging always involves some measure of discretion; the question is how it is to be channeled. Contrary to the usual cannons of statutory interpretation, the history and nature of bankruptcy law, including the presumption that " $[\mathrm{t}]$ he bankruptcy court will remain a court of equity" 439 urge for a reading of the Code as confirming specific discretionary powers, but not denying more general ones without explicit repudiation.

The "court of equity" tradition recognizes this. Equity could satisfy the practical demands of bankruptcy practice, but as noted above, it triggers a wariness or even hostility on the part of American courts ${ }^{440}$ and currently has questionable authorization if any. ${ }^{441}$ Federal common law involves less free-ranging discretion than equity and does not carry so much of the baggage of "judicial activism" because it is so firmly entrenched in our legal traditions—federal common law is channeled by precedent and judicially devised tests; not the span of the

\footnotetext{
${ }^{437} 11$ U.S.C. $\$ 1129(a)(11)(2000)$.

${ }^{438} 11$ U.S.C. $\$ 1109$ (b) (2000).

${ }^{439}$ H.R. REP. No. 95-595, at 359 (1977), reprinted as U.S.C.A.A.N. 5963, 6315.

${ }^{440}$ See supra section III.

${ }^{441}$ See supra section IV.B.
} 
Chancellor's proverbial foot. ${ }^{442}$ Federal common law is a better way to channel judicial discretion than the statutory language of section $105(\mathrm{a})$ or the pre-Code practices doctrine. Federal common law is flexible yet principled, unlike equity which is merely flexible. Moreover, there is solid authority for federal common lawmaking in bankruptcy - the unique federal interest because of the uniformity requirement of bankruptcy laws, Congressional authorization implicit in the Code, and the pre-Code practices doctrine.

Even courts that have limited bankruptcy equity through statutory language or judgemade tests recognize that there is something unique about bankruptcy that requires more discretion than other proceedings. The Fourth Circuit recognized this in a decision in the A.H. Robbins bankruptcy, when it allowed an injunction barring suits against non-debtor third-parties under the bankruptcy court's section 105(a) powers. There was no explicit statutory authorization for such an injunction, but it was upheld because, among other factors, "it was 'essential' to the plan" and "the entire reorganization hing[ed] on [it]."443 Likewise, in Dow Corning, the Sixth Circuit acknowledged that "the bankruptcy court, as a forum for resolving large and complex mass litigations, has substantial power to reorder-creditor debtor relations needed to achieve a successful reorganization." ${ }^{444}$ In essence, the Sixth Circuit articulated a different doctrine of necessity - that without broad discretion bankruptcy courts are incapable of untangling the Gordian knot of creditor-debtor relations and shepherding complex corporate reorganizations to successful conclusions for the general benefit. A rigid adherence to the Code is simply impractical in bankruptcy law.

Given the fact intensive nature of bankruptcy, Congress cannot possibly envision all of

\footnotetext{
${ }^{442}$ See supra note 244.

${ }^{443}$ Am. Hardwoods, 885 F.2d at 626 (citing In re A.H. Robbins Co. (Menard-Sanford v. Mabey), 880 F.2d 694 (4th Cir. 1989)).

${ }^{444}$ In re Dow Corning Corp., 280 F.3d at 656.
}

(C) 2006, Adam J. Levitin 
the unusual situations that might arise under the Code. Courts have institutional advantages in lawmaking. ${ }^{445}$ This is especially true for specialized courts like bankruptcy courts that have expertise in a technical topic like corporate reorganization. Thus, federal common law now tempers the rigidity of the Code, just as equity once tempered the rigidity of English common law. Federal common lawmaking, within the confines of the Code, ensures that Congress's policy intent is served and not shackled by Congress' choice of language.

To the extent that courts go too far in making federal common law in bankruptcy, Congress can override their rulings by amending the Code. As Judge Henry Friendly argued, federal common law:

permits overworked federal legislators, who must vote with one eye on the clock and the other on the next election, so easily to transfer a part of their load to federal judges, who have time for reflection and freedom from fear as to tenure and are ready, even eager, to resume their historic law-making function-with Congress always able to set matters right if they go too far off the desired beam. ${ }^{446}$

Indeed, as a positive matter, federal common lawmaking is what federal courts have been doing in bankruptcy for over a century. Congress has yet to raise objections. It certainly had the opportunity to do so when adopting the Bankruptcy Code, but instead chose to invest bankruptcy courts with wide discretion.

The exercise of lawmaking power by bankruptcy courts is consistent with the post-New Deal system of administrative agencies exercising tremendous lawmaking power through rulemaking and adjudications. Bankruptcy is the only major, Code-based legal regime in the United States for which there is no federal agency responsible for its implementation. ${ }^{447}$ Instead, in

\footnotetext{
${ }^{445}$ Field, supra note 73, at 934.

${ }^{446}$ Henry Friendly, In Praise of Erie-and of the New Federal Common Law, 39 N.Y.U. L. REV. 383, 419 (1964). See also Henry Friendly, The Gap in Lawmaking-Judges Who Can't and Legislators Who Won't, 63 CoLuM. L. REV. 787 (1963).

447 See supra text between notes 188 and 189.
}

(C) 2006, Adam J. Levitin 
bankruptcy, the courts play the role that agencies fill in other areas of law. Although bankruptcy proceedings are not governed by the Administrative Procedure Act, ${ }^{448}$ bankruptcy judges bring to bear the same sort of technical expertise that agencies do when engaged in rule-making. Viewing bankruptcy judges as an analog to agencies takes into account the technical, specialized, fact-specific nature of bankruptcy and also makes sense of the non-Article III status of bankruptcy judges. While bankruptcy judges are appointed and subject to removal by the Courts of Appeals for the circuits in which they serve, ${ }^{449}$ their bankruptcy judge's non-Article III status lessens separation of powers concerns, as their powers are not an aggrandizement of the judiciary at the expense of Congress. Certainly if bankruptcy judges were appointed directly by Congress to exercise power under the Bankruptcy Clause, there would be no separation of powers concern.

Courts already regularly create non-Code rights in bankruptcy and create rules of decision to guide the granting of these rights. ${ }^{450}$ As a positive matter, federal common lawmaking is an important part of bankruptcy practice, but it masquerades under the guise of equity. As Scott Rosenberg has noted, "federal courts simply do not speak the language of federal common law in bankruptcy cases. ${ }^{, 451}$

As a normative matter, judicial lawmaking in bankruptcy should be called and analyzed in terms of federal common law, not equity. Federal common lawmaking is already occurring, but no one recognizes it as such. Courts seem to have some sense that equity is not the proper framework for their activities; instead, they produce a clunking common law without

\footnotetext{
4485 U.S.C. $\$ 551$ et. seq.

${ }^{449} 28$ U.S.C. $\$ 152(a),(\mathrm{e})$.

${ }^{450}$ See, e.g., Mirant, 296 B.R. 427, 429-30 (applying CoServ critical vendors test); CoServ, 273 B.R. at 498-99 (creating critical vendors test); In re Dow Corning Corp., 280 F.3d at 658 (creating a seven-factor test for a bankruptcy court's injunction of a non-consenting creditor's claims against a non-debtor); Genesis Health Ventures, 266 B.R. at 606 (adopting a five-factor test for third-party releases from Zenith Electronics, 241 B.R. at 110); In re Standard Brands Paint Co., 154 B.R. at 571 (applying D.C. Circuit Auto-Train test and Second Circuit Augie/Resitvo test for substantive consolidation).

${ }^{451}$ Scott A. Rosenberg, The Theory of Protective Jurisdiction, 57 N.Y.U. L. REV. 933, 982 (1982).
} 
acknowledging it. It is time to call the process what it is and let courts do what they are good at - developing common law. The vocabulary and the analytical framework need to be adjusted to match the actual judicial processes. At the very least, the term "equity," when used in the jurisdictional and court powers sense, as opposed to the specific provisions of the Code, should be understood as a term of art meaning "federal common lawmaking." Doing so will remove non-Code practices from the realm of rhetoric and let them be considered within the well-defined tradition of federal common law that adheres to precedent when applicable and provides certainty and rule of law along with flexibility to match new circumstances.

The mislabeling of federal common lawmaking as equity in bankruptcy has greatly colored courts approach to all actions authorized under the banner of equity, particularly nonCode practices. Federal common law provides the mechanism for balancing the serious and legitimate concerns posed by Grupo Mexicano about the exercise of equity powers with the arguments in favor of bankruptcy equity in Pepper v. Litton and Bildisco. Federal common law reconciles the concerns about unbridled judicial discretion with the arguments that bankruptcy equity is authorized, legally required, consistent with the nature of bankruptcy, practically necessary, and harmonious with the post-New Deal state's acceptance of agency rule-making power as consistent with the separation of powers doctrine.

Federal common lawmaking does so by channeling discretion into the multi-factored rules of decision that are so frequently the hallmark of common lawmaking. Even the most equitable of all bankruptcy practices, equitable subordination, has been shoehorned into a multifactor test. ${ }^{452}$ Common law tests limit judicial discretion while retaining the ability to adapt to

${ }^{452}$ See Brian Leepson, Note and Comment, A Case for the Use of a Broad Court Equity Power to Facilitate Chapter 11 Reorganization, 12 BANKR. DEV. J. 775, 802-803 n.186 (1996). Also Otero Mills, Inc. v. Sec. Bank \& Trust (In re Otero Mills, Inc.), 21 B.R. 777 (Bankr. D.N.M. 1982), aff'd 25 B.R. 1018 (Bankr. D.N.M. 1982); In re Auto-Train Corp., 810 F.2d 270 (D.C. Cir. 1987); In re Augie/Restivo 
new situations. Common law judging is familiar to judges and adds to legal certainty by treating likes alike while still being sensitive to factual distinctions between cases. It also acknowledges the importance of judicial expertise, particularly in a technical area like bankruptcy, and is part of the Article III judicial power in areas like bankruptcy that are "uniquely federal interests." Common law presents a moderate, middle-ground between unrestrained equity and unbending and outdated, opaque, or absent statutory terms.

A common law understanding of bankruptcy practices also indicates that there is a broad middle-ground between the proceduralist or law-and-economics approach to bankruptcy and the practicalist or traditional approach. ${ }^{453}$ A common law interpretation is much closer to the traditional practicalist emphasis on the uniqueness of every bankruptcy case and the factintensive nature of bankruptcy proceedings. Yet, a common law approach also presents more predictable application of judicial discretion making it possible for parties to factor in legal regimes into their behavior ex-ante, as the proceduralists would like.

Courts are equipped with the necessary tools for reconciling bankruptcy courts' status as "courts of equity" with the statutory terms of the Bankruptcy Code. They already use federal common law to do so; it is only the conceptualization and the vocabulary that is absent. It is well time to reconsider these absences and to view non-Code practices in terms of federal common lawmaking rather than equity. Doing so will allow courts to avoid choosing between the poles of rigid, robotic application of the Code and unpredictable, unprincipled discretion and should result in more sensible rulings on pre-Code practices.

Baking Co., Ltd., 860 F.2d 515 (2d Cir. 1988).

${ }^{453}$ See supra text accompanying notes 14-23.

(C) 2006, Adam J. Levitin 